Portland State University

PDXScholar

5-7-1998

High Desert Homesteader: Alice Day Pratt, A Single Woman in Post, Oregon

Cathleen Croghan Alzner

Portland State University

Follow this and additional works at: https://pdxscholar.library.pdx.edu/open_access_etds

Part of the Women's History Commons

Let us know how access to this document benefits you.

Recommended Citation

Alzner, Cathleen Croghan, "High Desert Homesteader: Alice Day Pratt, A Single Woman in Post, Oregon" (1998). Dissertations and Theses. Paper 5835.

https://doi.org/10.15760/etd.7706

This Thesis is brought to you for free and open access. It has been accepted for inclusion in Dissertations and Theses by an authorized administrator of PDXScholar. Please contact us if we can make this document more accessible: pdxscholar@pdx.edu. 


\section{THESIS APPROVAL}

The abstract and thesis of Cathleen Croghan Alzner for the Master of Arts in History were presented May 7, 1998, and accepted by the thesis committee and the department.

COMMITTEE APPROVALS:

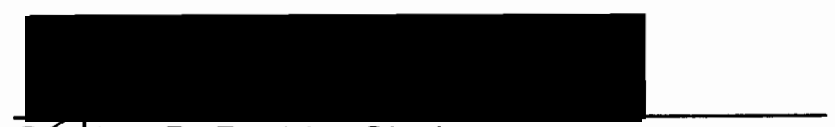

Gordon B. Dodds, Chair

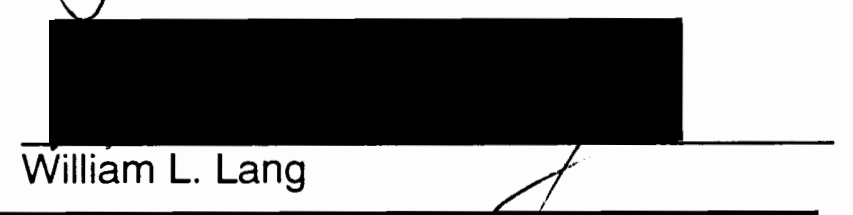

Johanna Brenner

Representative of the Office of Graduate Studies

DEPARTMENT APPROVAL:

GQrdon B. Dodds, Chair

Department of History 


\section{ABSTRACT}

An abstract of the thesis of Cathleen Croghan Alzner for the Master of Arts in History presented on May 7, 1998.

Title: High Desert Homesteader: Alice Day Pratt, A Single Woman in Post, Oregon

It is important to recognize the role of women in the development of the Trans-Mississippi West. Of the thousands of homesteaders, a significant percentage were single women. While a few historians have documented women homesteaders on the Great Plains, there is little information about those in the Pacific Northwest, particularly Oregon. The efforts of homesteaders who came to Central Oregon at the beginning of the twentieth century provide valuable information about the development of the region.

The purpose of this study is to document the homesteading efforts of Alice Day Pratt, a single woman and teacher. It attempts to put her into the larger historical context of gender roles and the agricultural development of the west. This study investigates the reasons why women would want to homestead and how successful they were. It also examines the realities of homesteading the High Desert region of Central Oregon. It details Alice's life, focusing upon the eighteen years she farmed and raised dairy cattle and chickens on the homestead she named Broadview. 
HIGH DESERT HOMESTEADER:

ALICE DAY PRATT, A SINGLE WOMAN IN POST, OREGON

by

CATHLEEN CROGHAN ALZNER

A thesis submitted in partial fulfillment of the requirements for the degree of

MASTER OF ARTS

in

HISTORY

Portland State University

1998 
To my independent-minded daughters

Angela and Maria

May you always lead interesting lives 


\section{ACKNOWLEDGEMENTS}

I am indebted to two outstanding professors of history at Portland State University, Dr. Gordon B. Dodds, my mentor and graduate advisor, and Dr. William L. Lang. They provided educational experiences that both challenged and encouraged me.

This thesis could not have been written without the help of Alice's nephews, Walden Pratt and William Pratt. Both shared with me invaluable insight and information about their Aunt Alice.

A special thank you must go to Jerry and Eloise Brummer of Prineville. They took me under their wing, invited me to stay at their home, and introduced me to Prineville residents who knew Alice. They answered my numerous questions about the Post-Prineville area; took me to Broadview; and introduced me to the beauty of this sage brush country. 
Dedication

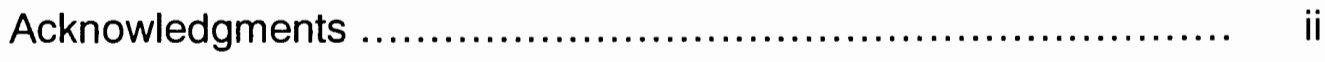

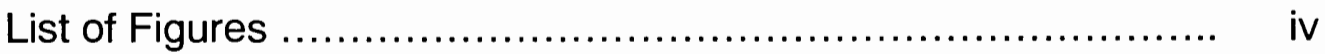

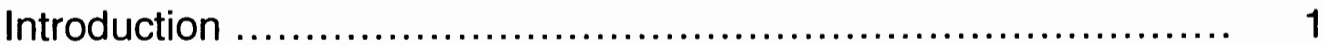

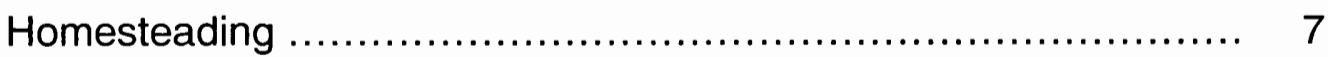

Women Homesteaders: Why Do It Alone? ........................ 34

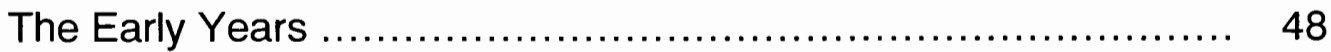

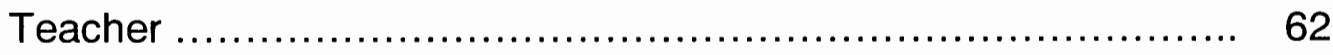

Homesteader .................................................. $\quad 75$

Life After Broadview ............................................... 131

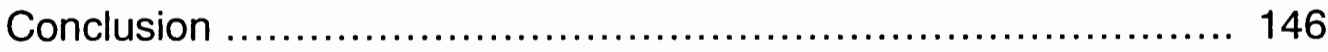

Bibliography ................................................... 149 


\section{LIST OF FIGURES}

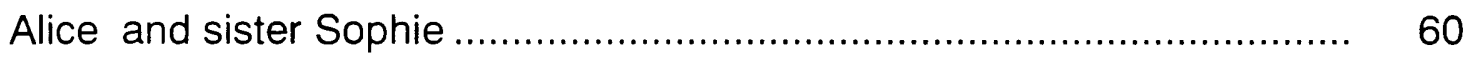

Alice in North Carolina ........................................................................ 73

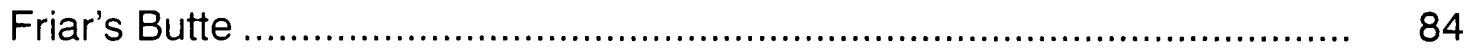

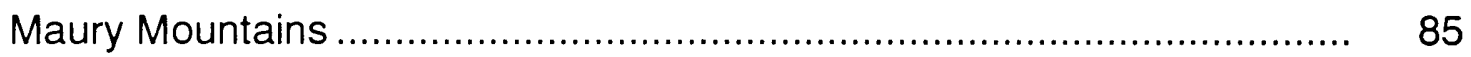

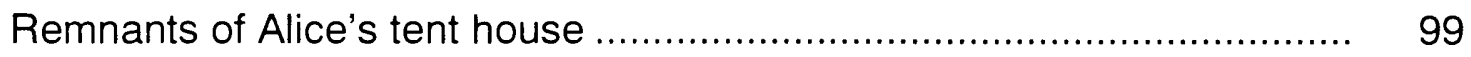

Remains of Alice's house ................................................................ 100

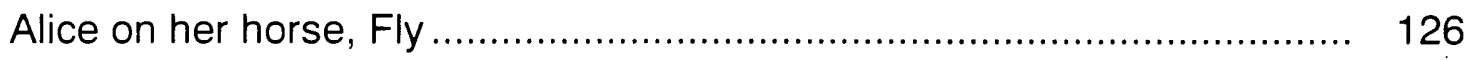

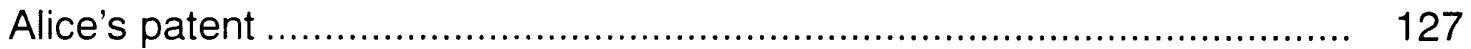

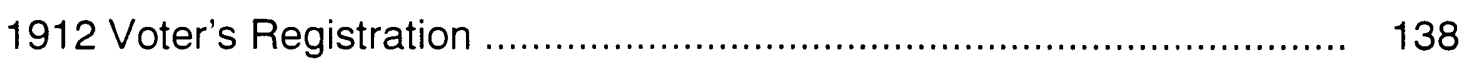

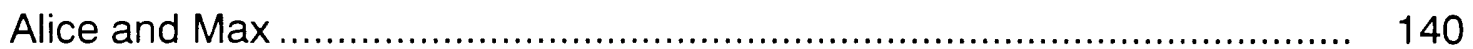

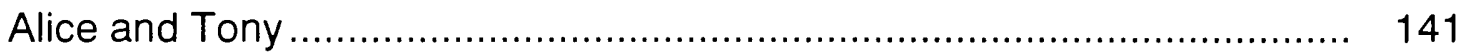

Marjorie, Alice, Julius, and Sophie ................................................. 142 
The government bets you 160 acres against $\$ 18.00$ that you'd starve to death before you lived on the land five years. ${ }^{1}$

Alice Day Pratt was a single homesteader in the harsh high desert of Central Oregon. She was an unmarried teacher who succumbed to "the longing and ambition -- innate but hitherto suppressed -- to own a portion of the earth's crust in my own right and to tamper with it unrestrained."2 Arriving at her claim on 21 June 1912, at the age of forty, she farmed until the end of 1930 when the combination of a dry rainfall cycle and the Great Depression forced her to leave her beloved Broadview and return east to New York. Her writings, A Homesteader's Portfolio and Three Frontiers, testify to the hardships and joys of homesteading the high desert of Oregon and the unique aspects of that experience encountered by single women.

Beginning in the late 1830s, the massive westward migration of thousands of Americans to the Trans-Mississippi West was, without a doubt, a watershed in American history. Pioneering women repeatedly are characterized as reluctant, tearful, obedient, and frightened wives who accompanied their husbands as they sought to fulfill their dreams. Customarily portrayed as "The Gentle Tamer" or "Brave Pioneer Mother," the stereotypical pioneer woman

${ }^{1}$ Sign at the prairie homestead of Ed and Alice Brown, Prairie Homestead National Historic Site, The Badlands National Park, Interior, South Dakota.

${ }^{2}$ Alice Day Pratt, A Homesteader's Portfolio, with an Introduction by Molly Gloss (Corvallis: Oregon State University Press, 1993, orig., NY: Macmillian, 1922), 2. 
strove to civilize the West, recreating the culture and refinements of her former home in the East by enforcing cleanliness, religion, law, and order. ${ }^{3}$

A contrasting and yet prevalent image of Western women is that of the prostitute, the "magdalen," whose strong, unconventional comportment was outside the boundaries of femininity. She "drank, smoked, and cursed and was handy with a poker deck, a six-gun, and a horse. ${ }^{14}$ She was portrayed as the antithesis of virtue and womanly decorum. She had no place within the Victorian definition of female nature of respectability; they were unrefined and lacked delicacy. Whereas the "Gentle Tamer" evokes positive notions of the West, the prostitute reinforces the negative images of a raw, rough, lawless West.

It is unfortunate that these two clichéd images are so pervasive in defining the popular perception of the West. Both are based upon fact, but the clichéd images neglect those who do not fit these two popular ideas. Of the tens of thousands of western homesteaders, single women may have comprised as many as one third. ${ }^{5}$ Although characterized as "societal misfits," or women

\footnotetext{
${ }^{3}$ Sandra L. Meyers, Westering Women and the Frontier Experience 1800-1915 (Albuquerque: University of New Mexico Press, 1982), 3.

${ }^{4}$ Meyers, Westering Women, 4.

${ }^{5}$ Percentages vary with the area and study. Mary W.M. Hargraves, "Women in the Agricultural Settlement of the Northern Plains," in Agricultural History 50 (Jan. 1974) p. 82 stated one estimate of land held in the Dakotas in 1887 was as high as one-third. Anne B. Webb, "Minnesota Women Homesteaders: 1863-1889," in Journal of Social History 23 (1 Fall 1989) p. 115, estimated there were 2400 women homesteaders during the period of her study. Oregon author Molly Gloss, who wrote the introduction to A Homesteader's Portfolio, cited studies of Colorado and Wyoming reported by Sheryll Patterson-Black and Gene Black in Western Women in History and Literature (Crawford, Nebraska: Cottonwood Press, 1978). Percentages of single women homestead entrants varied from 4.8 percent to 18.2 percent, the average being 11.9 percent. Gloss noted that estimates are as high as 30 percent of Western lands may have been held by women.
} 
who "couldn't get a husband," many single female homesteaders considered homesteading and land ownership a means to gain economic independence and rights. Land was an investment, a commodity to develop and sell. Many women perceived homesteading as an opportunity for greater autonomy. ${ }^{6}$ Some women could not tolerate passivity and submission, the social requisites of female behavior in Victorian era society. Anne Webb's data on Minnesota homesteaders revealed that women who owned land had the economic means to choose whether or not they wanted to marry. They were capable women, determined to be financially independent and make it on their own. ${ }^{7}$ "Like her married sisters, the single frontierswoman was a highly skilled laborer whose contributions to the frontier economy were vital to its progress. ${ }^{18}$ Edith Eudora Ammons Kohl and her sister Ida Mary are examples of these women. Since there was no postal service on the Lower Brulé (Oklahoma), they petitioned for a post office. Ida Mary became the first woman to run a post office on an Indian reservation. To transport the mail, they bought a team of horses and began hauling mail to and from the stage line. The post office became the center of town, a place to exchange news and ideas, and

\footnotetext{
${ }^{6}$ For further information on Western women see Mary Hargraves; "Women in the Agricultural Settlement of the Northern Plains," in Agricultural History 50 (Jan. 1974), 179-189; Glenda Riley, introduction to Land of the Burnt Thigh, (St. Paul: Minnesota Historical society Press, 1986); Glenda Riley, "Images of the Frontierswoman: lowa as a Case Study," in Western Historical Quarterly 8 (April, 1977), 189-202; June Sochen, "Frontier Women: A Model for All Women?" in South Dakota History 7 (1976), 37-60, .

${ }^{7}$ Anne B. Webb, "Forgotten Persephones: Women Farmers on the Frontier," in Minnesota History 50 (Winter 1986), 128. In a lecture given to Dr. Gordon Dodds' Pacific Northwest History class at Portland State University on 20 May 1996, Molly Gloss commented on the success of women homesteaders. She stated that nationally, 37 percent of men proved up their claims while 43 percent of women were successful.
} 
have one's problems solved. In addition to the post office, the two women ran

a grocery store and an Indian trading post. Edith edited the local newspaper,

The Wand, which became "the voice of the people, a voice heard across the prairie, across the Land of the Burnt Thigh, across the continent to the doors of Congress itself." 9

These adventurous western women's searches for independence were not a new phenomenon. The quest for female autonomy and independence can be traced back to days of the new American republic in the late eighteenth century but is most notable in the mid-nineteenth century. Victorian American society embraced the "Cult of Domesticity," a social construction of behavior which emphasized piety, purity, subjugation, motherhood, and home, the domestic sphere. ${ }^{10}$ The late 1830 s was a turning point in feminine behavior and attitudes; women were looking beyond the home and they began "to sense that they might shape that destiny with their own minds and

${ }^{8}$ Glenda Riley, "Farm Woman's Role in the Agricultural Development of South Dakota," South Dakota History 13 (1982), 98.

${ }^{9}$ Edith Eudora Kohl, Land of the Burnt Thigh, with an Introduction by Glenda Riley (St. Paul: Minnesota Historical Society Press, 1986, orig, Funk and Wagnalls, Inc., 1938), 286.

${ }^{10}$ Industrialization and the rise of the middle class transformed the concept of the family and the home became a refuge from the ills and corruptions of urbanization and industrialization. Women, as wives and mothers, were empowered as the redeemers of society and the upholders of religion and virtue. The "True Woman" possessed four cardinal virtues, submissiveness, domesticity, purity, and piety. Marriage, motherhood, and domestic sacrifice, all feminine qualities, epitomized domesticity and womanhood. Catharine Beecher, one of the first and most prominent architects of domesticity helped to establish a new domestic code which elevated women's position within the home and defined personal goals as unnatural and selfish. The terms "Cult of Domesticity" and the "Cult of True Womanhood" both refer to the same social construct. For further information see Katherine Kish Sklar, Catharine Beecher: A Study in Domesticity (New Haven: Yale University Press, 1973); Barbara Welter, "The Cult of True Womanhood: 1820-1860," in American Quarterly 18 (1966): 151-74; Stephanie Coontz, The Social Origins of Private Life: A History of American Families 1600-1900, (NY: Verso, 1988); Nancy F. Cott, The Bonds of Womanhood: "Woman's Sphere in New England 1780-1835 (New Haven: Yale University Press, 1977). 
hands."11 Called "strong minded women" by their more traditional counterparts, they sought opportunities outside of the home. ${ }^{12}$ Industrialization lured numerous rural women who moved to cities and joined their urban sisters as "mill girls" in the flourishing textile factories where they reaped economic rewards and social opportunities. Though they were unable to vote, "mill girls" in Lowell, Massachusetts eagerly attended political speeches and wrote commentaries for the newspapers they edited. ${ }^{13}$

Teaching, the only profession available to antebellum women, was an acceptable way for women to fulfill the stereotype of the ideal woman and to achieve their goals of independence, self-realization, empowerment, and mobility.

By using the teaching profession as their route to new lives, they achieved a significant degree of autonomy. Because teaching was an acceptable profession for women, they were able to attain a higher level of self-sufficiency than practically any other group of

\footnotetext{
${ }^{11}$ Nancy F. Cott, The Bonds of Womanhood: "Woman's Sphere in New England 17801835 (New Haven: Yale University Press, 1977), 125.

${ }_{12}$ Glenda Riley, Frontierswomen: The lowa Experience (Ames: lowa State University Press, 1981), 136.

${ }^{13}$ Although mill jobs attracted numerous women, and many did have a greater degree of independence and financial gain, the life frequently was bleak. The work was dangerous and mill owners, responding to competition from new factories, increased the amount of work and speed at which it was to be accomplished. Women commonly worked fourteen hour days six days per week. During the summer, they rose at 4:30 and began work at 4:50. Their lives were regulated by company rules and by bells, whose ringing told them what time to get up, to eat each meal, to be at work, and to go to bed, quite different from the less structured life of agriculture. They lived in mill owned boarding houses where they ate their meals. See National Park Service, Lowell: The Story of an Industrial City, (Washington DC: Division of Publications National Park Service, 1992); Shirley Marchalonis, The Worlds of Lucy Larcom, 1824-1893 (Athens: The University of Georgia Press, 1989); Edith Abbott, "Rules of the Mill: Lowell and Lancaster, 1820-1840," Harriet Farley, "A Letter from Lowell," and "Spirit of Protest" in Early American Women: A Documentary History 1600-1900, Nancy Woloch, ed. (Belmont, California: Wadsworth Publishing Company), 242-252; Mary H. Blewett, "The Sexual Division of Labor and the Artisan Tradition," in Women's America: Refocusing the Past, $3^{\text {rd }}$ ed., Linda K. Kerber and Jane Sherron De Hart, eds. (New York: Oxford University Press, 1991), 164-170.
} 
women in their time, almost unnoticed. By acting to take control over their own lives, they exhibited an independence of spirit. ${ }^{14}$

Civic leaders in new Western communities knew that school teachers not only educated their children, but that schools also enhanced the town's status and made them appear more respectable to new settlers. ${ }^{15}$ In a movement that began prior to the Civil War and continued into the twentieth century, thousands of young women left eastern seminaries and academies to teach in schools "out West." ${ }^{16}$ Alice, like many other women homesteaders, was a teacher. The money earned from teaching helped to finance their homesteads. At first, women frequently relied upon hired help, believing they lacked physical strength necessary for the initial arduous work of plowing sod, digging wells, and constructing houses.

Women homesteaders benefited from the social pioneering efforts of their "strong minded" predecessors: the competent and confident republican woman, the educated westward traveling teacher, 1848 feminists at Seneca Falls, antebellum abolitionists, and the progressive era reformers and radicals. As societal attitudes liberalized in the later nineteenth and early twentieth centuries, these women were not criticized as societal misfits, although many still considered them curiosities. Alice Day Pratt, teacher, writer, and single woman homesteader, is one of many women whose contribution to the development of the West and to women's place in society is often overlooked.

${ }^{14}$ Polly Welts Kaufman, Women Teachers on the Frontier (New Haven: Yale University Press, 1984), 48.

${ }^{15}$ Kaufman, Women Teachers, xix.

${ }^{16}$ Kaufman, Women Teachers, xviii. 
Chapter I

\section{HOMESTEADING}

Here nature opens her broad lap to receive the perpetual accession of new comers, and to supply them with food. I am sure I cannot be called a partial American when I say, that the spectacle afforded by these pleasing scenes must be more entertaining, and more philosophical than that which arises from beholding the musty ruins of Rome. ${ }^{17}$

My father, when I was young, said, "Reuben, my boy, when you grow up, get land. God has quit making land, but He keeps right on making people."

The image of the independent, self-reliant yeoman farmer, symbolic of an American ideal of a simple and virtuous life, persisted to the end of the nineteenth century. ${ }^{19}$ "Beginning in Jefferson's time, the cardinal image of American aspirations was a rural landscape, a well-ordered green garden magnified to continental size." 20 Thomas Jefferson expounded upon the virtues of an agriculturally based society. Comparing working in manufacturing with farming, Jefferson wrote in Notes on Virginia, "those who labour in the earth are the chosen people of God, if ever he had a chosen people, whose breasts he has made his peculiar deposit for substantial and genuine virtue." He continued, stating: "Corruption of morals in the mass of cultivators is a phænomenon of which no ages nor nation has furnished an

${ }^{17}$ St. John de Crèvecoeur, Letters from an American Farmer in Virgin Land, Henry Nash Smith (Cambridge: Harvard University Press, 1978), 121.

${ }^{18}$ E.R. Jackman and R.A. Long, The Oregon Desert (Caldwell, ID.: The Claxton Printers, Ltd, 1971), 381.

${ }^{19}$ This is the most common ideal, but, according to Henry Nash Smith, there actually were two mythical images: the southern plantation slave system and the northwestern garden headed by the yeoman farmer. Henry Nash Smith, Virgin Land: The American West as Symbol and Myth (Cambridge: Harvard Univeristy Press, 1978), 133. 
example." ${ }^{21}$ This passage has been used to romanticize and promulgate the virtues of an agrarian lifestyle. Although Jefferson actually is stating his preference, that agriculture is preferable to manufacturing, he acknowledged the importance of developing manufacturing so Americans would not be dependent upon Europe. What developed from Jefferson's statement, however, was a myth of rural virtue, that farmers were the most virtuous of men, which would be repeated by notables such as Benjamin Franklin, St. John de Crèveoeur, Stephen A. Douglas, William Gilpin, Andrew Johnson, Walt Whitman and poet James K. Paulding. ${ }^{22}$ "As Alexis de Toqueville noted, the wilderness was precious to Americans chiefly for what could be made of it -- a terrain of rural peace and happiness." 23

From the country's beginnings in the early seventeenth century, Americans moved westward in search of more and better land, land to be theirs alone, land that will sustain them and their families. Starting at the Atlantic seaboard, Americans expanded to the Appalachians by the mid-eighteenth century and continued to infiltrate the Ohio Valley. During the mid nineteenth century, they began pushing westward to the Oregon Territory, Utah, and California. By the end of the nineteenth century they were heading north to Alaska, America's last frontier. Americans believed it was their Manifest Destiny to settle the

${ }^{20}$ Leo Marx, The Machine in the Garden: Technology and the Pastoral Ideal in America (New York: Oxford University Press, 1964), 141.

${ }^{21}$ Marx, Machine, 124-5.

${ }^{22}$ Smith, Virgin Land, 33-46, 136-39, 284fn.

${ }^{23}$ Marx, Machine, 142. 
lands from the Atlantic to the Pacific. ${ }^{24}$ Even today, in this high-tech age where 74 percent of Americans reside in urban centers ${ }^{25}$ and many of the remaining farms are owned by large agribusinesses, people still desire to own some land of their own. The size of one's land may vary from a small backyard in an urban rowhouse to a suburban lot of a few acres.

Nevertheless, one owns a piece of property which (theoretically) is forever.

The United States has implemented and perpetuated pioneer land acquisitions. Where sovereignty was tenuous, the American government applied the same principle that Great Britain employed against Spain during the Nootka controversy of 1790 ; the factor determining sovereignty is land occupation, not exploration or rites of taking possession. ${ }^{26}$ Congress enacted laws that enabled settlers to acquire land for little or no fee. These included the Ordinances of 1785 and 1787 which provided for survey and land sales in the territories; the Land Law of 1820 which allowed the sale of tracts as small as one-quarter section for $\$ 1.25$; the Preemption Land Law (1841) giving

${ }^{24}$ Manifest Destiny refers to U.S. expansion policies. William Coleman, editor of the New York Evening Post, in 1803 stated that the "regulation of the 'destiny of North America belongs of right to the United States."' (p. 12) The term "Manifest Destiny" first appeared in the mid-1840s and meant "expansion, prearranged by Heaven, over an area not clearly defined." (p.24). For a more complete analysis, see Frederick Merk, Manifest Destiny and Mission in American History, with a Forward by John Mack Faragher (Cambridge: Harvard University Press, 1995).

${ }^{25}$ U.S. Department of Commerce, 1990 Census of Population: General Characteristics (Washington DC: U.S. Government Printing Office, June 1992), table 1, p.1. The total population in the United States in 1990 was $248,709,873$ of whom $187,053,487$ live in urban areas and 61,656,386 are rural residents. U.S. Department of Commerce, 1990 Census of Population: General Characteristics of Oregon (Washington DC: U.S. Government Printing Office, June 1992), table 1, p.1. The total population of Oregon in 1990 was 2,843,321 of whom 2,003,271 (70.4 percent) are urban dwellers and 839,050 reside in rural areas. 
"squatters" a way to receive legal title to land; the Florida Act (1842) which rewarded settlers with free land if they agreed to bear arms against Native Americans; and the Oregon Donation Land Law of 1850 which rewarded settlers of the Oregon Territory with free land. The later was responsible for the migration of approximately 30,000 settlers between 1842 and 1855 . The Florida Act and the Oregon Donation Land Law were important to the settlement of the United States, particularly the West. The Florida Act set a precedent for governmental distribution of free land while the Oregon Law granted a wife the right to hold land "in her own right." Both laws encouraged American settlement and therefore helped establish sovereignty, however, each was limited to a small geographical area: Florida Territory and the Willamette Valley. It would be 1862, twelve years after the Oregon Donation Act, before Americans would again have the opportunity to obtain free land.

Between 1856 and 1862, the concept of free land for settlers was hotly debated for a number of reasons. Labor proponents, in an effort to oppose monopolies by land speculators, argued that cultivation of one's own land was the only valid "currency". Republicans venerated the middle class and free enterprise. To them, the successful laborer was one who became selfemployed by owning capital - a farm, business, or shop. Their answer to urban poverty was "westward migration of the poor, aided by a homestead

${ }^{26}$ Dorothy O. Johansen, "The Role of Land Laws in the Settlement of Oregon," in Genealogical Material in Oregon Land Claims Vol. I (Portland: Genealogical Forum, 1957), n.p. 
act." ${ }^{27}$ Thaddeus Stevens, Congressman from Pennsylvania and one of the founders of the Republican Party, stated, "'The middling classes who own soil and work it with their own hands are the main support of every free government." 28 In 1860, the Republicans used the idea of a homestead law to entice Northwestern farmers and oppose the extension of slavery into new territories. To them, slavery degraded the concept of free labor and if it was allowed into the new territories, Republicans believed free labor would diminish as servile labor flourished. ${ }^{29}$ "The strongest appeal of the homestead system to the West, an appeal which touched the deepest levels of American experience in the nineteenth century, lay in the belief that it would enact the fee-simple empire, the agrarian utopia of hardy virtuous yeomen which had haunted the imaginations of writers about the West since the time of Crèvecoeur." ${ }^{130}$ Agrarian tradition and antislavery doctrine became entwined. An advocate of the Homestead measure, Representative George W. Julian of Indiana, in 1851 declared the ideal society as: "'The distribution of landed property, and its cultivation by freeman (sic). ${ }^{\prime \prime 31}$ Some landowners were fearful this meant a redistribution of land and a diminution of their property. Passage of the Homestead Act, according to its proponents, would not bring down the

${ }^{27}$ Eric Foner, Free Soil, Free Labor, Free Men: The Ideology of the Republican Party Before the Civil War (NY: Oxford University Press, 1970), 27.

${ }^{28}$ Foner, 17.

${ }^{29}$ Foner, 58.

${ }^{30}$ Smith, Virgin Land, 170.

${ }^{31}$ Smith, Virgin Land, 173. 
high by taking land away from them, but instead, would bring up the lowly by making public land available for their ownership. ${ }^{32}$

\section{HOMESTEAD ACTS}

Signed by President Abraham Lincoln on 20 May 1862, the Homestead Act (passed on 17 May 1862) stated: "...any person who is the head of a family, or who has arrived at the age of twenty-one years, and is a citizen of the United States, or who shall have filed his declaration of intentions to become such, as required by naturalization laws of the United States Government...shall be entitled to one quarter section." ${ }^{133}$

The use of the term person is significant because it granted women having no husband the right to own land in their own names. ${ }^{34}$ Conditions of the act required the applicant to make improvements ("prove up") upon the land, which included building a shelter and improving the land by farming or raising livestock. An individual had to live in the shelter and could be absent not longer than six months in any given time. If these requirements were fulfilled within five years from the date of application, the homesteader received a patent (title) to the land. While the land itself was free, a settler did incur certain fees associated with public land transactions. The filing fee for 160 acres was $\$ 10.00$, a commission fee of $\$ 4.00$ was payable at the time of

${ }^{32}$ Foner, 29.

${ }^{33}$ A quarter section is 160 acres.

${ }^{34}$ This was not the first time women in the Pacific Northwest were able to claim land in their own name but it was the first time they were able to do so nationally. The Oregon Donation Land Act of 1850 also allowed a woman to claim land in her own name. 
filing, and, again, when the final proof was made. ${ }^{35}$ Filers could purchase their claim after six months, for $\$ 1.25$ per acre. Between 1862 and 1883 , 4,617 homesteaders proved up in Oregon.$^{36}$ Later homesteaders found the Homestead Act unsuitable for particular situations and it was revised several times. One revision, the Enlarged Homestead Act of 1909, allowed the homesteader to claim 320 acres in arid or semi-arid nonmineral, nontimbered areas. Another, in 1912, decreased the residency requirement from five to three years. ${ }^{37}$

Several events, including Frederick Jackson Turner's 1893 declaration that the frontier was closed, an economic downturn in 1907, the Enlarged Homestead Act of 1909, and the invention and promotion of dry land farming techniques spurred many people to obtain a part of their "birthright.."18 Between 1900 and 1920, more land was homesteaded than in the previous forty years. In 1904, ninety five percent of the United States was in the public

${ }^{35}$ Paul W. Gates, History of Public Land Law Development (Washington D.C.: Public Land Law Review Commission, 1968), 384.

${ }^{36}$ Jackman and Long, 49.

${ }^{37}$ Paula M. Bauman, "Single Women Homesteaders in Wyoming, 1880-1930," in Annals of Wyoming 58 (Spring 1986), 40, 41 and Jackman and Long, 49. Three other acts are the Desert Land Act (1891) which increased a claim to 320 acres but stipulated the land must be irrigated and produce a crop within three years, the Stockraising Homestead Act (1916) which enlarged holdings to 640 acres, and the Taylor Grazing Act (1934) which withdrew land from homesteading, thus reversing 150 years of public access to land.

${ }^{38}$ Turner's thesis, "The Significance of the Frontier in American History," was delivered to the annual meeting of the American Historical Association. Turner proposed that the frontier was where civilization and "savagery" met. As Americans moved westward, settled, and developed free land the frontier was diminished. By 1890 there were no more large areas of land for Americans to conquer. It is not known, however, how many homesteaders, if they had even heard of Turner's theory, were affected by it. Turner's thesis is Eurocentric, omits the contributions of women, and supports a rural agrarian lifestyle, but, for decades, it seriously influenced western history. 
domain but by 1915 more than ninety percent was claimed in accordance with one of the various homestead laws. ${ }^{39}$

\section{HOMESTEADING THE HIGH DESERT OF CENTRAL OREGON}

The "High Desert' region of Oregon was a calling card to those seeking land. As late as 1925, this region was called "the last homestead frontier in America." Its legacy, however, was one of "substantial failure." ${ }^{40}$ The statement, "God made the desert. Man, as yet, hasn't unmade it," sadly, for many eager homesteaders, became too true. ${ }^{41}$

Approximately one fourth of Oregon -- 24,000 square miles, the size of West Virginia -- is desert. It is a wide, high, sagebrush and juniper covered plateau between the Cascade Mountains on the West, the Blue Mountains on the East, the Shaniko region to the North and the Lake country to the South. It covers portions of four counties, Crook, Deschutes, Harney, and Lake. Huge geological faults, volcanoes, lava flows, and glaciers have created high rocky cliffs, rim rock, and lava plains. The elevation varies from 3,500 feet in the Deschutes River bed to 6,000 feet in some of the higher buttes. It is a triangular area bounded by the Cascades, the Maury Mountains, a group of disconnected hills in central Crook County south of Crooked River, and the Sagehen Hills. On a political map, this triangular area extends from Redmond

\footnotetext{
${ }^{39}$ Barbara Allen, Homesteading the High Desert, (Salt Lake City: University of Utah Press, 1987), 27

${ }^{40}$ Isaiah Bowman, The Pioneer Fringe, (Freeport, N.Y.: Books for Libraries Press, 1931, reprint 1971), 93.

41 Jackman and Long, 11.
} 
(Deschutes County), east to Burns (Harney County), and south to Fort Rock-Christmas Lake valley (Lake County). Here, the average elevation is 4,500 feet. This high elevation contributes to cool summer nights. Crop damaging frosts often begin in the early fall and continue into June. Winters are cold with frequent snow. In addition to the heat and cold, central Oregon is windy and the fertile soil is sandy.

While it is devoid of vegetation and animal life, the desert is host to numerous varieties of plants and animals. Most of the vegetation is gray: sagebrush, grass, saltbush, and weeds, as are the animals: coyotes, lizards, rattlesnakes, mice, gophers, jack rabbits, cougars, and deer. During the spring when the snow melts and there is enough moisture to sustain plants, the desert becomes a patchwork of color: primroses, buttercups, larkspur, phlox, and coral mallow. ${ }^{42}$ "The mystique of the desert, its hidden beauty, and the story of human struggle against adversity are understood only by those possessing a feel for the land." ${ }^{143}$

Writing in 1931, historian Isaiah Bowman noted four stages in the Euroamerican settlement of Central Oregon. The first, he called pre-railroad. During this stage, the ranching-farming combination dominated. Even though it was a great distance from the ranch to the railroad, cheap land and the relatively high price of grain and livestock made it profitable to graze the animals and drive them to shipping points. The second stage, Bowman noted,

${ }^{42}$ Brogan, p. 81-83, 267-276; Allen, 3-6; and Jackman and Long, 1-10. 
was marked by the notable increase of dry farming which occurred just before and after 1911, the year the railroad arrived in Bend. The third stage was characterized by the failure of dry farming except in the best locations and during the best years. During this stage, farmers and ranchers developed more exact methods suitable to the particular local climate and soil conditions, and the availability of mountain pastures. The fourth stage begins in 1915 when two large lumber companies arrived. Both began production in 1916. The lumber industry shored up Bend's economy as failing homesteaders turned to employment in the timber industry. Timber money and federal aid built thousands of dollars of market roads which brought in more work for locals and newcomers who would spend their money and build homes in the Bend area. ${ }^{44}$

Immigrants began arriving in the Oregon Territory via the Oregon Trail in 1839. By 1870 the choice land, the lush Willamette Valley in Oregon and the grass-covered rolling hills of the Palouse country in the northeastern corner of Washington and the Idaho panhandle, had already been claimed by farmers. The thin volcanic soil of the high, dry lands east of the Cascade Mountains was not well suited for subsistence farming but new immigrants discovered it was excellent for open-range sheep and cattle ranching. Fortunately for these

${ }^{43}$ Raymond R. Hatton, Pioneer Homesteaders of the Fort Rock Valley, (Portland: Binford and Mort: 1982), viii.

${ }^{44}$ Bowman, 102. The Ochoco Mountains northeast of Prineville, were noted early as a valuable source of timber. Entrepreneurs built small saw mills for local use beginning in the 1870s when Ike Swartz built on Mill Creek. C.C. Maling built one of the most important early mills in 1877 on Willow Creek east of present day Madras. Crook County Historical Society, The History of Crook County (Prineville, Or.: Crook County Historical Society, 1981), 25. 
newcomers, basic political and economic structures such as civil

government, roads, trade centers, and military protection, already were in place, the products of the placer-mine boom in Auburn, and along the John Day River. ${ }^{45}$ Like settlers everywhere, the first to arrive in a given area, farmers, cattlemen and sheep herders, chose sites along creeks and river basins with which they irrigated their farms and watered their livestock. ${ }^{46}$ Most of those seeking land had little money and if one wanted to take advantage of free land offered by the federal government, there was little choice but to stake a claim in desolate Central Oregon. Initially discouraged by the federal government because of problems between Indians and whites, few chose Central Oregon. To keep whites and Native Americans separate, Major General John E. Wool, commander of the Department of the Pacific, U.S. Army, issued an order in 1856 forbidding settlement east of the Cascades. ${ }^{47}$

\footnotetext{
${ }^{45}$ William H. Willingham, "Family and Community on the Eastern Oregon Frontier," Oregon Historical Quarterly 95 (Summer 1994), 177.

${ }^{46}$ Brogan, 82, 83, 96, 97.

${ }^{47}$ Brogan, 83. Although the Oregon Donation Land Act allowed people immediately to claim land, it made no provision for extinguishing Native American title to the land. This created tense Native American/white relations which were further aggravated by the influx of miners to southern Oregon. The cause of Wool's order was the Yakima War in 1855-6. Miners had been crossing Yakima land to the gold fields of Colville in Washington Territory. Although hundreds of miners traveled the route, two incidents occurred in which white men were killed. Wool was not overly concerned. The incident which ignited hostilities was the death of Andrew Bolon, 23 September 1855. In an attempt to prevent further bloodshed, Bolon went to the Yakima territory; however, he turned back on advice from Shumaway, an Indian with whom he had a good relationship. Shumaway told him Qualachan's band was "out for blood." Along the trail, Bolon met Shumaway's son, Moshell and some of his friends. Trusting them, Bolon rode towards The Dalles with them. Unfortunately, in an attempt to surpas Qualachan, Moshell murdered Bolon. Although Shumaway knew that the perpetrators should be turned over to the white authorities, he was afraid that they would be killed. White settlers insisted upon retaliation. The Pioneer and Democrat declared, "We trust they [the Yakimas] will be rubbed out - blotted from existence as a tribe."'(p. 241) Governor George Curry (Oregon) and Charles Mason, acting for Governor Issac Steven (Washington), who was in Blackfoot territory, called for civilian volunteers. The civilian troops
} 
Two years later, on 31 October 1858, General William S. Harney rescinded the order because it had become more difficult to keep whites out of the region than to control the Native Americans. ${ }^{48}$ Despite the revocation of the order, many people were fearful of Indian uprisings. The greatest hindrance to settlement, however, was the lack of good roads. Those that did exist were quite poor. The first settlers into what is now the Crook County region, the Scott family, did not arrive until 1863, but by $1911-1912$, the High Desert was well populated. Crook County reported 300 land filings on 96,000 acres by the first of May, $1930 .^{49}$

Homesteaders believed erroneous predictions that this area could become another wheat belt despite widespread knowledge that this is an arid region. The annual rainfall, eight to ten inches, either sinks into the ground or into alkali lakes which have no outlet. Streams and springs are the main source of water but many of these dry up in the summer heat, which occasionally is over 100 degrees (Fahrenheit). Higher than usual rainfall, approximately three inches above normal, from 1902 to 1912 bolstered optimism. During the years of peak settlement, 1912-1917, four of the six years had abundant rainfall and in the other two years, it was only slightly

confronted the Yakimas who fled. Instead of stopping, the civilians provoked other groups such as the Cayuse and Walla Wallas. They killed chief Peopeomoxmox, who had come bearing a white flag, and mutilated his body. The civilians continued to kill, loot Native American horses and eat their cattle. General Wool never favored the use of the militia and issued orders to Governor Curry against it. Governor Stevens praised the efforts of the civilians. Kent D. Richards, Issac Stevens: Young Man in a Hurry (Provo, UT: Bringham Young University Press, 1979), 235-256.

48 Brogan, 83. 
lower. In spite of this higher than normal rainfall, crops did not flourish. ${ }^{50}$

Even though dry farming was successful in Montana and eastern Washington, the High Desert was different. Snow capped mountains and reports of bunch grass "'as thick as a meadow"' covering basins and uplands led settlers to believe they could successfully grow grain.

Many honest, hard-working people lost years of their time at the hard labor, and all their capital, trying to make farms out of land that was entirely unsuited for it. Thousands of acres of the finest range were ruined for, when the sage brush and bunch grass were cleared off, and the land plowed, the wind blew enough of the top soil away so that the bunch grass would not grow again. All because officials in Washington, who knew nothing about the country, thought it was suitable for dry farming and would not listen to the advice of the old settlers who knew what they were talking about! ${ }^{51}$

Although lacking water for productive farms, this land was excellent for livestock. Ranchers were the first to settle this wide open land, grazing their animals on the unfenced public range, making Crook County one of the foremost stock regions in Oregon. In October 1884, the total assessed value of property in the county was $\$ 1,612,323$. Cattle, sheep, and horses, in equal proportions, accounted for one half of that amount. As farmers and ranchers prospered, Crook county became one of the wealthiest counties, per capita, in the state. ${ }^{52}$ Unfortunately, this wealth did not persist. A national economic

${ }^{49}$ Bowman, 98, Brogan, 83. At this time, Crook County included Deschutes County which was created on December 13, 1916.

${ }^{50}$ Bowman, 94 and Hatton, 31-32.

${ }^{51}$ Urling C. Coe, Frontier Doctor: Observations on Central Oregon and the Changing West, with an introduction by Robert Bunting (Corvallis: Oregon State University Press, 1996, orig., Macmillan Co., 1940), 236.

52 State of Oregon, An Illustrated History of Central Oregon Embracing Wasco, Sherman, Gillian, Wheeler, Crook, Lake, and Klamath Counties (Spokane, WA.: Western Historical Publishing Co., 1905), 712. 
depression in 1893 reduced agricultural prices which took almost the remainder of the decade to recover. ${ }^{53}$ Dry weather cycles destroyed crops. Cattlemen and sheep ranchers engaged in range wars, slaughtering thousands of animals, and sometimes other ranchers. Incoming settlers claimed land and built fences, eliminating hundreds of acres of open range land upon which livestock had grazed. Nevertheless, for years, cattle and sheep ranchers dominated. For hundreds of miles to the east and west of Bend "thousands upon thousands of wild range horses, cattle and sheep grazed on the open range year around." ${ }^{54}$ Cattle and sheep could be wintered in lower elevation basins and then, during the hot summers, they would be moved to higher pine covered valleys. Flora Beoletto Gillmor, whose Italian immigrant parents James and Ida Beoletto, homesteaded in Post, Oregon, recalled the necessity of raising cattle because one "couldn't make a living off homestead." Her parents, like other prosperous settlers, "made it from cattle." ${ }^{55}$ The Beolettos began in 1913 with 320 acres which they proved up, bought another 320 acres, and then began buying land during the dry years from those who had lost their land. In all, they bought eight other homesteads and forty acres from the State Land Board. By the time of his death, in 1935, James had increased the family's total land holdings to 2,440 acres. ${ }^{56}$

\footnotetext{
${ }^{53}$ Allen, 23.

${ }^{54}$ Coe, 4.

${ }^{55}$ Interview by author 20 July 1996 at the home of Mr. and Mrs. Jerry Brummer, Prineville, Oregon.

${ }^{56}$ Beverly Wolverton, A Hundred and Sixty Acres in the Sage: Homestead History of the Immediate Post Area (Post, Oregon: Beverly Wolverton, 1984), 44.
} 
At the beginning of the twentieth century, Prineville area cattlemen and sheep herders were embroiled in bitter range wars in which they slaughtered thousands of cattle and sheep and lynched and killed each other. Fiercely protective of their lifestyle, cattlemen organized The Crook County Sheep Shooters Association whose sworn goal was to rid the county of sheep men and prevent the arrival of new ones. Not only did they threaten sheep herders, but also informed the rest of the state not to meddle in their business. In a 29 December 1904 letter to The Oregonian, the Sheep Shooters proclaimed,

We claim to have the banner county of Oregon on the progressive lines of sheep-shooting and it is my pleasure to inform you that we have a little government of our own in Crook county, and we would thank the Oregonian and the governor to attend strictly to their business and not meddle with the settlement of the range question in our province. ${ }^{57}$

Urling Coe, a physician in Bend from $1905-1918$, saved the following newspaper clipping:

On the evening of February 3, 1904, five masked riders visited a corral on the Christmas Lake County in which a flock of 3,000 sheep owned by the Benham Brothers had been placed. A sack was placed over the head of the herder and he was forced to stand under a tree. With rifle, pistols, knives, and clubs, the masked men started the slaughter at dusk, and continued the work most of the night. The sheep stampeded and about 500 escaped, only to fall prey to coyotes. The herder was warned, and then turned loose. The sheep killers were never found but J.C. Conn of Silver Lake, who was believed to know who the masked riders were, was later found dead in a field with several bullets in his body. ${ }^{58}$

\footnotetext{
${ }^{57}$ State of Oregon, Illustrated History, 720.

${ }^{58}$ Coe, 5.
} 
A letter from Prineville appeared in a June 1904 issue of The Dalles Times-Mountaineer which described the first open slaughter of sheep in Crook County. ${ }^{59}$ The son of homesteader ranchers, Prineville resident, historian and author, Gale Ontko said his grandfather, Hank Cook, was shot in the back through the window by a person believed to be a "sheeper." According to local lore, one settler who was keeping supplies for a sheepman, "woke up one morning to find dead sheep at every fence post." Ontko believes that "much of the sheep killing was done by other sheepers and blamed on cattlemen." ${ }^{60}$ To this day, it is not known for certain who were the organizers and member of the Crook County Sheepshooters Association. ${ }^{61}$

Although intense, the range wars were short lived, and seem to have subsided in 1905. Stockmen initially opposed the formation of forest reserves, authorized by a law of 28 July 1902 . Accustomed to freely grazing their animals in forest pastures, the believed it "was their right to continue if the stock industry was to continue." The range wars denoted a need for some type of supervision of grazing. In an effort to prevent further violence, the federal government granted each rancher an allotment of land on which to graze their respective animals. On 11 April 1906, the forest supervisor at Prineville received a letter from the national forester in Washington, D.C. which delineated the provisions for grazing permits and allotments.

\footnotetext{
${ }^{59}$ State of Oregon, Illustrated History, 718.

${ }^{60}$ Interview by author, 21 July 1996 at the home of Gale Ontko, Prineville, Oregon.

${ }^{61}$ Brogan, 121.
} 
Although cattlemen resented the encroachment of sheep onto "their" land, the two groups had formed a truce. As the number of homesteaders significantly increased during the beginning of the twentieth century, cattlemen (and now sheepmen) found their way of life again threatened. Homesteaders carved out claims on public land which had been used for grazing land. They planted crops and built fences to keep out wandering livestock. Unfortunately, some of the stockmen so resented the homesteaders, they made little effort to keep their animals out of farmers' fields.

A critical problem for those residing in the High Desert was the lack of railroads. Livestock, wool, and grain had to go by wagon over poor roads to Portland via routes through the Cascade Mountains or through the Columbia gorge. These freighting trips could last as long as several weeks. Promises of railroads encouraged settlers but those promises were quite slow to materialize. By 1903, both Bend and Prineville had populations large enough to support a railroad and talks ensued but residents waited eight years before the Oregon Trunk Line was built between The Dalles, in the Columbia gorge, and Bend. "After being shunned by railroad builders for the better part of three decades, Central Oregon awoke to find herself the object of the affections of two intensely jealous suitors." 62 The two "suitors" were railroad magnates Edward Henry Harriman, chairman of the board of the Union Pacific Railroad (1898-1909) and "The Empire Builder," James Jerome Hill, who

${ }^{62}$ Carlos Schwantes, Railroad Signatures Across the Pacific Northwest (Seattle: Univeristy of Washington Press, 1993), 147. 
bought and reorganized the bankrupt Northern Pacific, and added it to his Great Northern system. On 23 August 1904, these two bitter rivals became engaged in a territorial war that was the "greatest burst to railroad building the Pacific Northwest had seen since the Great Northern was completed to Seattle in 1893." ${ }^{\circ 3}$ Speaking to an enthusiastic crowd at the Lewis and Clark Exposition in Portland, Hill received "'a mighty ovation," and told his audience he wanted to "help with the development of this great state."' The next day The Oregonian, reflecting local feelings, proclaimed, "'Oregon is at last free from the Harriman thraldom." 64 Harriman's Union Pacific controlled the Oregon Railway and Navigation (OR\&N) which ran along the south bank of the Columbia River, 'the Portland and Seattle Railroad, and he was well established in the Willamette Valley. Hill, who owned the Spokane, Portland and Seattle (SP\&S) argued that it would be less expensive to lay tracks along the north side of the Columbia. He planned on crossing the Columbia, following the Deschutes River to Bend and, later, south to Klamath Falls. Hill was aware of the interrelatedness of settlers and railroads. If they were prosperous, the railroad would be prosperous. He also understood the importance of developing Pacific Rim trade to balance the flow of goods between the East and the West. Hill envisioned products coming into Portland where they would be loaded onto (Hill owed) trans-Pacific freighters bound for China and Japan.

${ }^{63}$ Schwantes, 144 
In his attempt to enlarge his empire and surpass Harriman, Hill "assumed that he could make even this apparent desert [Central Oregon] 'bloom as the rose."'65 $\mathrm{He}$ acquired the projected but neglected Oregon Trunk Line along the Deschutes River and began purchasing key land parcels. When Harriman learned of Hill's maneuvers, he formed his own line, the Deschutes Railroad and a building frenzy began. The two rivals encountered a major problem at the narrow Deschutes Canyon: there was space for only one set of tracks and a contest ensued. Harriman, who was battling stomach cancer, died before the dispute was settled but his protégé, Robert Lovett, took up the crusade. Ultilmately, Hill and Lovett agreed to jointly finish the last fifty-three miles into Bend. Completed in October 1911, the Oregon Trunk Line, functioning as property of the SP\&S, crossed the Columbia at Wishram, Washington to The Dalles, Oregon, terminating in Bend. During the ceremony in Bend, at which the golden spike was driven in, Hill called the new rail line the "'Inside Gateway," and told the cheering crowd that Bend would now realize increased prosperity and a greater population. ${ }^{66}$ Once built, this rail line significantly improved the transportation of products to market and decreased the cost, thus making wheat farming more economically feasible and attractive to prospective farmers. ${ }^{67}$

\footnotetext{
${ }^{64}$ Michael Malone, James J. Hill: Empire Builder of the Northwest (Norman: Univeristy of Oklahoma Press, 1996), 236, 237.

${ }^{65}$ Malone, 239.

${ }^{66}$ Malone, 236-241. See John T. Gaertner, North Bank Road: The Spokane, Portland \& Seattle Railway (Pullman: Washington state University Press, 1990), 96-119.

${ }^{67}$ Allen, 92; Bowman, 96, 99.
} 
Encouraged by advertisements from the Union Pacific and Great Northern railroads and other "boosters" about the climate and the availability of good farmland, people sought claims in Oregon's high desert. Railroads offered reduced fares for those traveling to central Oregon. "Locators" set up offices in Bend, Prineville, and Lakeview offering as a benefit to the unknowing, their familiarity with the area. After listening to one locator at a stage stop between Shaniko and Bend, George Palmer Putnum made the following comment, "My informant was a professional 'locator' whose business it is to combine the landless man and the manless land with some profit to himself in the shape of a fee for showing each 'prospect' a suitable tract of untaken earth hitherto the property of Uncle Sam." ${ }^{68}$ Advertising their services in Eastern newspapers, locators "proved irresistible to schoolteachers, bank clerks, and others who believed in fairies." 69 Interestingly, locators charged a fee, from $\$ 30$ to $\$ 300$, which could be as much as half of naive prospective homesteaders' savings, to find them a piece of free land. ${ }^{70} \quad$ Locators and boosters also published locally. An ad in a 1909 number of the Silver Lake Leader (in the Christmas Valley area) stated: "'U. S. Dickey. We do a general locating business and can locate you on the choicest lands in the famous Fort Rock and Christmas Lake Valleys which is

\footnotetext{
${ }^{68}$ Allen, Homesteading, 38.

69 Jackman and Long, 49.

${ }^{70}$ Allen, 38.
} 
the coming wheat-producing section of Oregon. ${ }^{171}$ The Bend Commercial

Club promoted free land and the area's livability.

This land is FREE. Perpetual water rights cost $\$ 40$ an acre. Forty acres means independence, eighty acres brings wealth. From Bend settlers are located on 320 acre homesteads on the vast area of sage brush land to the southeast. Here is found the biggest and last chance for the land hungry to get free Government land that is worth the having... Bend is the most beautiful and healthful town in Central Oregon. It has a public water system, with absolutely pure water. It has electric lights, splendid schools, churches, a free library, hotels, banks, etc. ${ }^{72}$

A later ad in the Bend Bulletin contained the following statement:

Every issue of The Bulletin records the progress of Central Oregon and the Bend country. If you are a homeseeker looking for a new location, or own property in this section, there is no better way to become acquainted with, or keep posted on, what is being done in this part of the world than by reading this paper regularly. Send in your subscription at once, so as not to miss anything of what is going on in this big, resourceful country -- this great inland empire that has now been opened for development by two railroads. ${ }^{73}$

A 1912 article in the same newspaper, "Information for the Homeseeker," covered topics such as "The City Itself," "Railroads," "Irrigation," "Dry Farming," "Water Power," "Recreation," and "How to Get There." In an attempt to boost prospective homesteaders' confidence in their ability to make a successful life, the article made the following claims for the region:

A climate that is practically ideal... government records show an average annual precipitation of 16 inches with an average year of 320 sunny days. That means enough rain for the farmer, lots of blue sky and bright sunshine, no oppressive heat and climatic environment that gives Nature every possible chance to get the best results... In other words, Bend is well equipped, modern and progressive, with a lot of wide-awake men who have spent good money developing the town, and who are getting good returns on their investments... The soil and climate, however are particularly

\footnotetext{
${ }^{71}$ Allen, 39

72 Bend Bulletin, 25 Jan. 1911

${ }^{73}$ Bend Bulletin, 24 April 1912.
} 
adapted to the successful production of grasses and root crops... a man with forty acres who will raise grass and feed it to his cows will be assured of a comfortable living... Work is now in progress upon a great new irrigation canal... enormous timber belt... and the fare" from Portland "is $\$ 7.45$. $^{74}$

Lauding Oregon, one promotional book, published in Portland probably in the mid-1920s, stated: "The climate of Crook county is very healthful, free of malaria, fevers, plagues, locusts, potato bugs and fleas. ${ }^{75}$ It touted dairy farming and egg production, declaring that Oregon would become an egg exporting state that would supply its neighboring states. The potential economic benefits, it declared, were quite good with egg prices ranging from twenty five cents to sixty five cents per dozen in Portland and "in Eastern Oregon the cost of production is less, owning to almost perpetual sunshine and dry, mild climate..$^{76}$

Anticipating the Oregon Trunk Line, within a three month period from late 1910 to early 1911 , thirty homesteader cabins sprung up within a ten mile radius of Bend. The view was one of cleared land and home building. "It wasn't the Klondike 'rush' it was pictured to be - that is the booster's note; but it was a movement by scores and by hundreds." 77

Unfortunately, the booster literature was not always truthful. Not only were they overly optimistic about the climate and soil conditions, but they also failed to report the prevalence of coyotes which preyed on sheep and cattle,

\footnotetext{
${ }_{75}^{74}$ Bend Bulletin, 24 April 1912

${ }^{75}$ Advantages to Oregon: A Resource Book, (Portland: Brockman Brothers, n.d.), 120

${ }^{76}$ Advantages to Oregon, 22.
} 
and jack rabbits, sage rats (ground squirrels), and grasshoppers that were capable of totally destroying one's crop as well as stored grain. Jack rabbits ate flowers, kitchen gardens, grain crops, and alfalfa, which was a particular delicacy. After dining all summer on the tender green shoots, they would continue the feast into the winter by digging out the plant's crowns, eating three to four inches below the ground. Needless to say, the only thing the farmer received for his contribution to the rabbits' Epicurean delight was a dead field. Rabbits, rodents, and carrion were the mainstays of the coyotes' diet; however, as domestic animals became more abundant and easier to obtain, many coyotes became lazy, preferring the easy catch of a tender calf or lamb. Ranchers and farmers sought various solutions to their predator problems. Rancher Reuben Long stated, "Ever since the first cowboy rode into coyote country with his coiled riata on his saddle, cowboys have been trying to rope the elusive wild dog of the desert." ${ }^{\text {78 }}$ Coyote hunting was an exciting method of augmenting one's income. The market for coyote pelts was good until "1934 or 1935" and many men, including Ontko's father, earned money trapping them. ${ }^{79}$

The jack rabbit problem in Harney County was so bad that homesteaders appealed to the county court. In 1915, in an attempt to solve the situation, the court posted a five cent bounty. This proved to be a windfall for homesteaders, for whom the bounty may have been their only source of income. In this one

\footnotetext{
${ }^{77}$ Bowman, 98.

${ }^{78}$ Jackman and Long, 189.
} 
year, people brought in 1,029,182 rabbits for which the court paid out $\$ 51,459.10$ ! Unprepared for this monetary outlay, the court discontinued the bounty because most of the homesteaders paid no taxes and the ranchers objected to subsidizing farmers. Rabbit round-ups and poisonings were the primary methods homesteaders used to get rid of the "pests." The round-ups became social events where whole communities gathered together. People formed a crescent and drove thousands of rabbits into a three sides closemesh wire pen where the men and boys would club the animals to death as the women served hot coffee and sandwiches. It was not uncommon to kill as many as 5,000 rabbits. $^{80}$ None of the above mentioned methods provided lasting predator control. Successfully adapted to desert conditions, these animals continued to flourish.

While the land may have been inhospitable, most of the people were not. There was a strong sense of community. Residents worked hard on their own land and usually were quick to help a neighbor in need whether that was help with the harvest, hauling lumber from a distant saw mill, branding cattle, or caring for a mother and her newborn baby. "Neighbors would have benefit parties if a family had a calamity, like a fire." ${ }^{\text {81 }}$ According to Jerry Brummer, if one was a significant distance home, it was common to stop at another homesteader's house, fix something to eat, and if necessary spend the night, even if the owner was not there. "The rule was that you had enough wood so

\footnotetext{
${ }^{79}$ Ontko interview.

80 Jackman and Long, 196.
} 
the next person could build a fire." ${ }^{82}$ No one ever locked their door against a neighbor in need. The visitor customarily replaced whatever food or fuel he or she used.

For those separated by miles from their nearest neighbor, social gatherings provided a welcome break in the work routine and strengthened the bonds of community. Flora Beoletto Gillmor stated, "There were always doings at school," and at box socials there were "easily one hundred people." 83 Henry's Mill, a saw mill on Newsom Creek, had a round house where locals "would have dances and everybody played an instrument." ${ }^{14}$ The Prineville Grange was the site of many dinners, dances and other "doings" in which whole families participated. Horse racing was another well-attended event. The Fourth of July and Thanksgiving were festive occasions which drew large crowds. No Fourth of July celebration was complete without a baseball game. Players from Post and Prineville combined to form a community team which played neighboring teams. These tournaments were "a big deal," as locals gathered to cheer on their home team and socialize. ${ }^{85}$ Thanksgivings were community potluck events. Locals usually congregated at the Prineville

\footnotetext{
${ }^{81}$ Gillmor interview, 20 July 1996.

${ }^{82}$ Brummer interview, 20 July 1996.

${ }^{83}$ Gillmor interview, 20 July 1996.

${ }^{84}$ Gillmor, 20 July 1996.

${ }^{85}$ Interview by author, Frances Bushnell, 20 July 1996 at the home of Mr. And Mrs. Jerry Brummer, Prineville, Oregon.
} 
Grange but on occasion Henry and Rebecca Gray hosted Thanksgiving dinner at their large ranch, the Bonnieview. ${ }^{86}$

The homesteaders built a strong community with enduring friendships. Some left shortly after they arrived; some stayed a long time; but, unfortunately, "eventually nearly all failed and left." ${ }^{187}$ All were affected by the environment. To each the desert gave something. It influenced one's outlook and character. In order to survive, men and women had to be able to appreciate their surroundings. "If a man is big enough to expand with his surroundings, he becomes broader, more tolerant." ${ }^{188}$

The homestead era was pathetic, I suppose, looking back on it, but at the time it didn't seem so. It was exciting and there wasn't anyone to tell those folks, licked after they started, that they were ill-fed, ill-housed, and ill-advised. They were all on the desert with a common cause. ${ }^{89}$

Like others, Alice Day Pratt arrived full of hope and eager to begin her life as a homesteader. Despite her hardships, Pratt persevered. She brought new ideas to the community. She rejoiced in the beauty of the land, her animals, and the friendships she developed, which endured until her death in 1963.

${ }^{86}$ The Crook County Historical Society Museum has a photograph which Mary DeMaris Wilson identified as a Thanksgiving gathering at Bonnieview. Among those she identified in the photo was Alice Day Pratt.

${ }^{87}$ Jackman and Long, 10.

88 Jackman and Long, 10.

89 Jackman and Long, 52. 
Chapter 2

\section{WOMEN HOMESTEADERS: WHY DO IT ALONE?}

(The article I wrote) was about old maids. "Happy Women" was the title, and I put in my list all the busy, useful, independent spinsters I know, for liberty is a better husband than love to many of us. ${ }^{90}$

At last (my brother Fuller) told someone that he thought it a wonder that I, a girl alone among strangers, had done so well - better than most of the men had done. ${ }^{91}$

From the Colonial Era to the Civil War, American attitudes toward women ranged from thinking of them as sinful, people to be disdained, or thought of as defective. Seventeenth-century New England Puritans believed single women were "a menace to the social order" and "described old maids as fit only to lead apes in Hell." Although women truly were helpmates who lightened the work load of their husbands -- whether they were farmers or merchants -- their true destiny was believed to be marriage and motherhood. By the eighteenth century, society's condemnation of single women was not as severe but it considered the solitary state disgraceful. During the nineteenth century, single women were thought to be not only socially deviant, but also biologically deviant. Because pregnancy and childbirth are "normal" functions, advice literature cautioned women that their failure "to fulfill their destiny" as wives and mothers would bring about disease in their old age. By

${ }^{90}$ Lee Virginia Chambers-Schiller, Liberty, A Better Husband (New Haven: Yale University Press, 1984). This is an excerpt from the diary of Louisa May Alcott, 14 February 1868. 
the end of the nineteenth century, changing attitudes toward marriage viewed it in theory as more companionate and emotional, which led to another change in how society perceived singleness. At this time it was considered to be a social disease and instead of referring to them as "spinsters," the public began calling single women "old maids." These "old maids" challenged the social order. ${ }^{92}$ They stepped out of the domestic sphere and began to seek opportunities for employment, independence, and property ownership, all of which previously had been the prerogative of men. That single women could live fulfilled, independent lives had been incomprehensible only a few decades earlier.

Between 1815 and 1840, industrialization accelerated these attitudinal changes as newly industrialized urban centers, particularly those in the North and East, attracted young single women to work in factories. While marriage and domesticity were idealized, particularly during the antebellum period, more women, particularly white and middle class, began to think seriously about which fate was worse: being single or being unhappily married. Women began demanding more independence, notably financial independence, and choice in lifestyle. Employment and education were keys to independence; the educated woman had the ability to earn her own money, the means to empowerment. Writing in 1868 to the editors of The Revolution, Matilda E.J. Gage argued for the empowerment of women and their ability to control their

91 Philip L. Gerber, ed., Bachelor Bess: The Homesteading Letters of Elizabeth Corey, 1909 - 1919, with a Foreward by Paul Corey (lowa City: University of lowa Press, 1990). 
own destiny. She pointedly argued against the "crime" of "enforced motherhood," attacking the institution of marriage as one of oppression. Even though married women were responsible for managing the home and children, the real authority belonged to the husband. Money and property, which assured power, bypassed married women.

Money is but another name for power, it is but another name for bread, it is but another name for freedom, and those who possess it not are the slaves of those who do... History is full of the wrongs done the wife by legal robbery on the part of the husband. I need not quote instances; they are well known to the most casual newspaper reader. It is accepted as a self-evident truth, that those 'who are not masters of any property, may easily be formed into any mould. 93

Middle class women campaigned most vigorously for female empowerment and liberty. Their husbands' income was substantial enough that they could hire household help. These women were educated, and most had already raised their children so they had leisure time to read and to form interest groups. They were the organizers of abolitionist activities. They campaigned for temperance and suffrage. On the frontier, they created communities to imitate the stable and orderly societies they left behind, organizing schools and churches. Many women, including African-Americans, became involved in state or national political campaigns, notably suffrage and temperance. It is important to note that the first twelve states to pass women's suffrage were in the West where men and women, accustomed to traditional gender roles,

${ }^{92}$ Chambers-Schiller, 11, 167, 171, 193. 
were redefining these roles. ${ }^{94}$ Although these nineteenth century women made strides for female empowerment, they still functioned within the domestic sphere. Impoverished, working class, and farm women did not always have the advantages of the middle class, but they too, knew that education, property, and money were means to greater independence and autonomy.

Homesteading was a means to that end. The vast lands of the public domain were dwindling: settlers claimed acreage; speculators bought up large parcels hoping to make substantial profits; and the federal government subsidized railroad coffers by giving them thousands of acres.

While historians debate the extent to which the Homestead Act democratized American society, it was a means of empowerment for more than 350,000 Americans, particularly women..$^{95}$ The terms of this law were not

${ }^{93}$ Matilda E.J. Gage, "Is Woman Her Own?" in Public Women, Public Words: A Documentary History of American Feminism, Vol. 1, Dawn Keetley and John Pettegrew, eds. (Madison, WI: Madison House, 1997), 252.

${ }^{94}$ See Lois W. Banner, "Elizabeth Cady Stanton: Early Marriage and Feminist Rebellion;" Sojourner Truth, "And a'n't I a woman?;" Mary C. Vaughn, "'We would act as well as endure," in Women's America: Refocusing the Past, $3^{\text {rd }}$ edition, Linda K. Kerber and Jane Sherron De Hart, eds. (NY: Oxford University Press, 1991), 216-232; Nancy Woloch, "Frances Wright in Nashoba" and "Benevolence, Reform, and Slavery, 1800-1860," in Women and the American Experience, Volume One: To 1920 (NY: McGraw-Hill, Inc., 1994), 154203; Ruth Barnes Moyniham, Rebel for Rights: Abigail Scott Duniway (New Haven: Yale University Press, 1983); Paula Baker, "The Domestication of Politics: Women and the American Political System, 1780-1920," in Unequal Sisters: A Multicultural Reader in U.S. Women's History, $3^{\text {r }}$ edition, Vicki L. Ruiz and Ellen Carol DuBois, eds. (NY: Routledge, 1994), 85-110; Linda Gordon, "Black and White Visions of Welfare: Women's Welfare Activism, 1890-1945, in ibid, 157-185; Linda F. Dickson, "Lifting as We Climb: African American Women's Clubs of Denver, 1880-1925," in Writing the Range: Race, Class, and Culture in the Women's West, Elizabeth Jameson and Susan Armitage, eds. (Norman: University of Oklahoma Press, 1997), 392.

${ }_{95}$ The total amount of land distributed for free to the 31 million US citizens actually was very small, the agricultural usefulness marginal, and the Act lacked safeguards to protect settlers and prevent abuse, particularly from speculators. The government withheld millions of 
gender specific; it stated "any person who is the head of a family," was at least twenty one years old, and an American citizen or one who had filed their intention of becoming naturalized was eligible. Single women headed their own families and thus had the legal right to own property.

It is not surprising that widows constituted a large percentage of homesteaders. Many had been the children and/or wives of farmers. They were accustomed to the workings of a farm, oftentimes managing the farm while their husbands were absent conducting business or fighting in wars. Remarking about her mother's ability to cope with life in the "wilderness of northern Michigan," minister and prominent suffragist Anna Shaw Howard said of her father: he "sent my mother and five young children to live there alone until he could join us eighteen months later, he gave no thought to the manner in which we were to make the struggle and survive the hardships before us." 96

A vast number of women crossing the continent during the 1840 s and 1850 s suffered the heartbreaking loss of their husbands. ${ }^{97}$ Being hundreds of

acres from the public. Paul Gates reported that Congress granted 125 million acres to railroads, 140 million acres to new states for their management and sale, and in 1862, 175 million acres were included in Indian reservations. Secret negotiations with certain Indian tribes resulted in five treaties authorizing the sale of 9,500,000 acres in Kansas to railroads. Gates, History of Public Land Law, 395-397. White Euro-Americans disproportionately benefited, however, a few claims were filed by individuals with Spanish surnames. Following the Civil War, some African-Americans homesteaded in the north. Subsequent to the Dawes Severalty Act of 1887, the government granted homestead rights to Native Americans. Patterson-Black, Western Women in History and Literature, 17. See also Henry Nash Smith, Virgin Land, 189-194.

${ }_{96}$ June Sochen, "Frontier Women: A Model for all Women?" South Dakota History 7 (1976): 38.

${ }^{9}$ Of 96 women's diaries examined by Lillian Schlissel, 18 women reported the death of either their husband or another woman's husband. If these numbers are representative of the 
miles and months away from former homes, these women had few options. Many quickly remarried, some did not.

Anne B. Webb studied 259 out of an estimated 2400 women in Minnesota who homesteaded between 1863 and 1889 without the aid of a husband for at least one year. She described Emeline Guernsey as typical of this group. Like many, the Guernseys had been farmers. At the time of her husband's death, Emeline had material assets, technical knowledge, and experience running a farm. Additionally, she had four children capable of helping her. ${ }^{98}$ For six years Guernsey continued to operate the Pennsylvania farm her husband had owned, but in December 1858 she sold that farm for $\$ 4000$. She moved her family to Stacyville, Mitchell County, lowa, five miles south of the Minnesota border, where she immediately bought 480 acres. Guernsey speculated in land, buying another 480 acres and nine town lots. By 1861 she was selling parcels of land and earning substantial profits. Guernsey was fortunate; she had capital, which she invested wisely. "She clearly was not afraid to put her capital into land, one of the commonest and probably also one of the safest investments before extensive industrialization."99

Not all widows, however, were as financially prosperous as Guernsey. Harriet Griswold's husband died in September 1857, less than a year after the family of six moved onto their claim outside of Cambridge, Minnesota. Their

hundreds of families who crossed the continent between 1841 and 1867 , almost $19 \%$ of the women were widowed. Lillian Schlissel, Women's Diaries of the Westward Journey (NY: Schocken Books, 1982), 233-245

${ }^{98}$ Guernsey actually had five children. The youngest, however, was born shortly after its father's death, and would be of no help for a few years. 
first crop consisted predominately of potatoes and beans, the rest devoured by gophers and birds. Griswold's family in the East sent her money when they could afford to do so but it was not enough to sustain the family so she took in boarders, usually lumbermen, but neighbors undercut her prices. Since she had no team, she hired men to plow her land, paying them one dollar and fifty cents to two dollars an acre. Even after she purchased a team, she still hired help to do the heavy plowing. Although Harriet continued to farm at least through the 1860 s, she never did own her land. Money was a constant worry. She sold her crops but her records show she bought large items partially on credit. It is not known if Harriet ever remarried, but one letter indicated she feared she might be worse off if she did. ${ }^{100}$

After her husband died in a railroad accident, Eleanor Pruitt Stewart worked as a laundress, housekeeper, and furnace tender to support herself and her young daughter before answering Clyde Stewart's ad for a housekeeper and hired hand in Green River, Wyoming. She filed a claim to land adjoining Stewart's property which had "a grove of twelve swamp pines" where "I am going to build my house. I thought it very romantic to live on the peaks amid the whispering pines, but I reckon it would be powerfully uncomfortable also." ${ }^{101}$ Using the income generated from working for Stewart, Elinore built her own house and farmed her land. Writing in 1913 to her friend

${ }_{99}^{9}$ Anne B. Webb, "Forgotten Persephones," Minnesota History 50 (Winter, 1986): 143.

100 Webb, "Forgotten Persephones," 139-141.

101 Elinore Pruitt Stewart, Letters of a Woman Homesteader, with a Foreward by Gretel Ehrlich (Boston: Hougton Miffliln Company, 1988, orig. 1913, 1914, The Atlantic Monthly Company, renewed 1942, Elinore Pruitt Stewart), 7. 
Mrs. Coney, she reflected upon her lifestyle choice stating that she had wanted to write about it for a long time, "but could not because until now I had not actually proven all I wanted to prove. Perhaps it will not interest you, but if you see a woman who wants to homestead and is a little afraid she will starve, you can tell her what I am telling you." She described the potato crop, vegetable garden, and livestock from which she and daughter Jerrine reaped the benefits of their hard work.

So I selected my potato-patch, and the man ploughed it, although I could have done it if Clyde would have let me... I have almost an acre in vegetables. I irrigated and I cultivated it myself... I milked ten cows twice a day all summer; have sold enough butter to pay for a year's supply of flour and gasoline...I have raised enough chickens to completely renew my flock, and all we wanted to eat, and have some fryers to go into the winter with... I raised a great many flowers and I worked several days in the field. In all told about I have had no help but Jerrine.

Guernsey, Griswold, and Stewart initially took similar paths which had very different endings. Although Stewart did remarry, she did not forsake her land, continuing to farm it herself. These three women exemplify the spirit of hundreds of widows who had the confidence to continue on alone, seeking new opportunities as property owners.

Homesteading provided an escape for women in unhappy or abusive family situations. Divorce was difficult to obtain and, if granted, almost

${ }^{102}$ Stewart, 279-281. Stewart's life as described in her popular book in fact differs from her actual life. Although she wrote about a strong, independent woman who was capable of proving up her own homestead, she married Clyde soon after moving to Wyoming and had help making her proof. These facts, however should not diminish her staunch belief that single women were capable of being independent homesteaders. She is a reflection of the individualism of the era. See Sherry L. Stewart, "Single Women Homesteaders: The 
invariably favored the man. Besides being scorned by society, divorcées found themselves completely without resources, and often without their children.

Following the death of her husband, Bess Corey's mother "made it clear that there was not room at home for all the children." She favored her sons and since Bess was the oldest, assumed that she had the best chance for survival. Feeling that "she had been pushed precipitously and with a rather rude shove from the familial nest," she left lowa and, "probably with no more than the dimmest recognition of what she was doing "she became one of thousands attempting to forge a new life on 160 acres. ${ }^{103}$ Stanley County, South Dakota, land of "male prerogative," became Bachelor Bess's proving ground where she, a single woman, taught school and "ranched' from 1909 until 1935 when she was forced from her homestead, a victim of the Depression and the Dust Bowl.

Even though attitudes concerning the "proper" role of women were changing, many single women still saw themselves belonging to the domestic sphere of wife and mother. Some considered homesteading a means to marriage. Property ownership equaled wealth and as such, women could use it as a dowry. Although there was no shortage of men on the Western frontier, a woman who owned her own land was in a better position to attract a

Perplexing Case of Elinore Pruitt Stewart," The Western Historical Quarterly 22 (May 1991): 163-183.

${ }^{103}$ Gerber, Ivii-Iviii. 
wealthier man. If the marriage should prove to be unsatisfactory, she would have her own land from which to earn a living.

Not all women sought homesteads to alleviate unfortunate circumstances. Laura Crews, whose mother successfully claimed land in lowa in 1891, rode seventeen miles in fifty nine minutes in the race for land in the Cherokee Strip. For many years she worked on her claim, living in a dugout, digging her own well by hand, surviving on cornbread and rabbit stew. Until oil was found on her property, her only source of income had been selling eggs for two cents per dozen. Crews remained in Garfield County, Oklahoma her entire adult life until her death at age $105 .^{104}$

Sisters Ida Mary and Edith Eudora Ammons "had never questioned the impulse which led two young city girls to go alone into unsettled land, homesteading." Their "people had been pioneers." Self-reliant from a young age, Eudora and Ida Mary foresaw financial difficulties at home and, in their early twenties, they decided to make it on their own. Influenced by girlfriends who "talked about 'going homesteading' as a wild adventure," they "first thought the idea was absurd," but, after giving it another thought, decided to give homesteading a try. The two city girls "were wholly unfitted for the frontier." Eudora wrote," we had neither training nor physical stamina for roughing it. When I tried to explain to an uncle of mine that I wanted to go west, to make something of myself, he retorted that 'it was a hell of a place to do it." They chose to homestead near the Lower Brulé Indian Reservation, in 
central South Dakota where they risked "the hazards of a raw country alone, cutting ourselves off from the world of everyone and everything we had ever known." 105 In 1907 the Ammons sisters filed a claim on a quarter section which had reverted back to the government because the owner left before he completed proving up. Since a shack already existed, they did not have the expense of building one. Like Bess Corey, Alice Day Pratt, and countless other women, Eudora and Ida May found it necessary to have an income. Ida Mary initially chose the most common of female professions, school teaching, and Edith ran a newspaper, The Wand. Not satisfied to stay on their homestead after proving up, the sisters bought a relinquishment on the Lower Brulé reservation where Ida Mary became the only woman to run a post office on an Indian reservation. They endured the unmerciful prairie conditions: blizzards, winds, drought, and raging fire which, in less than thirty minutes, destroyed their home, the post office, store, and the print shop. They had nothing left but their land. Like the Phoenix, they rose from the ashes to begin again. Ida Mary later married and remained on the land. Edith reassessed her situation and deciding that her work on the Brulé was accomplished, she ventured off "empty-handed with no fixed program or goal" to Wyoming where she would help new land seekers work together to colonize a raw new land. ${ }^{106}$

${ }^{104}$ Patterson-Black, Western Women, 24.

${ }^{105}$ Edith Eudora Kohl, Land of the Burnt Thigh, with an Introduction by Glenda Riley (St. Paul: Minnesota Historical Society Press, 1986, orig, Funk and Wagnalls, Inc., 1938), 5-6.

${ }^{106}$ Kohl, Burnt Thigh, 292. 
Single women carried the full responsibility of fulfilling the homestead requirements, planting and harvesting, and earning an income. Marriage could help distribute the work load and provide a solution to loneliness, yet many zealously guarded their independence, their freedom from social constraint that homesteading provided. "It seems clear that the life of a single woman, or at least a childless one, was a cut above that of her married sister on the Great Plains frontier. Partly that is because the single or childless woman could devote her energy to her own survival and growth; the woman with numerous children or an oppressive husband was most often engaged in a moment-to-moment battle for survival." 107

Despite the all-consuming, neverending work, homesteading by oneself was not a prescription for a life of loneliness. Edith Kohl wrote, "We were young and demanded some fun, and feminine enough to find life more interesting when the young men who were homesteading began to gather at the shack."108 She described hauling Ida Mary's piano "all over the Strip" and going to winter parties and dances. "Bachelor Bess" Corey and Alice Day Pratt both document adoring suitors. In a letter to her brother, Fuller, Bess wrote,

Gee I wish you were out here to drive away the men - darn 'em. The wemon [sic] say 'You'll have to let 'em love you up a little or you'll never get along in Dakota' but I can't bring myself to it. There is one old fool here who is gone on me and was telling Mrs. Reese

\footnotetext{
${ }^{107}$ Patterson-Black, Western Women, 22.

${ }^{108}$ Kohl, 71.
} 
about it She told me and I dont [sic] know how l'll ever shake him off. ${ }^{109}$

Two months later in a letter to her mother, Bess wrote: "Its a desperate game we are playing - we three - Ella is evidently playing for keeps, guess I'm playing for excitement, and getting it."110

Women farmers were gaining acceptance, yet they still had to battle the prejudices of those who believed this role to be unsuitable for a woman. They forced the public to re-evaluate and redefine their beliefs of acceptable gender roles and social hierarchy. Defending the male prerogative, some people questioned the suitability of women to own farms, citing their "aloofness" from neighborhood co-operation to secure better roads, schools, and more scientific methods of farming. In addition, some accused women of being a "menace" because they were not "in harmony with the advancing economic thought about conserving the fertility of the soil" to sustain continued productivity. Refuting these arguments, Virginia Meredith wrote in the Breeders Gazette:

Farming is the ideal occupation for women who have a taste for country life. The markets of the world are hers, with no discount anywhere because the grain or meat was raised by a woman. The sources of information about methods in farming are everywhere open to her; the agricultural college, the experiment station and the department of agriculture draw no lines against her, as do the schools of medicine, law and theology. The superior opportunity to make a home for herself amid conditions that promote health, gratify the love of outdoors and give a chance for neighborly helpfulness constitutes the final and outstanding reason why agriculture offers the ideal business

\footnotetext{
${ }^{109}$ Gerber, 25.
}

${ }^{110}$ Gerber, 40. 
whereby a woman may achieve financial independence in harmony with social righteousness. ${ }^{111}$

The women who homesteaded sought an alternative to what they believed to be unsuitable conditions. As a group, they did not have a political agenda. They did not set out to change societal attitudes regarding gender roles. They were capable individuals who simply wanted what so often throughout AngloAmerican history has been denied to women: independence and empowerment. For women like Alice Day Pratt, liberty was a "better husband."

${ }^{111}$ Virginia C. Meredith, "Women Farmers," Breeder's Gazette 67 (1915): 854. 
Chapter 3

\section{THE EARLY YEARS}

The beauty of the prairies and the destruction of prairie life! These go together in my memory as they go together in our history. ${ }^{112}$

It seems predictable that Alice Day Pratt sojourned west to homestead in the rugged High Desert. She was one in a line of forebears with an independent "pioneering spirit." In 1636 her English ancestors, John Clark, his daughter Elizabeth, and Lieutenant William Pratt, members of the Massachusetts Bay Colony and "searchers after perfect freedom (and other things)," joined one of clergyman Thomas Hooker's walking parties. Still looking "toward the sunset with unfulfilled desire," this group of hearty individuals "followed Indian trails through the budding woods and flowery meadows... where few white men had walked before them; where, from fastness in rock and tree, many eyes gazed upon them, where lovely choirs, which had known no civilized audience, sang to them at dawn." ${ }^{113}$ This small walking group founded the colony of Connecticut.

The Pratt pioneering spirit continued. Alice's great grandfather, Deacon Phineas Pratt (1747-1813), a clockmaker, and member of the Revolutionary army, was commissioned to make machinery for The Turtle, the first submarine to operate in American waters. Julius Pratt, her grandfather, was a trailblazer in the manufacturing of ivory articles. He was a State Senator

\footnotetext{
${ }_{112}$ Alice Day Pratt, Three Frontiers, (New York: Vantage Press, 1955), 3.

${ }^{113}$ Pratt, Three Frontiers, v.
} 
from Connecticut and an uncompromising abolitionist who was quite upset that a shipment of his fine ivory combs had been transported in the same ship with African slaves. When a friend told him that his stance on slavery would significantly reduce the sale in the South of his fine-toothed ivory combs which were a popular delousing agent, Pratt replied, "Let 'em go lousy!"114

Reaping the benefits of Julius's profitable ivory business, William McLain Pratt, Alice' father, was well educated, graduating from Williston Academy and Rensselaer Polytechnic Institute with a degree in engineering. Instead of seeking employment in engineering, he went to South America, where he crossed the Andes by mule pack train, to investigate prospects for an ivory market business.

When the Civil War began, William's "unfeigned love for the democratic experiment" and his fervent belief that the Union "cannot fail," brought him home. Despite inducements of a tour of Europe and Africa and a threatened disinheritance should he join the army, William stubbornly enlisted in the Eighth Connecticut Regiment. Following his recovery from a bullet wound at Antietam, he returned to his regiment and carried dispatches to General Grant. Fortunately, Julius was so proud of his son that he rescinded his threat and after William's discharge, sent him on an extensive tour of Europe, partly pleasure, partly ivory business, and partly to search out ancestral landmarks.

William married Sophie Rand, a graduate of Sarah Porter's school, on 7 October 1869. With no monetary worries, the two lived on the Pratt land in 
Meriden, Connecticut until the fall of 1870 . Failing health, resulting from his war wound, and advice from his physician to move west to a drier climate, triggered "the adventurousness of his [William's] pioneer spirits." ${ }^{115}$ Sophie, however, was not of a like nature, but being "one of those for whom decisions are made," regretfully left her family. William took his wife and first-born daughter, Sophie Caroline, to Mankato on the Minnesota River where the fertile soil produced abundant crops and dense native vegetation provided a playgound for children. Among a settlement of inexperienced American farmers and Germans, Scandinavians, and Irish "straight from Europe," Alice was born 16 June $1872 .{ }^{116}$

While living on the Minnesota prairie, Alice spent much of her time observing and learning about nature. From her parents she developed an interest in and love of all nature. Even as a child she could not accept the killing of an animal. The family enjoyed picnics at a nearby lake, yet, for Alice, the pastoral settling was destroyed by William's fishing and hunting. Upon seeing her father "bring in flocks of quail and loads of ducks," she "stroked their beautiful, soft feathers and admired their iridescent colors, but their poor dead eyes, the blood dripping from their beaks!" horrified her and she asked herself, "why was my father so happy to have done this?"117 Her profound love of animals and aversion to killing them, even for food, was constant

\footnotetext{
${ }^{114}$ Pratt, Three Frontiers, vii.

${ }^{115}$ Pratt, Three Frontiers, $x$.

${ }^{116}$ Pratt, Three Frontiers, v-xi.

${ }^{117}$ Pratt, Three Frontiers, 3.
} 
throughout her life. Writing about the delights and hardships of raising a herd of Jersey cows on her homestead, she stated, "Since I have known the delights of being a foster mother to these fawn-like little Jerseys, veal has become an abomination to me, and I fully believe that chemistry and developing sensibility, hand in hand, will deliver us from the stockyards and the habit of feeding upon our fellow creatures." 118 It is not known at what age Alice chose to become vegetarian, but prior to age 23 she "was determinedly vegetarian." ${ }^{119}$ Her decision to eschew eating animal flesh was "definitely because of her love of animals." According to her nephew Walden, no one else in the family was vegetarian, but everyone respected her views. Walden stated that he, his brother, and his father have done a little fishing but none have hunted. While this may be natural inclination, he doesn't dismiss the fact that Alice's love of animals might have influenced her brother. ${ }^{120}$ In Three Frontiers, she made a "plea to hunters not to disguise their sport as a humanitarian activity." ${ }^{121}$ As a homesteader in the cattle country of Central Oregon, Alice's attitudes towards animals unquestionably set her apart from her neighbors. In "Jerseys" she described going out on bitterly cold nights to check on her calves, particularly Laddie, to insure they would be warm. "Passing stockmen regarded this dainty and blanketed calf with derision. Their little Whitefaces were breasting the rigors of the winter storms in

${ }^{118}$ Alice Day Pratt, "Jerseys" in Atlantic Monthly 147 (January 1931): 55-56.

${ }^{119}$ Pratt, Teacher's Trek, copy of unpublished manuscript, original is in possession of Walden Pratt, Arvada, Colorado, 4.

${ }^{120}$ Walden P. Pratt, Arvada, Colorado correspondence to author, 31 October 1996.

${ }^{121}$ Pratt, Three Frontiers, 39 (fn). 
complete exposure, to live or die as their constitutions or the untempered wind might determine. 'You just oughter go by' said one to another, 'and see how she's got her calves dolled up."' Looking out at her seven ponies grazing in a field of bunch grass she wrote in "Hippos," "my ponies excite the amused comment of practical men, since they consume what might just as well be converted into juicy beefsteak or fat-dripping mutton chops." 122

Alice's glorification of nature was not limited to animal life; she collected and identified flora in the area and studied the geology. Her interest in and study of nature, which began as a young child persisted until her death. At age seventy-one she was studying the three volume set of "Wells and Huxley's Science of Life."123 Her awareness of and relationship to the natural environment manifested itself throughout her life and can be seen in her writings. This connectedness to her environment is a feature somewhat unusual for women of this era. Elizabeth Hampsten, who has studied the writings of Midwestern women at the turn of the century, noted that most write of the land quite neutrally. "The land is somewhere outside." ${ }^{124}$ Describing letters written by women homesteaders, Hampsten saw little emotional attachment to the land and few mentioned going on picnics, walks, or horseback riding. In contrast, Pratt's books, magazine articles, and letters abound with references to nature, particularly bird and animal life, and what

\footnotetext{
${ }^{122}$ Alice Day Pratt, "Hippos" in Atlantic Monthly 147 (June 1931): 738.

${ }^{123}$ Alice Day Pratt, New York, NY, correspondence to William Pratt, 23 March 1943.

${ }^{124}$ Elizabeth Hampsten, Read This Only to Yourself: The Private Writings of Midwestern Women 1880-1910 (Bloomington: Indiana Press, 1982), 32.
} 
she observed on her numerous walks. One example of her sense of place is from an article entitled, "I Take to the Woods," in which she wrote of hiking in the Appalachians, in the Black Hills of South Dakota, and on Neahkahnie Mountain on the Oregon Coast:

Down from these castellated peaks dashed the little streams, cutting through snowy limestone, dark red sandstone, and gray granite, some of the most beautiful and rugged canyons in America. The precipitous, almost vertical walls are like the layer cake of the giants of the infant world. In the wallsheltered mouths of these canyons, mystic 'tepee circles' sinking slowly into the all-recording earth testify of many a happy hunt of the aboriginal American. ${ }^{125}$

Teaching in a small impoverished coal mining camp in Spadra, Arkansas, just after the turn of the century, she described the natural environment:

Just back of the cottages, as stated, began the beautiful Arkansas woods - woods not tropical nor yet northern. Like the climate, they were a blend, surprising now with a mildness and a tender beauty, now with a thrill and crispness. The prairie was rolling crinkled into ridges. On the ridges, oaks and maples rippled into an intoxicating variety of color both in spring and fall, highlighted in the spring by dogwood and redbud. The woods were carpeted with moss figured as early as February with a riot of violets and Quaker Ladies. ${ }^{126}$

Childhood in Mankato was almost idyllic but three years of drought and grasshoppers changed everything. Farmers were ruined and lost their mortgages. Alice does not say what occupation her father was engaged in, only that he was one of "those whose business was dependent upon the

${ }^{125}$ Alice Day Pratt, "I Take to the Woods," The Atlantic Monthly 150 (Sept., 1932), 312.

${ }^{126}$ Alice Day Pratt, Teacher's Trek, p. 21. 
prosperity of farmers." ${ }^{127}$ William lost everything including his inheritance and money he had invested for others. In 1877, hoping to profit from the influx of gold seekers and recoup his losses, he decided to move to the rapidly developing Black Hills where he "became a lumberman near Deadwood, Dakota Territory. William would not allow his wife and daughter to join him in "so rough a country." This move was hard for the whole family, especially for Alice's mother, whose loneliness and uncertainty as to when she would be reunited with her husband was compounded by the deaths in 1882 of Sophie Caroline, age twelve, and a one year old daughter, within a few months of each other. Alice believed that her father "never really appreciated the effect of this move on our young mother. He was, to the end of his life, unswervingly devoted to her - but he was sustained in their separation by the excitement of the adventure, the buoyant hope of success and the firm belief he would bring prosperity to her again, while she had only the waiting and the loneliness." 128 Although Sophie and Alice did make a visit to William, in South Dakota from 9 August to 24 September 1883 , the family was separated for eleven years. ${ }^{129}$

While living here, William attempted to improve the Pratt financial status by investing in mining stocks including $\$ 450$ in 1000 shares in a mine that "apparently had a well defined silver vein of good size - with the proper direction and dip." Unfortunately, this mine "proved worthless." In all he

\footnotetext{
${ }^{127}$ William's journal indicates that he was in the lumber business at this time. Walden Pratt, Arvada, Colorado, correspondence to author, 28 April 1998.

${ }^{128}$ Pratt, Three Frontiers, 13-14.

${ }^{129}$ William Pratt papers, original in possession of Walden Pratt, Arvada, Colorado.
} 
"threw away about $\$ 1000$ at this time." Several months later he reinvested in some other mines from which he "made a little money."130

In 1886 at age fourteen, ${ }^{131}$ Alice moved with her mother to Elk Creek, South Dakota, where "our rough little house of five rooms was surrounded by the park-like forest." In 1887 William was "employed by the F.E. \& U.V. Railroad (a part of the C \& S.W) to secure right of way between Rapid City and Sturgis." ${ }^{132}$ Following the completion of the railroad to Whitewood in 1887 , William bought lots, built a furniture store where he sold furniture and lumber which he bought from mills in Boulder Park and Elk Creek. ${ }^{133}$ Her father, "by invoking various claims of homestead and water rights, was to secure title to the canyon almost entire, including all of its majestic beauty. ${ }^{134}$ She wrote quite fondly of her life on the Elk Creek homestead. "We were always warm in the house and no fears beset us. Life was so simple that not much could happen to it." ${ }^{135}$ The family grew in size. Alice's maternal grandfather, Richard Rand moved in them. A brother Julius, "J.W.," was born 25 February 1888 and a sister, Marjorie, was born 19 June 1891.

${ }^{130}$ Pratt papers.

${ }^{131}$ Differing dates appear in Alice's writings. In Three Frontiers she says she and her mother moved to Elk Creek in the summer of 1886 after several years of "hindering circumstances" (p. 33) that prevented annual summer visits. In Teacher's Trek, Alice wrote that her father "planted his family in 1884" (introduction). William Pratt wrote, "In June 1886 Wife, Alice and Father Rand came to the Little Elk house to live and this was our home until we came to North Carolina in 1901." Pratt papers.

${ }^{132}$ William Pratt papers.

${ }^{133}$ William Pratt papers.

${ }^{134}$ Pratt, Three Frontiers, 35.

${ }^{135}$ Pratt, Three Frontiers, 37. 
All three children participated in the farming chores but, since Alice was by far the oldest, she had a greater responsibility. In addition, she helped her mother care for the two younger children and did some of the household sewing. ${ }^{136}$ Her grandfather did not like seeing women do the heavy chores but Alice delighted in the work, writing, "I took to it like a duck takes to water. From the first I had pre-empted the care of the horses." ${ }^{137}$ Here again, one sees Alice's preference for animals. She took turns with her father making trips to the post office and store, which, in the bitter cold of the South Dakota winters, were quite an ordeal. Her work ethic and experiences in Mankato and Elk Creek provided valuable preparation for making her own homestead.

Although the Pratt children did not regularly attend religious services, Christian principles permeated the household. According to her nephew, Alice's parents were Presbyterian and her mother relied heavily upon the Bible from which she surely must have taught Alice. ${ }^{138}$ She wrote, in Three Frontiers, that her mother was "social in her disposition" and "longed for her church association" that had been an integral part of her life prior to moving to the isolated Elk Creek and that her father did not attend religious services. Another influence could have been her grandfather, Rand, "an uncompromising Puritan" who "lived largely in his Bible." Alice stated that she received her early religious education from two periodicals, The Outlook and

\footnotetext{
${ }^{136}$ By this time, her grandfather Rand's rheumatism and asthma prevented him from contributing to the chores.

${ }_{137}^{13}$ Pratt, Three Frontiers, 37.

${ }^{138}$ William Pratt, State College, PA, correspondence to author, 30 July 1997.
} 
The Independent which "really were religious in those days." The Outlook "liberated her from inherited creeds" and introduced her to the theory of evolution which she embraced, based upon her studies of the geology, flora, and fauna of Elk Creek. ${ }^{139}$ Her writings, with the exception of Three Frontiers, do not divulge a religious affiliation, yet she appears to have been a devout (although unorthodox) and, according to her nephew, "exemplary" Christian. While her public writings do not disclose a religious affiliation, her letters to nephew William contain references to church attendance. Her responses to her nephews' attendance, prefer religion's social and moral benefits rather than orthodox dogma.

On 28 June 1936, she wrote from her home in Old Forge, New York, "I am glad you and Walden are in a good church and S.S. It will give you some interesting work and association. There ought to be plenty for all church people to do."140

Several letters written in the 1940 s praised John Haynes Holmes, a "famous preacher" who teaches the Bible "according to the modern and scholarly view." ${ }^{141}$ Holmes' social activism seems to have great appeal to Alice. The last chapter in Teacher's Trek, in which she described teaching on

${ }^{139}$ Pratt, Three Frontiers, 47-49. Although her father did not attend religious services in South Dakota, Alice's nephew William, wrote, "I know this is not true for his entire adult life." Pratt referred to his grandfather's diaries which contain references to various sermons and attending church with his family while living in North Carolina. William Pratt, correspondence to author, 4 May 1998.

${ }^{140}$ Alice Day Pratt, Old Forge, NY, correspondence to William Pratt, 28 June 1936, photocopy, original is in possession of William Pratt, State College, PA.

${ }^{141}$ Alice Day Pratt, New York, NY, correspondence to William Pratt, 22 January 1945, photocopy, original is in possession of William Pratt, State College, PA. 
Smith Island, Tylertown, Maryland (1943-44) is mostly devoted to her disapproval of the staunch theocracy of the community and the extent to which they adhered to their Biblical interpretations of the world even when there was scientific proof to the contrary. She is quite critical of hypocrisies exhibited by self-proclaimed Christians. She described the island children as quite wellbehaved "owing much to their religious training" yet she "noted with surprise that they were not especially truthful children;" they cheated on exams and twice lied to her, reporting school closures when in fact there were none. ${ }^{142}$ In a letter to William, she was quite appalled that the local pastor reported to the congregation that, while visiting a woman's home on the other side of the bay, he was horrified to find her preparing "A BRACE OF DUCKS WHICH THE HUSBAND HAD SHOT ON THE SABBATH DAY!" What Alice couldn't understand was the pastor's "logic" which condoned poaching, the "wholesale violation of civil law" prohibiting wildlife trapping, yet condemned doing it on Sunday, even though the man shot them between services. ${ }^{143}$

Consistent with her belief in Christian values rather than dogma, she lamented denominational divisions. On Christmas 1907, in Spadra, Arkansas, after being introduced to the local Catholic priest, she offered to gather the (coal) camp children together on Sunday afternoons for Bible stories and singing, assuring the priest that she was "no proselyter." The priest approved of her plan but to use a building for such services would require the permission

${ }^{142}$ Pratt, Teacher's Trek, 78. 
of Mr. Taylor, the president of the New York company that owned the camp. Alice eagerly sought Taylor's permission but was "quite unprepared for Mr. Taylor's blazing negative." Although many of the miners were Catholic, Mr. Taylor, a Christian Scientist, refused their request. Alice, who had no knowledge of "the war between Christian Scientists and Catholics" had difficulty understanding how "decrees of their religion" placed barriers between people who wanted only to work "for the good of their fellow man."144

Reading and writing were an integral part of Alice's life from early childhood until her death. In addition to fostering independence and a love of nature, both William and Sophie instilled in their children the value of education and an appreciation of literature. Speaking for her younger brother and sister, as well as herself, Alice testified to the benefits the Pratt children reaped from her mother's habit of reading to them and, when the children were older, the long winter evenings reading together at the table. Nephew Walden recalled many childhood visits to Niagara Falls where Alice lived with Marjorie and her mother during the mid 1930s. He has fond memories of Sophie reading A Christmas Carol every Christmas Eve and that "every evening they would take turns reading aloud from books that appealed to all of us." As Alice grew old, deteriorating eyesight made it impossible to do much reading and writing; however, her interest did not lag. In the few years

${ }^{143}$ Alice Day Pratt, Tylertown, Maryland, correspondence to William Pratt, 21 November 1943, photocopy, original is in possession of William Pratt, State College, PA.

${ }^{144}$ Pratt, Teacher's Trek, 22. 
preceding her death, a Mr. Beckett would come regularly to the flat to discuss current events and read to Marjorie and Alice. ${ }^{145}$

In accordance with the tradition of both the Pratt and Rand families, all three children pursued higher education. Alice attended the State Normal School in Spearfish, South Dakota. Julius, a noted American historian, specializing in diplomatic history, graduated from Davidson College, North Carolina in 1908 and in 1925 received his Ph.D. from the University of Chicago. ${ }^{146}$ Marjorie received a master's degree in education at Columbia. ${ }^{147}$

${ }^{145}$ Walden Pratt, Arvada, Colorado, correspondence to author, 31 October 1996.

146 Julius Pratt's writings include, A History of the United States Foreign Policy; America's Colonial Experiment: How the United States Gained, Governed, and in Part Gave Away a Colonial Empire; Expansionists of 1898: The Acquisition of Hawaii and the Spanish Islands; Challenge and Reflection: The United States and World Relationship 1900-1921.

${ }^{147}$ Pratt, Teacher's Trek, introduction, and William Pratt, correspondence to author, 31 October 1996. 


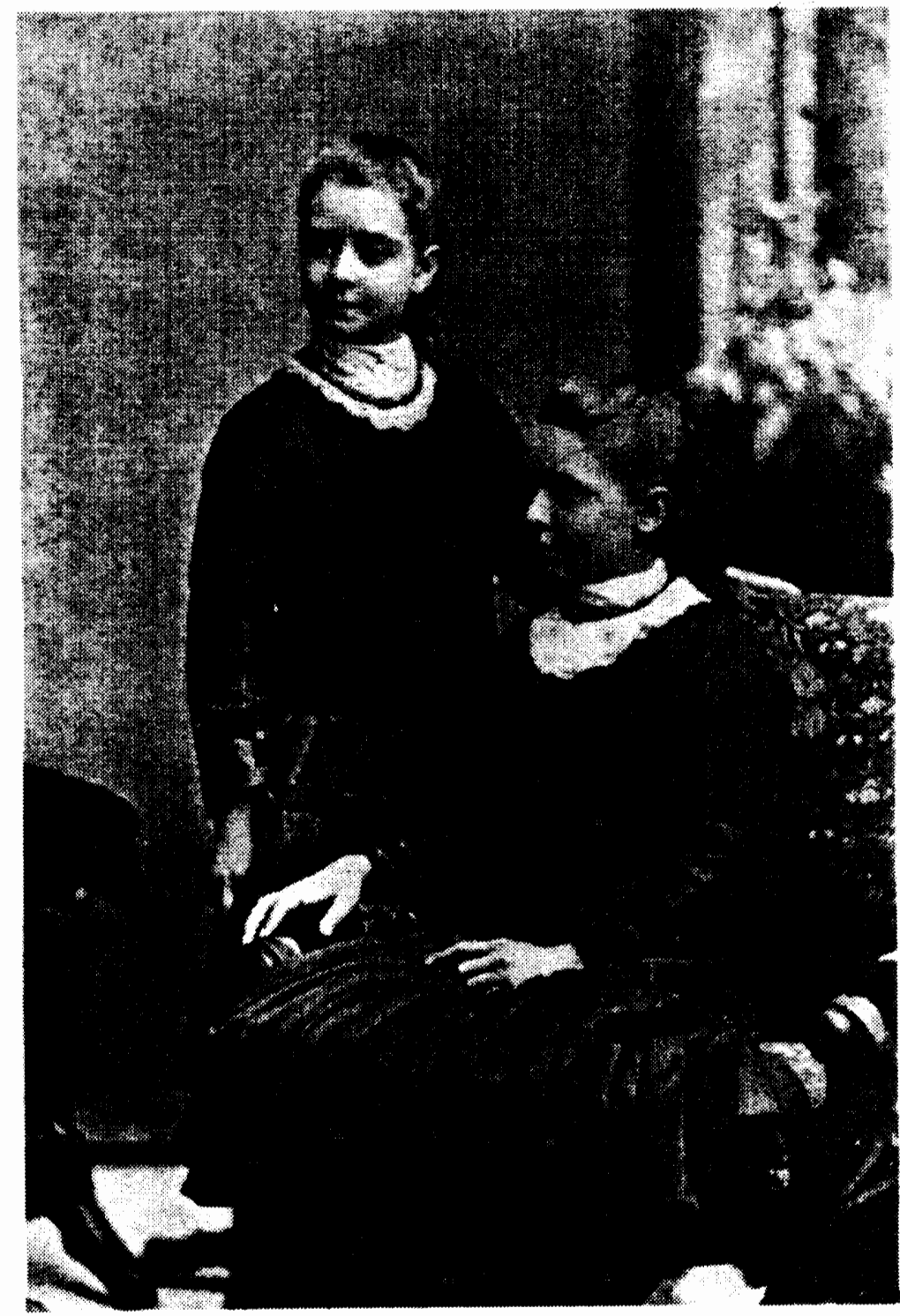

Alice Day Pratt and sister Sophie Caroline.

Mankato, Minnesota, approximately 1880-81.

Courtesy of Crook County Historical Society, Prineville, Oregon. 
Chapter 4

\section{TEACHER}

I will fly in the greatness of God as the marsh hen flies In the freedom that fills all the space

'twixt the earth and the skies. ${ }^{148}$

A teacher of independent nature, especially inclined to be progressive in nature, has no smooth waters to navigate in such a community. ${ }^{149}$

Teaching was one of the few professions widely available to women and acceptable within the general society. It appealed to women who desired independence and autonomy. Some women, in the profession, spent their entire adult lives teaching in a variety of locations throughout the United States and its territories. In the developing west, opportunities for teachers abounded as teachers brought a civilizing element to the rough frontier. Teachers were well-respected and desired members of the community. Numerous single women homesteaders were teachers. Although the pay was low, teaching provided money to hire help and buy supplies but on the negative side teaching took time away from farming. Unlike married homesteaders, there was no division of labor. One person had to do it all.

Alice certainly believed that teaching provided freedom, opportunity, and autonomy. During one meeting of a "Discussion Group," probably in 1939, "an enthusiastic young Communist" admonished the audience to rid themselves of the "shackles of custom, tradition, and religion." The speaker's question, "'Are

${ }^{148}$ Pratt, Teacher's Trek. 
you free?"' provoked Alice into serious and repeated reflection upon her life about which she "came to the conclusion that, during a long life, I had been gloriously free. Especially the question related itself to my professional life and it occurred to me that the American Public School Teacher might well serve as an example of a free citizen." She likened a teacher's certificate to an "open-sesame" to the doors of schoolhouses in every state, and "as a corollary of this privilege, she [the teacher] has the freedom of the soil from ocean to ocean and from border to border. She may climb the highest mountain, plumb the deepest canyons, sail the blue lakes, roam the flowery meadows, wonder at The Big Trees and shun the desert wastes." ${ }^{150}$ It is interesting to note that Alice referred to freedom in terms of the natural environment without reference to financial security, personal relationships, or societal acceptance. "One's course, to be most effective, must be in line with one's spontaneous loves and interests." ${ }^{151}$ For her, gratification came from doing "interesting things." Responding to a letter from William in which he must have told her about a summer job, she replied, "I (sic) be fully worth while, however small the pay. Doing interesting things is a lot better than just

${ }^{149}$ Pratt, Teacher's Trek, 54.

150 Pratt, Teacher's Trek, introduction. It is not known for certain when Alice wrote this manuscript. Her nephew Walden thinks she may have written it in approximately 1960. Although her manuscript stated she went to the Discussion Group "not long ago," in a letter dated 7 November 1939 to her nephew William, she told him of being on the "Social Action committee" and attending Sunday discussion groups in which a variety of viewpoints were welcome, including Fascism and Communism. If the session she is referring to did occur in 1939 , she would have been 67 years old and maybe she did consider that a long life. She did, however, live another 24 years. Considering the political climate in the United States during the 1950s and early 1960s, it seems more probable that discussions by those "studying alien ideologies" represented in New York City would have been more common in the mid to late 1930 s. 
earning money' (italics mine). ${ }^{152}$ Teaching allowed her the freedom to do interesting things: teaching in mountain schools of the Blue Ridge, North Carolina and coal camps of Arkansas, where she "took to the woods" hiking and camping in the Black Mountains; studying to be a kindergarten teacher in Chicago during the 1890s "awakening" of education; homesteading in Central Oregon; spending a four-day Thanksgiving break walking the coast section of the Lewis and Clark trail to Fort Clatsop; teaching in a Depression Era federally funded (and regulated) pre-school; and teaching in the "theocratic" community of Smith Island, Maryland. In all, teaching provided the freedom by which she traversed the soil between the Atlantic and the Pacific. ${ }^{153}$

Alice attended the State Normal School in Spearfish, South Dakota. She fully intended to attend college, but, for the lack of "cash-on-hand," and her father's inability to help finance her education, she did not realize her goal. Instead, she began her teaching career not far from the family home in a country school in Lawrence County, South Dakota. The district was so impoverished they could hire a teacher for only four months. Besides being very homesick, the inexperienced teacher found herself constantly challenged to prepare lessons for enthusiastic, yet "simple-minded" children who had no text books and by the outrageous behavior of a sixteen year old "big, bad boy."

${ }^{151}$ Pratt, Homesteader's Portfolio, 2.

152 Alice Day Pratt, Old Forge, NY, correspondence to William Pratt, 3 August 1941, photocopy, original is in possession of William Pratt, State College, PA.

153 This chapter will concern itself only with Alice's teaching experiences before and after her eighteen years as a homesteader in Oregon. Teaching in Oregon will be included in chapter five, "Homesteader." The purpose of this organizational structure is to place her as a 
An "unbalanced diet," "intensive school work," "the big bad boy," and uncomfortable accommodations took a heavy emotional and physical toll upon her. After the term's completion, she was more than happy to return to her family home. ${ }^{154}$

At age twenty-three, after spending her entire life amidst the beauty of sparsely populated Mankato and the Black Hills, Alice moved to Chicago, home to Progressive Era social enlightenment, Jane Addams, Hull House, the Settlement Movement, John Dewey, the University of Chicago, Francis Parker, Christian Scientism, the Columbian Exposition, art galleries, museums, the stockyards, and overwhelming impoverishment and human degradation ${ }^{155}$. Here she began student teaching in one of the kindergartens, a concept, along with day nurseries, promoted by the Settlement Movement aimed at

member of the Post/Prineville community and to demonstrate how interrelated the homesteading and teaching were.

${ }_{154}$ Pratt, Teacher's Trek, 2-6.

155 John Dewey who taught at the University of Chicago until 1904 and then Columbia University, transformed educational theory. He believed that a just and harmonious society could result from the intelligent application of scientific method to social problems. He believed that the place to begin was in the public schools, arguing that schools must not only teach democracy but embody the values in their cirriculum. He refused to allow desks and chairs to be bolted to the floor and encouraged children to interact not only with each other, but also with the teacher. Hull House and the Settlement Movement was begun by Jane Addams, the well educated daughter of a successful Illinois businessman, in 1889. Addams and two other women purchased and repaired the dilapidated home of Charles Hill. They and others lived in the house and daily served, poor, non-English speaking, and illiterate immigrants. They taught classes in nutrition, sanitation hygiene, dressmaking, civics, English, and encouraged the women to retain their ethnic crafts. Workers established nursery schools and day nurseries for working mothers, clinics, and recreational activities. Unlike other groups of the time, settlement workers did not blame the immigrant's poverty on moral failure. By 1895 there were fifty settlement houses in Chicago. See Jane Addams, Twenty Years at Hull-house (NY: The Macmillan Co., 1938). 
preventing the large number of deaths and accidents very young children experienced, the result of neglect as their impoverished parents worked. ${ }^{156}$

During her two years in Chicago, Alice encountered not only the philosophies of Dewey and Parker, but also Froebel, Voltaire and Rousseau, which surely must have been a departure from her intellectual experiences in Spearfish. She seemed, like others of the time, to wrestle with the dilemma of allowing children the freedom and spontaneity to explore their surroundings through play in accordance with their imagination versus the necessity of structure and regimentation. She described her efforts to integrate philosophical theories and concrete principles of "social and present existence" with the specific environment of the child as quite taxing. She was responsible for integrating music, art, and drama as well as understanding the culture of "up to eighty very young foreigners, from various types of homes and varying languages." Not only did she spend most of her day in class with the "tiny tots", but she additionally was required to get to know the children in their respective environments that would range from "a saloon, which was in the front room of the home" to a "bakery or grocery crowded with foreign goods." A typical day would begin at six o'clock with "a simple breakfast" and brief "morning housekeeping." Grabbing her lunchbox, she rode either the trolley or "elevated cable" to "the far places of the city" where, at the Settlement, she would be greeted by her "enthusiastic and miscellaneous crew and went heroically through the exercises of the morning." Teachers meetings 
followed a noontime lunch after which she traveled "to some other fardistant quarter for training in theory, art, music, and games," then back to her training school. She spent most evenings studying and preparing for the next day. Although this schedule consumed the majority of her time, the school required that she and her fellow classmates "should be imbibing such nectar and ambrosia as the city afforded," and to that effect, it subsidized their experiences. She wrote that she saw Ellen Terry as Rosamond and Guinevere, Henry Irving as Becket and King Arthur, the DeReskes in Siegfried, Cyrano de Bergerac, The Little Minister starring Maud Adams, and Theodore Thomas conducting his orchestra. For Alice, these four years in Chicago were quite exciting. "They were a decade to remember."157

While Alice believed in a personal freedom, that should begin in childhood, she also favored structure and discipline in the kindergarten. After leaving Chicago in 1898 for the Appalachians of North Carolina, she wrote, "I had never become a convinced devotee of laissez-faire education. Hence, it was something of a relief for me that Southern parents still believed in discipline and order and in "making the children learn." ${ }^{158}$ She rewarded disciplined and responsible behavior. Between 1907 and 1910, she taught in the coal mining camps of Spadra, Arkansas. Here the children lacked social and recreational resources so Alice devised a schedule of classes from nine to noon, three evenings a week of manual work, a library night, and one evening of social

\footnotetext{
${ }^{156}$ Pratt, Teacher's Trek, 7.

${ }^{157}$ Pratt, Teachers Trek, 9-11.
} 
activities including games, stories, and music. Only those who had contributed to the work activities could attend the socials. Her plan was wellreceived by the community and even the most apathetic students responded to the "universal instinct of the young human - 'to create,' otherwise 'to make things,' to construct, to paint, to model, to use material in a multitude of ways." She acknowledged that she was manipulating the students. However, she noted that the students were free to choose whether or not they would participate. In her three years in Arkansas, she reported no discipline problems despite the presence of "rough and undisciplined children." 159 This situation is quite a contrast from her first teaching assignment in which her inability to change the behavior of an extremely unruly boy caused her great anguish.

Although she remained at this location for three years, her manuscript, Teacher's Trek, stated that she went back to North Carolina in the summer of 1909 to teach in a summer institute for teachers. At this time, Alice revealed her willingness to teach African-American teachers. The superintendent asked if she would consider teaching "Negro" teachers, that "there was no obligation." Since segregated schools were the norm in the North as well as the South, it is quite possible she never had the opportunity to teach in anything other than a white school. Whether or not Alice had interactions with African-Americans prior to this is not known. Preconceived prejudices are 
expressed as stereotyped compliments. For example, she marveled at their wonderful singing voices and wondered "how much dramatic talent have (sic) been lost to the world through our indifference to this great source of primitive feeling and expression." Additionally, she had "no doubt" that they would be good teachers, "as they have always made good nurses, because of their sympathy and childlikeness." 160 In contrast, during World War II, she had the opportunity to teach English to refugee German Jews and was "surprised to find how genial and likeable (sic) they are," saying, "I never thought that I liked them very well." ${ }^{161}$ Here, again, one does not know what previous interactions might have influenced her, although the neighboring ranchers of Elk Creek, her childhood home, and the settlers whose children she taught in North Carolina were Scottish, Irish, Swiss, English, German, French, and Scandinavian. Perhaps it was an unfamiliarity with Judaism and Jews that provoked that statement. For the most part, Alice appears to accept or reject people on the basis of how they relate to other people and animals rather than their religious or political beliefs.

In 1930, when the Depression forced Alice from her homestead in Oregon, she went to upstate New York where her family was living. ${ }^{162}$ Here, in 1934 ,

${ }^{160}$ Pratt, Teacher's Trek, 14.

${ }^{161}$ Alice Day Pratt, New York, NY, correspondence to William, 23 October 1942, photocopy, original is in possession of William Pratt, State College, PA.

162 Her manuscript does not state to what city she moved, only that it was an industrial city. She wrote a letter to Mrs. John, a friend in Prineville with whom she corresponded for many years, dated 6 May 1934 from Niagara Falls. In this letter she mentions teaching in the government sponsored pre-school. Alice Day Pratt, Niagara Falls, correspondence to Mrs. John, 6 May 1934, Crook County Historical Society, Prineville, Oregon. William wrote that his father, Julius, moved to Buffalo, New York in 1927 to teach at the university during which time 
she found nine months employment as an assistant in the "'Emergency

Nursery School,"' one of President Roosevelt's New Deal projects. Envisaging the young children to be "warmed and fed and made glad in sunny rooms as I had known the privileged tot of an earlier day to be cared for, "she "little dreamed of the coils of red tape and the mazes of science that would obstruct the realization of such a dream" where the children were "experimental 'material"' about which the teacher continually gathered data regarding the child's height, weight, temperature, and eating and toilet habits. ${ }^{163}$ Alice found herself, and the other prospective teachers, being lectured by a supervisor who had no knowledge of preschool theory and practice nor did she have any experience with young children. The philosophy was the exact opposite of what she had experienced in Chicago almost forty years previously and Alice seems quite distraught by the rigidity of her new school. Whereas the Chicago children were actively encouraged freely to explore their environment, these children were "pulled, jerked, pushed, mauled" into compliance. Teachers were forbidden to display affection, such as smiling; they couldn't call a child "dear;" "severing the "'mother attachment"' was a primary goal. The sand table, which was never used for sand, became the clay table, and then was

his parents lived with him. William, (the elder) died in 1928 so Sophie moved to Niagara Falls where Marjorie was teaching. William Pratt, correspondence to author, 31 October 1996.

${ }^{163}$ Pratt, Teacher's Trek, 64, 67,73. In her manuscript she stated the years as 1935 (p. 73) yet in a letter to Mrs. John, written 6 May 1934, she stated she had been working in a "Nursery School job" in which she receives a Government check. This must be the same job as the one in Teacher's Trek because she mentions a new "Pre-school" philosophy and a supervisor who is just out of college "being the only one who has studied this peculiar system." Alice Day Pratt, Niagara Falls, correspondence to Mrs. John, 6 May 1934, Crook county Historical Society, Prineville, Oregon. 
removed because it had no "aesthetic value." Excursions to the park were discontinued. Unlike her experience in Arkansas, where she engaged the children in both academic and social activities and encouraged their freedom of expression by interacting with them, these children were to be given materials with which to work but no direction in what to do with them. Alice was reprimanded several times for attempting to provide the children with some direction for the creative use of the materials provided. It comes as no surprise that Alice resigned. ${ }^{164}$ It would seem out of character for her to continue in a job where one's individuality, creativity, and independence were discouraged and not respected.

From her writings, one has the sense that Alice was a committed and caring teacher, that she worked very hard not only to make her students competent in "the three R's" but also to create in them an awareness and appreciation of art, music, and particularly, nature. She stated that she took her professional work "'hard' and seriously." ${ }^{165}$ While Alice desired a wellordered and disciplined classroom, she believed it should be the result of personal accountability as a socially responsible individual, not from the absence of personal beliefs, expression, and spontaneity. Her writings suggest that she envisioned a teacher as one who must provide direction and guidance, like a gardener whose plants are nurtured by sunshine and rich soil, free of weeds so they can grow and blossom. While a few might flourish with

\footnotetext{
${ }^{164}$ Pratt, Teacher's Trek, 64-73.

${ }^{165}$ Pratt, Three Frontiers, 57.
} 
little or no direction, children, like plants, are more likely to become unproductive without some intervention, guidance, and discipline. Her letters to her nephew William reveal a kind and caring character. He stated, "She could never have been unkind to anyone, but she certainly knew how to be firm." 166

Her writings provide no indication that she developed any close friends during these teaching assignments nor does she attest to community involvement other than in the capacity of teacher. During her three years in Arkansas, she would ride (horseback) into the woods, occasionally joined by some members of the mining families, and she spent Christmas 1907 with the Anderson family, owners of a nearby mine. While in Chicago she attended cultural events with other student teachers. Additionally, her descriptions of the natural environment during these teaching years are uncharacteristically minimal.

Alice's teaching certificate did open the world to her but the most profound and distant opportunity was yet to come. In 1910 labor problems shut down the coal mines, ending her employment. Assessing her situation, she wrote, "taking stock, I realized that I was tired - tired both by and of my work. There recurred to me the desire, latent and long-suppressed, to take the portion of

${ }^{166}$ William Pratt, correspondence to author, 30 July 1997. 
the earth's crust to which my citizenship entitled me and to experiment with it in terms of vegetable and animal species which held great attraction for me. ${ }^{167}$

${ }^{167}$ Pratt, Three Frontiers, 57. Beginning in May 1902, the United Mine Workers began a series of strikes in attempt to gain an eight hour working day, a ten to twenty percent pay increase, and recognition for the union. The first strike ended in October 1902; however, local union members continued for years to seek adequate compensation and working conditions. In Teacher's Trek, Alice referred to the UAW members in Spadra, Arkansas as "aggressive and belligerent." She does not take a position, stating "I am not able to speak of the rights and wrongs of the situations." (p. 22) Although she and William never discussed the topic, he speculated that in their beginnings, she would have been "wholly in sympathy with their efforts." William Pratt, correspondence to author, 30 July 1997. 


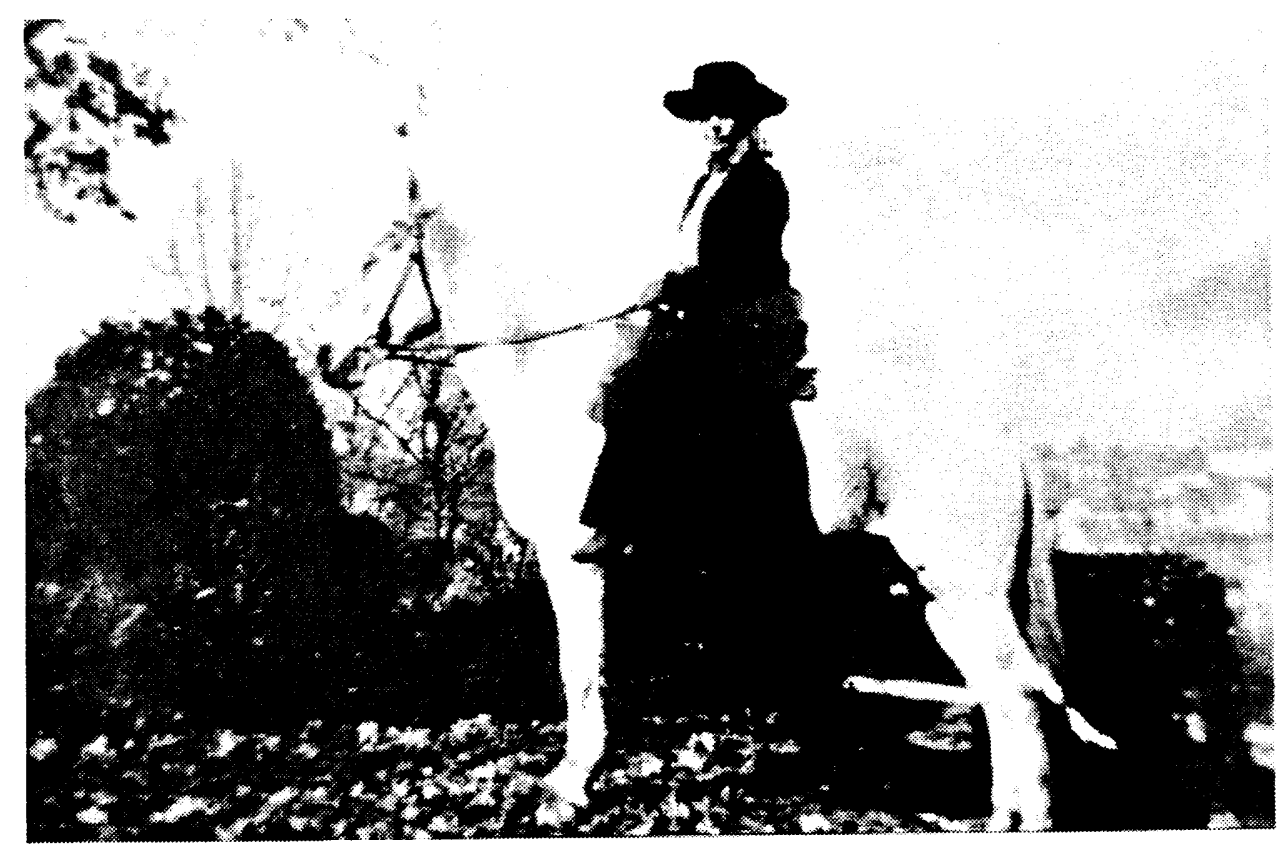

Alice in North Carolina

Courtesy of Crook County Historical Society 
Chapter 5

\section{HOMESTEADER}

Do I meet my own mother, young, in the experiences of Western women who endured a land short of everything but their own capacities? ${ }^{168}$

The Dry Land Homesteader

I've started to dry-farm

A piece of bend land sod

And if I meet no harm

l'll win or bust - by jinks.

Plow and harrow and disc -

Disc and harrow and plow:

Of course there is some risk

Until a chap knows how.

Campbell says they will grow

If seeds are put in right -

Depends on how you sow

With ground in proper plight.

And so I work all day:

At night I read his book -

I get no time to play

And hardly time to cook. ${ }^{169}$

Alice's life seemed to be going well. Her writings, both published and unpublished, testify to a close and affectionate family. She seemed to have reconciled herself to being single in an era in which most women married. She had a teaching career and was self-supporting. Despite these positive aspects, she was not quite content.

${ }^{168}$ Ivan Doig, Heart Earth (NY: Penguin Books, 1993), 17.

169 The Ismay (Ismay, MT), 1 May 1908 in Homesteading: A Montana Family Album, Percy Wollaston, with a Foreward by Jonathan Rabin (NY: The Lyons Press, 1977), xii. 
About the year nineteen-ten came to me -- teacher and spinster -- the conviction that Fate had paid me the compliment of handing over the reins. She had failed to provide for me the ideal relationship which alone is the basis of the true home, and I was by nature obdurate toward accepting anything less at her hands. When a youthful friend was surreptitiously chided for using the term "old maid" in my presence, the incident gave rise to thought. What now? I asked myself. Quo vadis, old maid? What will you do with life? Perhaps you have known the glory and dream. Will you subsist henceforth upon the memory thereof or shall life continue to be for you that "ecstasy" "nothing less than which is worth of the name?" 170

At age thirty-eight, Alice Day Pratt decided to become a homesteader.

Like so many other women who were looking for economic independence, a change in their lifestyle, and/or adventure, Alice, who liked doing interesting things, was lured West. Here women sought acceptance and freedom from class distinctions. They believed they would be free to live their own lives in their own way, "unhampered by what Mrs. So and So did or what Mrs.

Somebody or other expected" them to do and that the "broad-minded spirit of co-operation and helpfulness manifested in the West" would contribute to their success. ${ }^{171}$

This resolution must have caused a change in Alice's disposition because she noted that her "fellow teachers wondered somewhat that winter at my unaffected cheerfulness under certain afflictions that visited themselves upon us. They never dreamed that I was all the time afar on the prairies with the wind in my hair and the smell of new-plowed earth in every breath." 172 Once

\footnotetext{
${ }^{170}$ Pratt, Homesteader's Portfolio, 1.

171 A. May Holaday, "The Lure of the West for Women," Sunset 38 (March 1917), 61.

172 Pratt, Homesteader's Portfolio, 2.
} 
the decision was made, she needed to find out where land still was available. By this time, most of American land already was appropriated. She began her inquiry by seeking from the Department of the Interior maps designating unappropriated land. Additionally, she needed information on soil conditions and farming techniques. Materials describing farming techniques were easily obtainable. She studied literature from the Department of Agriculture to acquaint herself with "practical uses" of obtainable land. ${ }^{173}$ Deciding to raise chickens and wheat, her "farm was to be a true creation." 174 While she did not refer to any specific titles, it is possible she may have read books by one of the most influential authorities on dry-land farming, Hardy W. Campbell. He published Campbell's 1905 Soil Culture Manual which promoted the "Campbell method" of dry farming, "a peculiar blend of Calvinist theology and kitchen table science, in which capillary action was presented as a mystical nostrum, to be exploited by the 'dry farmer."' Campbell's book was green, embossed in gold, and on the cover was a camel with a banner across its legs stating, "'The Camel for the Sahara Desert, the Campbell Method for the American Desert." According to Campbell, the use of a disk harrow before plowing was essential. He wrote:

${ }^{173}$ Alice Day Pratt, "White Leghorns," The Atlantic Monthly 118 (July, 1916), 141. Although the following were published after Alice arrived in Crook County, promotional information describing the advantages of raising chickens in Oregon can be found in Advantages of Oregon: A Resource Book. (Portland: privately printed, n.d). Promoting the Hampton Butte area of Crook County, an article in The Bend Bulletin, 3 July 1913, page 8, stated that the sunny climate and dry winters were "well suited to poultry producing." Sunset Magazine, (August 1913) 418, contained an advertisement for Poultry Life: The Magazine of the Pacific Coast which was published in Portland, Oregon.

${ }^{174}$ Pratt, Portfolio, 3. 
For best results double disk the ground by lapping one-half, the object being to thoroughly pulverize and loosen the surface for a two-fold purpose. To loosen the soil and form a soil mulch to prevent the loss of moisture by evaporation as well as to break the hard crusted surface to promote a more rapid and complete percolation or soaking into the soil below of the early spring status... By the use of the sub-surface packer when the soil is in proper condition as shown [referring to a drawing], to a depth of seven inches; then with the Acme harrow we secure the fine loose mulch about two inches deep... (italics mine) ${ }^{175}$

According to Campbell, conservation of moisture resulted from loosening the topsoil and packing the subsoil, thus creating a "reservoir" beneath the surface. Unfortunately, this technique destroyed the sod in which native vegetation retained water within the soil. Sadly, this popular and highly publicized method of farming, the major principle being "rain follows the plow," was based upon erroneous assumptions and ultimately caused the failure of hundreds of dry land farmers and the destruction of thousands of acres of prairie lands. ${ }^{176}$

Probably in 1910, after deciding upon Oregon, because "public lands were seemingly most promising," Alice wrote to the State Superintendent of Schools requesting employment information and "obtained an introduction to the school directors of Athena, in the northeastern corner of the state where a primary position was vacant."177 She now had a job in Oregon, but because of low

\footnotetext{
${ }^{175}$ H.W. Campbell, Campbell's 1905 Soil Culture Manual (lincoln, Nebraska: H.W. Campbell, 1905), 16, 28.

${ }_{176}$ Wollaston, xi-xiv. Campbell also published a 1902 manual and Herbert Campbell published a 1907 edition.

${ }_{177}$ Pratt, Three Frontiers, 58. Athena is one half way between Walla Walla, Washington and Pendleton, Oregon in Umatilla County. Originally its name was Centerville but on 16 May 1889 it was changed to Athena. Lewis A. McArthur, Oregon Geographic Names $6^{\text {th }}$ ed. (Portland: Oregon Historical Society Press, 1982), 31.
} 
salaries in Arkansas and North Carolina, she had no money saved to afford a train ticket. Although Alice does not specify what "circumstances" brought her to New York in 1911, she did obtain a teaching position in Montclair, New Jersey and was able to save enough money for her ticket to Oregon and "incidental expenses." "So it happened that one day in early September [1911], with my vivacious brown dog on leash, ready for the baggage man, I boarded the through train from New York to Portland, Oregon. With the first movement of the train there dropped from me all the compulsions of my profession, all the nerve-weariness of the schoolroom, all the conventions of an old society."

In preparation for the move, Alice "devoured the history, geography and everything I could lay my hands on about my new home. I knew it all by heart." In Three Frontiers, she wrote a lengthy description of Eastern Oregon including the geological evolution where "'Little Eohippus' not only resolved 'to be a horse' but became one" grazing on the plains; the decision of immigrants to follow the Deschutes River, rather than risking the rapids of the Columbia River at The Dalles, to the junction of the Ochoco and Crooked rivers; and the

${ }^{178}$ Pratt, Three Frontiers, 58. William Pratt wrote in his journal on 31 December 1911 , "Alice went to New York early in the year intending to conquer the town with her literary work, and had a sad experience. Later she secured summer kindergarten work in Montclair, N.J. Went to Athena Oregon in September, after one week there, tried to override the School Board, and was dismissed, is now at Stanfield Oregon." (William Pratt papers, photcopy, original journal is in the possession of Walden Pratt).

${ }^{179}$ Pratt, Three Frontiers, 61. Although she does not name this dog, quite likely it is Bingo, the same one she owned when she began homesteading. While she mentions having a dog in Teacher's Trek, she does not indicate how important the dog is to her. From this point on, in Three Frontiers and particularly in Homesteader's Portfolio, her dog(s) are constant companions and friends. After she moved back to New York, her letters to her nephew William frequently contained references to her dog Max. 
way of life in Prineville: lucrative cattle ranching. ${ }^{180}$ Alice was optimistic that her farm would be "a true creation."181 Her readings on the High Desert however, did not prepare her for the harsh realities of life as a homesteader, and owner of chickens and a herd of Jersey cows.

\section{ARRIVAL IN OREGON}

After four days aboard the train, Alice arrived in Athena to begin teaching in the local school; however, the tenure of her employment was cut short by her social activism. Here again, as when she taught the African-American teachers, Alice demonstrated her resolve to do what she believed to be just even though her actions were not popular and/or resulted in adverse consequences. In this situation, her "sense of justice was seriously outraged." She supported a young teacher from Kentucky who, as she was to begin teaching in the Athena grade school, was informed by the principal that she was not needed. Two teachers had been hired for the same position so the school board chose to release the younger, even though she had been

${ }^{180}$ Pratt, Three Frontiers, 58-60.

${ }^{181}$ Pratt, Homesteader's Portfolio, 3. Regarding her use of the term "Little Eohippus," she may have been referring to the fossil beds in the John Day River Valley, near John Day, Oregon. They were discovered by Thomas Condon in 1862. Condon, who garnered national fame, used his findings to support belief in Darwin's relatively new theory of evolution. Condon wrote "The Rocks of the John Day Valley," which was printed in the Overland Monthly (1871). Although it is not know for certain if Alice read this article, it seems possible that she could have. Alice was a firm believer in Darwinian evolution based upon observations of nature and her readings of science. In a letter to William she referred to Huxley (probably Julian) and (H.G.) Wells as two of her favorite authors. She became interested in paleontology and geology while living in South Dakota, where she played at the base of Miller's Peak (later called Piedmont Butte). Her neighbor Mrs. Ellerman and a child, Myrtle Miller, found some "'funny stones"' which were excavated and put on display. Not long afterwards, noted paleontologist Othniel Charles Marsh visited the area. 
hired first. When the school board refused to retain the young teacher, Alice went to each teacher in an attempt to protest the unjust treatment and petition for reconsideration. Unfortunately, the response, reluctance by the other teachers to become involved, came as quite a shock to Alice. Realizing she now was known as one who incites rebellion, Alice chose to resign "as a protest against the decision of the board against my friend." Although she legally had thirty days to teach, the board replaced her immediately and indicted her on "half a dozen charges involving prodigious offenses against the law which I had practiced during my two weeks of occupation, summoning me to make defense or accept dismissal." ${ }^{182}$ Contrary to popular opinion, the West is not always a place of broadmindedness and acceptance. Westerners did not always welcome those championing social justice. As a homesteader, Alice occasionally would experience intolerance due to her individualism.

Fortunately, by the next month, October, Alice found employment in the four-year-old, private Stanfield irrigation project in Umatilla County in northeastern Oregon. The time at Stanfield was "a bridge to a new life" which enabled her "to be self supporting while I set myself up as a farmer." ${ }^{183}$ Those living here were examples of success and prosperity. Their irrigated farms yielded abundant crops of berries, fruits, vegetables, and alfalfa as well as flocks of sheep and chickens. Alice's compassion for animals and aversion to killing them, even for food, a constant theme throughout her writings, is a trait

\footnotetext{
${ }^{182}$ Pratt, Homesteader's Portfolio, 17-20.

${ }^{183}$ Pratt, Three Frontiers, 58.
} 
which sets her apart from most homesteaders. Whereas the sight of sheep grazing evokes serene pastoral images for many people, Alice was "harrowed by the sight of sheep gashed all over by the shearing machine." She saw "little lambs handled as if inanimate," and "suffered sad disillusionment" as she learned "what the wholesale raising of 'meat' entails." ${ }^{184}$ The landscape was another new feature which took some effort to appreciate. At Stanfield she encountered for the first time, the "strangely colorless landscape - gray sky, gray hills, gray sagebrush tracts" and the volcanic ash soil of Central and Eastern Oregon, quite unlike any landscape she had known in Minnesota, South Dakota, Arkansas, or North Carolina. ${ }^{185}$

Alice met another teacher, a single homesteader from Dakota "of Bohemian parentage", with whom she developed a close and lasting friendship. Her friend claimed a relinquishment on the Hermiston Project, a few miles from Stanfield. As many teachers did, and Alice would later do, this woman slept periodically in her cabin to fulfill the letter of the law requiring residence. Typical of many women, and unlike Alice, this friend's claim was adjacent to her brother's (and his wife) and, undoubtedly, the three worked both claims. Alice spent several weekends at her friend's home where she was witness to "the activities of the young couple - her brother and his wife the weary and endless labors, the adaptations, the privations and hardships, the soaring hopes and the repressed despairs of the beginning

\footnotetext{
${ }^{184}$ Pratt, Three Frontiers, 63.

${ }^{185}$ Pratt, Homesteader's Portfolio, 21.
} 
homesteader." 186 She learned much about dry-land farming, raising

livestock, and raising chickens. Alice found this location quite appealing. She made friends. She had a job. However, the land was not free. Farming here demanded even more money which would necessitate a loan. "If I borrowed money - 'so might I win, so might I lose.' I was unwilling to begin with a risk." ${ }^{187}$ She continued to seek a claim to public land.

During Thanksgiving weekend, 1911, while attending a state teachers' association conference in Baker, Oregon, Alice's life was forever changed. She received notice from her "locator" that he had found a piece of property in Crook County, Central Oregon in which he thought she would be interested. Securing "parole" from the disapproving hierarchy of the conference, she "departed with great glee" on the night train for Prineville, "the land of promise."188 Because there was no train from Baker to Prineville, Alice traveled first to The Dalles, transferring to Redmond and then, by the "whitemoonlight" took an "auto stage" the last twenty miles through the spectacular Crooked River valley to the "wonderfully scenic" Prineville. ${ }^{189}$

"Thanksgiving Day nineteen-eleven! It should appear in red letters in my chronicle - the day that I attained El Dorado." Her locator, "an interesting young engineer, enthusiastic, crammed with the facts I wanted, human, and

\footnotetext{
${ }^{186}$ Pratt, Homesteader's Portfolio, 38.

187 Pratt, Three Frontiers, 63.

${ }^{188}$ Pratt, Homesteader's Portfolio, 23.

189 Pratt, Homesteader's Portfolio, 24-25 and Three Frontiers 65.
} 
likable" introduced her to the site, in the midst of sagebrush and livestock

country, which would become her home. ${ }^{190}$ It was love at first sight.

I felt no hesitation. It was predestined. It was mine. For the first time, with the[Friar's] butte and the Maury Mountains at my back, I stood beneath a cone-shaped juniper and looked across the still-luminous valley and the river to those other mountains that were for so long to feed my eyes with their changing colors of slaty-blue, rose-purple, and amethyst. This juniper, for its beauty, should be my dooryard tree, I decided, This view should name my place and the name should be Broadview -- and so it was. $^{191}$

${ }^{190}$ Pratt, Homesteader's Portfolio, 25.

191 Pratt, Homesteader's Portfolio, 27. 


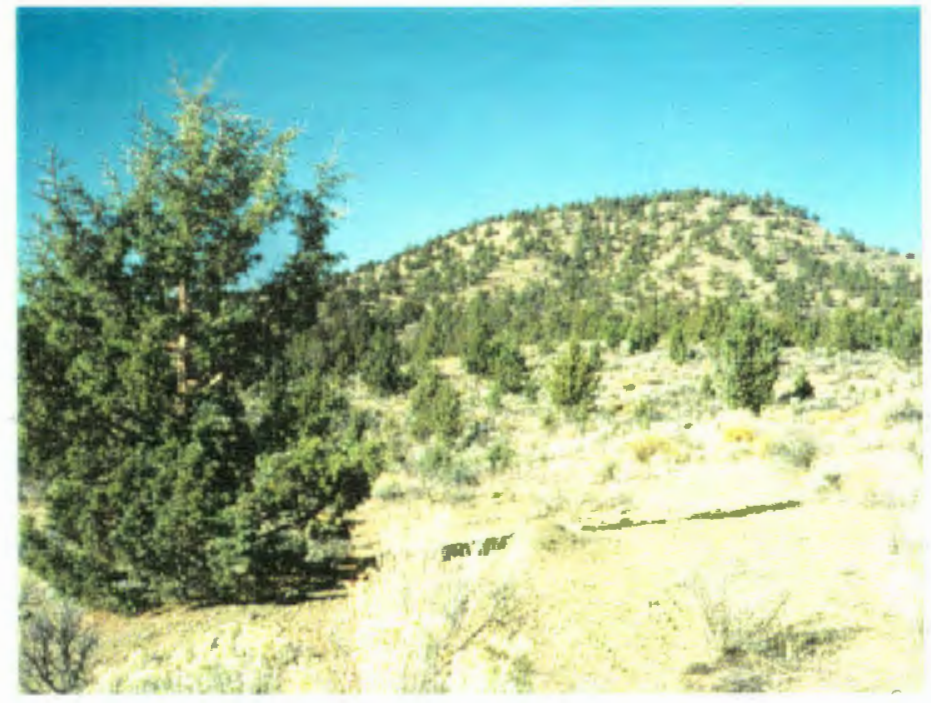

Friar's Butte from Alice's property Photo from author's collection 


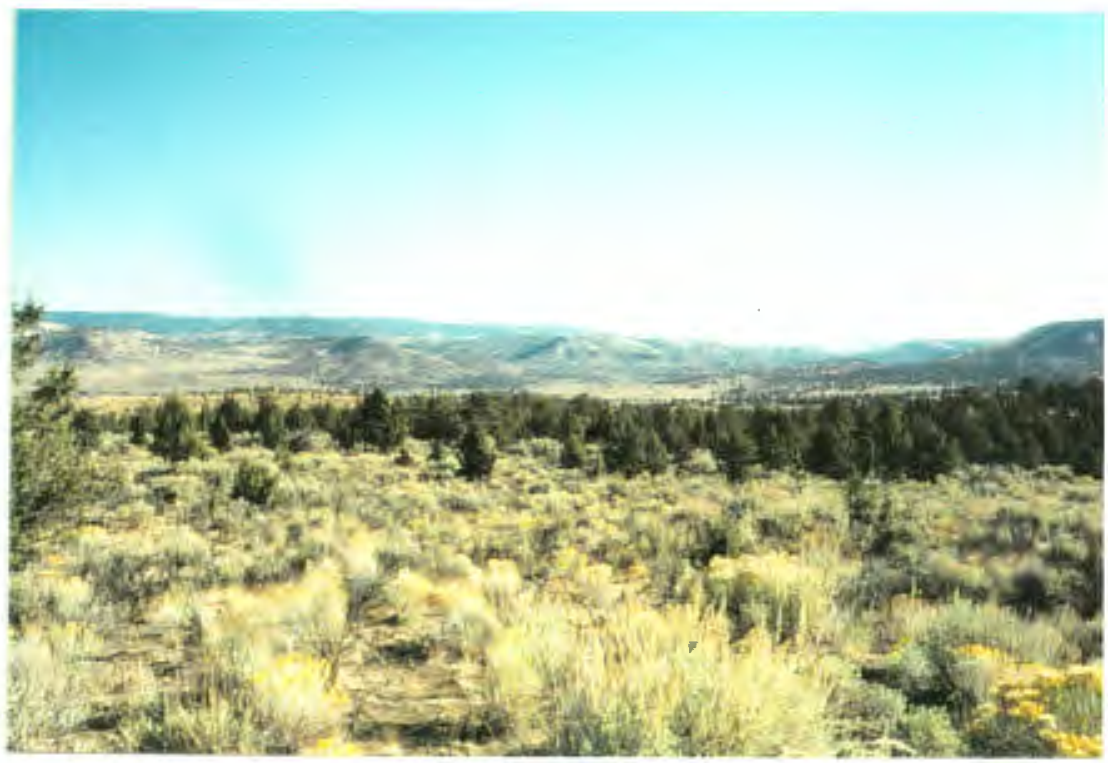

Maury Mountains from Alice's property Photos from author's collection

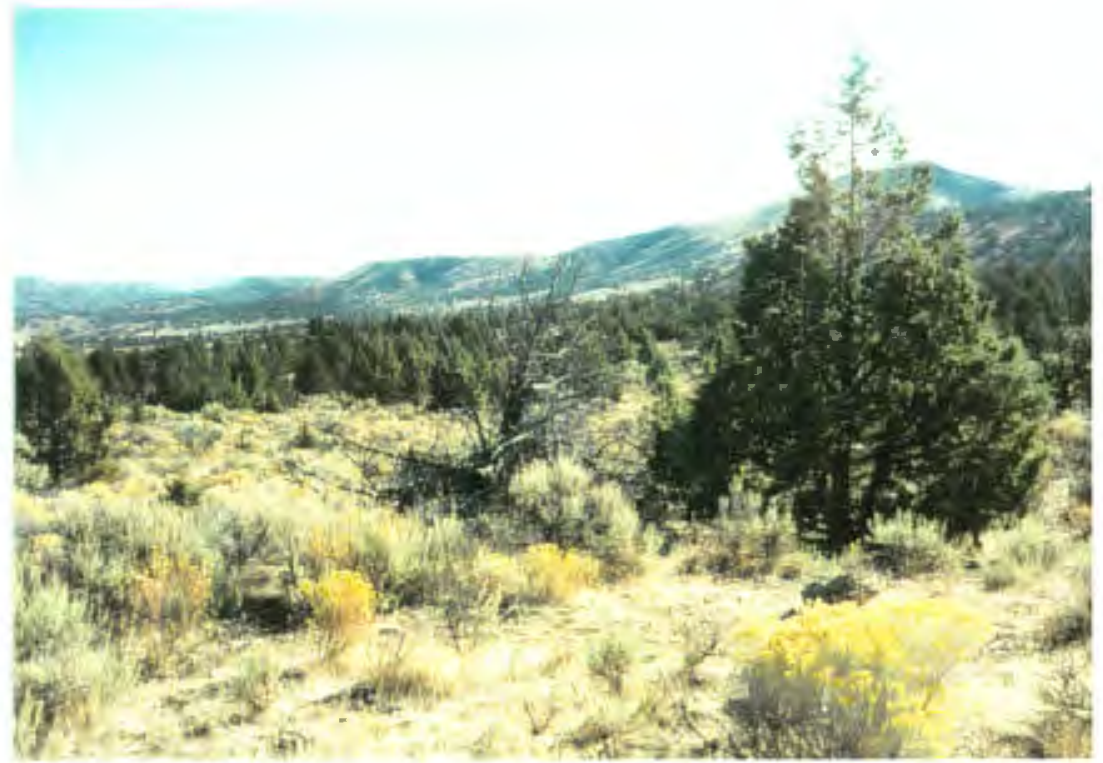


Following her introduction to Broadview, Alice spent Thanksgiving evening

at Bonny View, the family farm of Otto Gray, eating cake and ice cream and playing games with her soon-to-be neighbors. ${ }^{192}$ Although she was not the first single woman to homestead in the area, Alice probably was perceived as someone unusual. During the evening, Jessie Gray, who yearned to see more settlers in the Prineville area, expressed her displeasure that the locator was bringing in so many bachelors. At that moment the neighborhood began choosing suitable bachelors for Alice. It is interesting to note that she wrote, "But alas and alack! you (sic) may lead a horse to water ... they never induced their bachelors to drink." ${ }^{193}$ While this statement may cause one to wonder if she had some misgivings about her own singleness, she probably was referring to, and applauding, the independent spirit of these men. ${ }^{194}$

192 In her writings, Pratt used pseudonyms for her characters. Long time residents of Prineville have attempted to match the pseudonyms with the real person. In a letter dated 28 April 1931 to Grace Knox she mentioned the use of pseudonyms as the best way to present the names if the manuscript she was preparing should be published. At this point, however, she identified only "the lady of Bonny View." Since the names of homesteads are not changed, I chose in this case, to use Otto Gray's name. Today the farm retains the name Bonnieview (changed from Bonnie View) although it is no longer owned by a member of the Gray family. For further information about homesteads and who owned them, see Beverly Wolverton, A Hundred and Sixty Acres in the Sage: Homestead History of the Immediate Post Area (Post, Oregon: Beverly A. Wolverton, 1984).

${ }_{193}$ Pratt, Homesteader's Portfolio, 28 and Three Frontiers, 67.

194 One again is confronted with inconsistencies in her writings. In Teacher's Trek, (p. 40) she wrote, "Each school year is exciting to the bachelors, though only one has succeeded in persuading a teacher to become a Basin housewife. (The struggles of the Basin bachelor to procure a partner make a romantic story. They are well nigh reduced to the barbarous practice of descending upon the iowlands and carrying off their brides by main force)." It is possible that she was referring to Robert Demaris and his wife Mary Baker Demaris. Robert, a homesteader in Conant Basin married Mary, a school teacher and homesteader, in 1913. For a while they maintained two homesteads. In 1928 the couple moved to Riverside Ranch. Both ranches were on the west side of Friar's Butte from Broadview. Alice and Mary became good friends. See Wolverton, A Hundred and Sixty Acres in the Sage and Crook County Historical Society, The History of Crook County, Oregon (Dallas, Texas: Taylor Publishing, 1981), 98. 
Later, Alice did meet the surrounding bachelors and they "were something for any lone woman to think about. Some of them were of great and chivalrous service to me. Some of them expected a form of social service in return, for which I had neither time nor inclination." ${ }^{195} \quad$ Every Sunday during the two years she taught in Conant Basin she walked and/or rode her horse Fly, the twenty-mile round trip from her rented home to Broadview. During this time she wrote of one gentleman, a "handsome Frenchman" who began spending Sunday afternoons with her. He would bring her a single vegetable as a present and told her he would take good care of her "'stalk,"' referring to her chickens, dairy cows, and horses. She had no particular dislike for this gentleman but neither did she want to marry him. To discourage her friend's attentions, she changed her trips from Sunday to Saturday .

After he had called twice and found me absent, he took the hint. He was very grumpy for a time but in the end became a friendly neighbor. He wasted no more vegetables on me. It takes time to establish a modus vivendi with these single people and to convince them that a woman may really wish to be independent. ${ }^{196}$

This system of "courtship" must not have been uncommon. Anna Steinhoff, a single homesteader near Christmas Valley in Lake County, directly south of Prineville, described a similar situation in which a bachelor neighbor arrived with a freshly caught rabbit. After giving an account of the hunt, followed by "the talk of sensible things," he "drifted off" to the subject of

195 Pratt, Teacher's Trek, 44.
${ }_{196}$ Pratt, Teacher's Trek, 44. 
marriage during which she "was honored with a proposal and he with a refusal." 197

Like Elizabeth Corey, Anna Steinhoff, and others who cherished their independence, asserting her desire to remain single allowed Alice to enjoy social events and the friendship of the neighboring bachelors. They would come calling "to exchange the time of day." She enjoyed their conversations, especially when they talked about the "lore of the New Land" -- weather, cattle ranchers, and spring planting. Going on walks and riding horseback, she developed a "comradeship" and "a frank and stimulating acquaintanceship." She likened this comradeship to a "second childhood" in which one is less concerned with male/female relationships, thus liberating each to work and play together "in greater freedom of thought and feeling." In such a relationship, one's mind is unencumbered to explore and enjoy the interesting circumstances of life.(italics mine) ${ }^{198}$ Here, again, Alice affirmed her belief that one must actively pursue life rather than passively allow events to happen. She did note, however, what could be considered an undesirable aspect of such relationships. Once she established the fact that she was not interested in marriage, "there must be no appealing assistance on the ground of femininity." ${ }^{199}$ Thus, she would be on her own. When she did appeal for and receive help, it often was not in a timely manner.

\footnotetext{
197 Allen, 36.

${ }^{198}$ Pratt, Homesteader's Portfolio, 72 and Three Frontiers, 89.

199 Pratt, Teacher's Trek, 45.
} 
For her, platonic relationships were fulfilling and meaningful. She did,

however, betray herself by admitting to having romantic feelings for "Ben

Franklin." ${ }^{200}$ Walking home after a box social, at which she ashamedly placed her humble box amidst other beautifully embellished creations, she heard Ben walking behind her. He walked her home during which time they laughed about her "ignominious failure." After he left she wrote in her journal, "What sort of old maid am I anyway that I can't walk home in the moonlight with an attractive boy without tingling from head to foot! Good reason why devoted hermits segregate themselves. In the peace of Broadview I haven't felt this way for lo these many moons." 201

The day after Thanksgiving, 1911, Alice returned to Prineville where she filed claim to "the southeast quarter and the south half of the northeast quarter and the lot one - Section Four, Township Seventeen, Range Nineteen East, Willamette Meridian." She noted that legally her claim was one hundred sixty acres, however, due to the curvature of the earth, she actually would own only "one hundred fifty-nine and some one-hundredths" acres. ${ }^{202}$ After her papers were processed at the land office in The Dalles, she received notice

${ }^{200}$ This is a pseudonym for a local bachelor. Residents have speculated that she was referring to Raymond Smith whose homestead was adjacent to and directly west of Broadview.

${ }^{201}$ Pratt, Portfolio, 92. It is not known for certain if Alice was romantically involved with anyone prior to moving to Oregon. Her nephew Walden thinks she may have had a few suitors and vaguely recalled "a story about a rather deep disappointment" in one of Alice's suitors "introduced her to his new fiancée without preparing her for the surprise." Since there were few bachelors in the Black Hills, she had little opportunity to meet eligible men. Walden suspects that a combination of independence, intelligence, and high standards may have either eliminated or scared off many prospects. If she ever had any regrets about being an "old maid," Walden believes she never expressed them. Walden Pratt, correspondence to author, 31 October 1996. 
that she had three years to fulfill the residence and improvement requirements after which she would receive title to her land.

Surely, she must have been excited and eager to begin working her claim, but she still had several months of her teaching contract remaining. Although she taught at Stanfield for the entire school year, she omitted any references to her classroom experiences. What she does describe is her "very first step in an independent agricultural career" and "business venture:" raising chickens. With the help of her friend and her friend's brother, she borrowed an incubator and bought "something over a hundred" White Leghorn eggs. The ever mindful "mother hen," Alice carefully monitored the temperature and daily turned the eggs. Fluctuating atmospheric temperature plagued her. One night when the temperature plummeted, she built a fire to heat pans of water which she placed under the incubator. Another day, while several miles from her home, a sudden heat wave sent the incubator soaring above one hundred ten degrees, threatening to cremate the embryos. Terrified, Alice covered the eggs with wet towels. To her relief, sounding "so much as a corn popper at its crisis," all one hundred plus eggs cracked, discharging a multitude of feathered creatures. ${ }^{203}$ Alice wrote about this experience in an article entitled "White Leghorns," her second published work, which appeared in the July 1916 issue of Atlantic Monthly. Later, she incorporated it into Homesteader's Portfolio and Three Frontiers.

\footnotetext{
${ }^{202}$ Pratt, Homesteader's Portfolio, 28 and Three Frontiers, 67.

${ }^{203}$ Pratt, Homesteader's Portfolio, 38-41.
} 


\section{A NEW BEGINNING}

On 21 June 1912, almost two years after her decision to homestead, "the Pilgrim, on this fateful morning, began her homestead residence." 204 With her were "a shaggy brown dog" (Bingo), three splint baskets containing the four day old "ninety balls of straw-colored down" White Leghorn chicks, a trunk, and a tent. "Nine months before, the Pilgrim had stood in a palatial waiting room in New York City, buying her ticket for Portland. Now she was at home (italics mine). One hundred and sixty acres lying about her were already entered in her name in Uncle Sam's records." 205

Word of Alice's arrival spread via telephone. Early the next morning, almost before she had time to wash her face and drink a cup of coffee, neighbors turned out to greet her. Two young bachelors, bringing a pail of warm milk, offered to stretch her tent and supplied her with essential information about the area. The next to arrive were her immediate neighbors who had been using her newly claimed land as free pasturage. Another visitor offered to plow her first twenty acres "'at the going price' as soon as he should have broken a young horse for which he was about to go the mountain."

Since another would be hauling wood, before threshing time, for his own

${ }^{204}$ Again, another discrepancy exists. In Homesteader's Portfolio (p. 47), she gives the date as 21 June, however in Three Frontiers (p. 69), she gives the date as 4 June. I have chosen to use 21 June because Homesteader's Portfolio was written in 1921, ten years after her arrival, much closer in time to the actual event. Alice referred to herself as the "Pilgrim" in "White Leghorns," Homesteader's Portfolio and Three Frontiers and as "Teacher" in Teacher's Trek. In her other four articles appearing in Atlantic Monthly, she wrote in the first person.

${ }^{205}$ Pratt, Homesteader's Portfolio, 48. 
house, he promised to deliver lumber for her tent house. Grateful for their offers, Alice soon discovered that her neighbors were not as willing to help as they appeared. The tasks for which they offered assistance remained in the future. Her immediate needs, such as how to transport her furnishings, a cot and chairs from the post office only three and one half miles away, met with "glances of puzzled consideration" and no offers to help, even though three teams of horses were tied nearby. Noting this behavior seemed to be common, Alice recalled the truth of the phrase another local, "the Old Oregonian," made about easy promises to the future and unresponsiveness to the present. ${ }^{206}$ These offers probably were given in all sincerity, however, individual time constraints and her inability to reciprocate may have been the cause of her disappointment.

During that week she made the first of many trips to the store and post office. She discovered the best way to carry loads "a goodly distance" was upon her shoulders and that forty pounds was her limit.

Unaccustomed to the local fauna, she awoke the third night to a saddled horse standing directly in front of her tent. Fearful of who might be there, she grabbed her gun and awaited potential developments. After a few hours the horse left and she went back to sleep. The next day, as the horse munched the nearby grass, its owner appeared. He had lost the horse the day before as he was following some livestock on foot! A few evenings later, she heard unfamiliar sounds which resembled the shouts of boys on a ball field. She 
soon discovered the sounds belonged to coyotes. Bingo, who had run out to investigate, came racing back to the tent with one coyote at his heels. ${ }^{207}$ Not only did Alice's tent provide shelter for herself and Bingo, it also protected her brood of chicks from coyotes.

It seems surprising that Alice, by her own admission, had an "idle" summer. One would think she would have been hard at work trying to get her fields cleared, crops planted and a house built, yet, in her naiveté, she believed she had everything under control. She thought she had made arrangements with the neighbors for hauling lumber, fencing, and plowing twenty acres so she needed only to tend her flock of chickens. She made a chicken house by digging a cave in a ridge bordering her field. She felled fifty junipers from which she constructed the walls, and then enclosed a run with wire. She took time to socialize, becoming close friends with Lily and Vicie Knox. This friendship, particularly with Lily, would continue into the late 1950 s. $^{208}$ In addition, she "found much time for meditation beneath the juniper." Reflecting upon her situation, she wrote in her journal

In this primitive existence one learns not to deplore the necessity for hard labor, but to find a daily wonder in the abundance of the first necessities of life - the brimful spring of icy and crystal water, the easily acquired and abundant firewood, the essential groceries brought three miles upon one's shoulders. It is when one is weary beyond words, hungry and athirst, that warmth and rest and food and drink yield, for the moment, the purest pleasure of existence.

${ }^{206}$ Pratt, Homesteader's Portfolio, 49.

${ }^{207}$ Pratt, Homesteader's Portfolio, 50-52.

${ }^{208}$ Alice used the pseudonym "Nash girls" for these two women. Again, as in the case of Otto Gray, I chose to use their real names since there her friendship with these two women was an established fact. Among the letters contained at the Crook County Historical Society, are many written to Lily Knox, the last one dated 6 January 1957. 
Through the absence of all conveniences, one learns from day to day what are the superfluities, and also what are the foundation stones of civilized existence. And in this simple life - the extreme opposite of coöperative industry - wherein one performs every necessary service for oneself, how one's heart goes out to the professional and perpetual toilers of the world... 209

Alice is unique, not only because she is one of the few women homesteaders who left written accounts of her life, but also in the style of the accounts. Only a small number left journals because most did not have the time to do so. The arduous work compounded with employment frequently left one too exhausted at the end of the day. Alice made the time to reflect and to write. This passage appears to romanticize homesteading yet it does reflect her passion for her choice of lifestyle. This passion for Broadview and homesteading remained throughout her life. After she moved back to New York, her letters to friends in Prineville frequently included references to her desire to return to Broadview and how she missed it.

\section{A HOME OF ONE'S OWN}

One of the first pressing duties of the homesteader was to construct a house. Lumber is scarce in the high desert. While juniper is plentiful, it is too hard, too small, and too gnarled for building. Pine, the most useful, had to be transported. Most houses were small and simple, often a box frame with board and batten or shiplap exterior. Depending upon the size and needs of

${ }^{209}$ Pratt, Homesteader's Portfolio, 69. Alice included in her book exerpts from her personal journal. 
the family and its economic status, most ranged from ten feet by sixteen feet to sixteen feet by twenty feet, with twelve feet by fourteen feet and twelve feet by sixteen feet being most prevalent. Commonly, foundations were of two types: field stones or two or more logs laid over a pit to which floor planking was nailed. The pit was used as a cellar where root crops and canned foods were stored. Roofing materials customarily were Ponderosa pine shingles. However, tarpaper and "rubberoid" also were used. "Snug as a bug in a rug" the settlers were not. Their homes were drafty, allowing the cold and wind to penetrate. ${ }^{210}$

Besides acquiring knowledge of farming from her friends at Stanfield, Alice "learned here to appreciate the excellent qualities of the 'tent house' - so inexpensive, so tough and so cozy." ${ }^{111}$ The tent was perfect for summer days but as fall approached, the temperature dipped and ice began to form. She was eager to begin building, especially because she had signed a contract to teach at a local school and wanted to be "cosily housed" (sic) before opening day. Optimistic that the offers of help were sincere, she soon was disappointed. Her neighbors made trips to the mill to get their lumber but no one wanted to make a second trip to get her lumber. "John Porter" did deliver her lumber on 31 October 1912, four months after her arrival. Within a week her tent house was completed. ${ }^{212}$ Here she lived quite adequately that entire

${ }^{210}$ Allen, 40-43.

${ }^{211}$ Pratt, Three Frontiers, 62.

${ }^{212}$ Locals believe Porter to be Bob Demaris who married Mary Baker. Their daughter, Mary Meda Demaris Wilson, told me that Alice made her baptismal dress. Although Mary 
first year. The seasonal weather conditions seemed not affect her cozy habitation. Of hail storms she wrote, "when there falls a bombarding and unmerciful visitation of hail that, perchance, beats holes in the shingled roofs of your neighbors, it bounds harmless from the yielding tent." Winter temperatures fall well below freezing and snow covers the High Desert ground, yet "furnished with a vigorous little heater and a pile of juniper wood," it was "difficult to find a cosier (sic) habitation." ${ }^{213}$ What she did not mention in this passage was that her wood supply was one quarter mile from her tent and some days the tent was not so cozy. One January morning she awoke to discover the stove had gone out. Her hands were so cold, she had difficulty dressing. She left on her three and one half mile walk to school through unbroken snow drifts with only "a frozen biscuit for inward cheer... in acute pain at the start with fingers and toes." ${ }^{114}$ Regarding winter weather, her brother Julius gave the following brotherly advice, "I hate to think of you and your 6 mile walk if this [cold] has fallen upon Oregon. For heaven's sake, do keep a good bottle of whiskey in your tent to be used sometime when you get well chilled coming home from school. I don't feel guilty in this advice in the light of your usual temperate habits in the past, and I really think it is most Alice left her homestead, she stayed her last night in Post at the DeMaris house.

\footnotetext{
${ }^{213}$ Pratt, Homesteader's Portfolio, 88-89

${ }^{214}$ Pratt, Homesteader's Portfolio, 93.
} 
essential that you have something." ${ }^{215}$ Again, during her second year, she "lay and shivered" in her "rocking tent house" during an early blizzard."216

The second year Alice taught school in Prineville, thirty miles from her homestead in Post. Here too she "procured" a tent house with an adjacent chicken yard. Each weekend she rode horseback the sixty mile round trip to Broadview until winter storms made the trip too difficult. By law, she was able to take a five month leave of absence, which she utilized at this time and did not return to Broadview until spring when she brought several teachers "for a night's camp" during which they envied her first crops and the beautiful landscape. ${ }^{217}$

Not until the summer of 1915, three years after her arrival, was Alice's house completed. Saving money from the sale of eggs, milk, butter, and from teaching school, she was able to pay "Andrew DeLong" and "Ben Franklin" to build her house.

My little house consisted of one room -- twelve by twelve-- facing east. The front, which was the long way of the structure, has a broad porch. Upon this porch opened a double door, and on each side of the door was a window -- two by four-- the long way being horizontal and the window letting down by hinges against the wall. Thus, in summer, it was possible to open the whole front of the house toward the east, with the awning-like protection of the porch roof. ${ }^{218}$

Her cabin probably was sparsely furnished. In 1972, when Clarine Silver visited the vacant house, she found "rusty remains of an old cook stove" a

215 Julius "Will" Pratt, Chicago, Illinois, correspondence to Alice, 8 December 1912 , Crook County Historical Society, Prineville, Oregon.

${ }^{216}$ Pratt, Homesteader's Portfolio, 112. 
small lidless trunk, a rocking chair, a narrow cot, and pieces of a poultry incubator. ${ }^{219}$ Prineville resident Cora Houston, who, as a child, visited Alice's house with her mother, recalled that "the cabin was small, and the room seemed to be mostly taken up by the incubator..."220

${ }^{217}$ Pratt, Homesteader's Portiolio, 113.

${ }^{218}$ Pratt, Three Frontiers, 113.

${ }^{219}$ Clarine Silver, "The Old Maid of Friar Butte," Eugene Register-Guard Emerald Empire, 23 April 1972

${ }^{220}$ Cora G. Houston, Prineville, Oregon correspondence to author, 8 August 1997. 


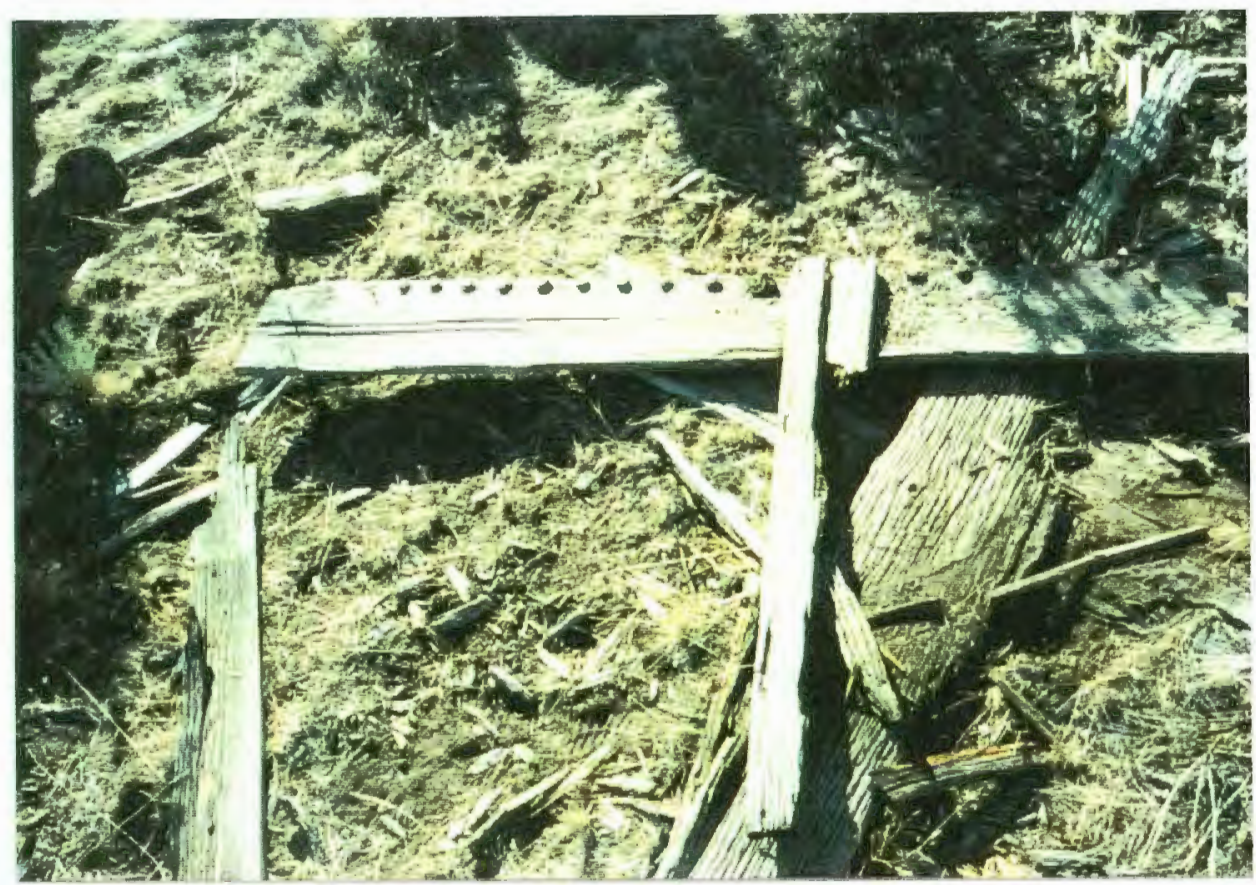

Probable remnants of her tent house. Photo from author's collection. 

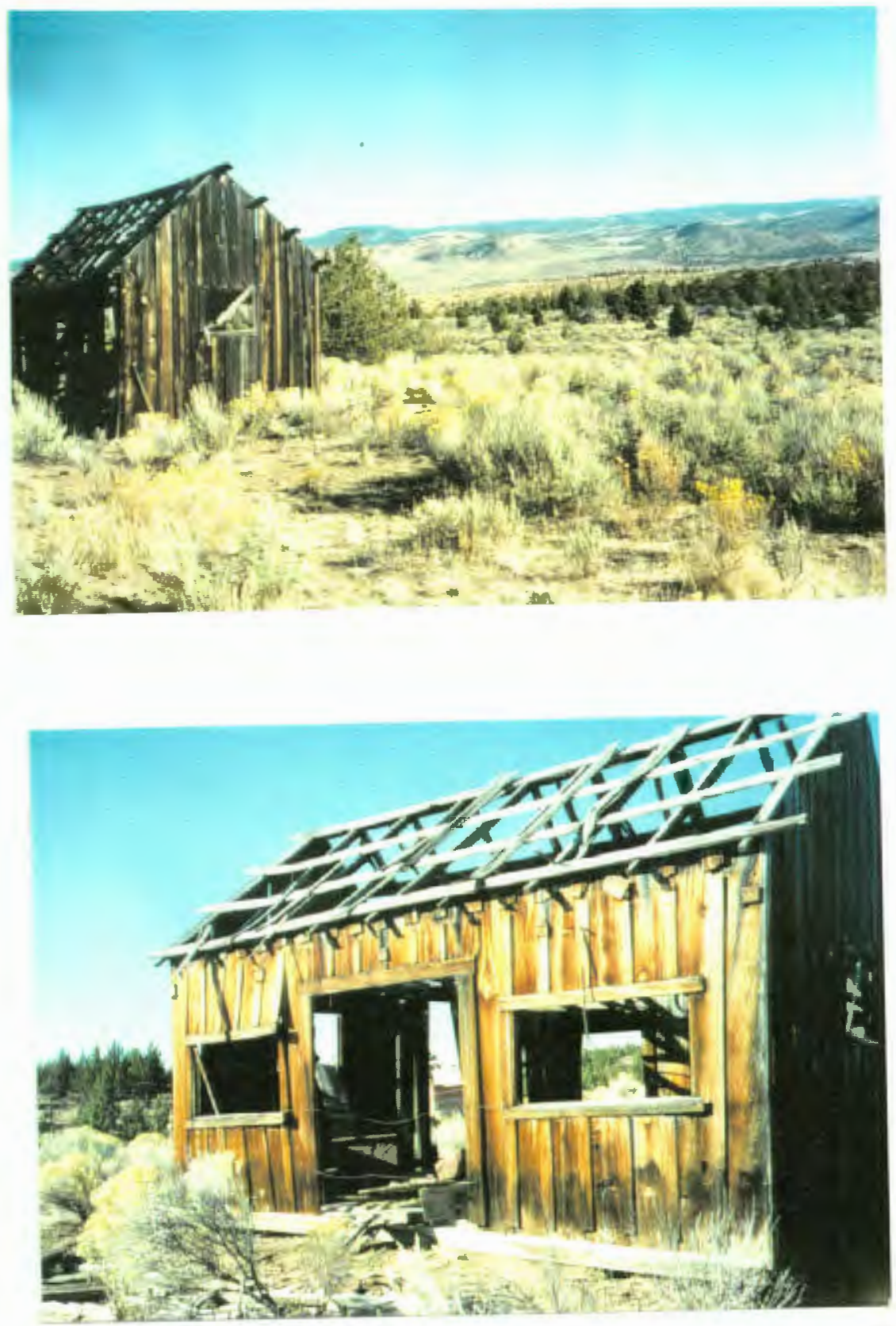

Remains of Alice's house, 1995.

Photo from author's collection 
“STARVE 'EM OUT"”

Alice again experienced disappointment when she tried to find help plowing and planting the required twenty acres. While everyone was willing to talk about farming methods and told her they were interested in seeing her prosper, no one offered to help. By October 1912 she advertised for workers but no one responded. To her surprise, she discovered an undercurrent of dislike for new homesteaders. One resident, the "Old Oregonian," remarked, "'The only way to deal with them homesteaders is to starve 'em out. Take it from me."'221

One charitable neighbor did wish to see her succeed. He appeared one late October morning and offered to clear her twenty acres, after his were finished. After some negotiating, they agreed upon a fee for his services. Upon further questioning she learned he lacked the necessary equipment and would have to hire an extra team for which he would need an advancement of fifty dollars, half the amount of money she had for putting in her first crop. "Some vestigial trait of shrewdness awoke and prompted the Pilgrim to bring forth pen and paper and take receipt for fifty dollars with details of the contract" which stipulated the land would be plowed and planted by 15 November. The gentleman did not uphold his side of the agreement. Alice chose not to dwell on this sad experience yet it did affect her attitude as "the death of buoyant hope, patient anxiety deepening into despair, doubt supplanting confidence, gratitude metamorphosed into resentment." In April 
she received forty dollars, a refund of her money less ten dollars for legal services. Her crop was not planted for another year. Her neighbors were more benevolent in the spring of 1913 and helped her plow her land. With the exception of the first plowing, her one acre garden was cultivated and planted by hand.

Alice's first wheat crop yielded an abundant harvest "without mishap." Her elation "dulled the edge of earlier disappointments and disillusionments." (sic) Taking advantage of a change in the Homestead Law which doubled the allowable acreage for those living in semi-arid regions, she claimed another one hundred sixty acres. Again she was confronted with the problem of finding someone to plow twenty acres. She became acquainted with a new homesteader and his wife and "presented the plowman with free pasture for his term of work." She dwelt upon all essential details of the work desired" and then "left the matter in his hands." Again, the field did not get tilled nor the wheat planted in a timely manner. In her journal, Alice wrote

My explanation of much of my difficulty along this line is that the labor of men in the country is reciprocal - each man in helping another is establishing a definite bank account for himself in time of need, and, on the same principle, failure to accommodate means retaliation when it may be most sorely felt. Frost came and came to stay. The ground was soon hard as rock and once more my seed wheat lay through the winter - a sad reminder of fruitless planning. ${ }^{222}$

${ }^{221}$ Pratt, Homesteader's Portfolio, 77.

${ }^{222}$ Pratt, Homesteader's Pontfolio, 120. 
Alice spent this winter at Broadview, penniless and in debt. The neighbor demanded payment for the partial work he did and the unplanted seed had to be paid for. She did not have enough firewood for the winter but neither did she have the funds to pay someone to cut any. She cut juniper and purshia, a desert shrub, where she could find it but that too ran out during a month long cold spell. In desperation, she burned her chopping block and the next day she burned her ladder. Fortunately, as she was about to burn her porch steps, a chinook wind melted the snow, revealing new sources of wood. $^{223}$

During the summer of 1916 , she had expected help with the wheat harvest but found it to be "an almost unknown quantity." So not to lose her precious crop, she cut it with a scythe during the night to avoid the heat. After cutting about two acres, a "human-hearted rancher" loaned her his idle old mower. She had not considered how she would rake the wheat and did not have a hayrake. Thankfully her friends, the Knox sisters, loaned her theirs. The next task was to stack the sheaves. Again, she had not considered doing it alone, and, although the task seemed impossible, she labored day and night until all twenty-five tons, one hundred thousand pounds, had been tossed and stacked! $!^{224}$

Alice's writings express anger and frustration at her neighbors for their lack of help. Mary Demaris Wilson stated, "I think when she worked in the coal

\footnotetext{
${ }^{223}$ Pratt, Homesteader's Portfolio, 120-21

${ }^{224}$ Pratt, Homesteader's Portfolio, 172-3.
} 
fields [as a teacher] and places like that, I think she was more readily accepted than she was as a homesteader. I always thought she expected more from the natives than they were willing to give." ${ }^{125}$

The "Old Oregonian" was not the only one from whom she experienced outright hostility. Her decision to raise Jersey dairy cows was regarded as quite strange in an area known for beef cattle. Ranchers are quite protective of their cattle. Gale Ontko stated that if a dairy bull mates with a beef cow, it causes a difference in the color of the offspring's hide. "Even today you get less money" for those cattle because "they don't look right" even though the meat tastes the same."226 "The introduction of Jerseys into the heart of beef country was quite a presumptuous act and was, to some extent, treated accordingly."227 According to Gale Ontko, "If someone is a little different, well, by golly, he or she is more or less ostracized by the community. They don't go out of their way to help. Been that way from the go."228 Ranchers' cattle broke her fences, tore her barnyard gate "to shreds," ate her precious hay reserved as winter food for her cows, and tore the cows loose from their "moorings in the shed."229 One spring morning she found "nineteen young steers, newly branded and half-way to their summer pasture in the Forest Reserve, were lying down there fully fed and satisfied by the growing crop.

${ }^{225}$ Interview by author, 21 July 1995, at Crook County Historical Society, Prineville, Oregon

${ }^{226}$ Ontko interview, 21 July 1996.

${ }^{227}$ Alice Day Pratt, "Jerseys," in The Atlantic Monthly 147 ( Jan. 1931), 57.
${ }^{229}$ Pratt, "Jerseys," 57. 
They belonged to a rich cattle man, who had hit upon this happy halfway station to rest and recuperate his stock."230

The cow problems began in June 1915 when she received, on her birthday, fifty dollars from a "good relative who had become interested in my curious way of life."231 She immediately purchased, for "the unusual price of sixty-five dollars," Bossy, a well pedigreed pregnant Jersey cow. Shortly after her arrival, Bossy delivered a healthy steer calf, which Alice named Psalmmy. Alice rejoiced in the antics of this new calf and, despite the counsel of her neighbors to "beef him" since "it's all he's good for anyway," and "what are you keeping him for?" she could not get rid of the calf.

Undoubtedly Alice's cows, particularly her bull calf, wandered outside of their own pasture. She makes note of in her article "Jerseys," that, Ann's Lad, "carries at least one bullet and several scars as souvenirs of visits outside his proper range." ${ }^{132}$

On 25 March 1915, perhaps in response to this "troublesome" calf, or perhaps in an attempt to acquaint Alice with the ways of cattle raising, her neighbor Joe Gibson caught and castrated the five month old calf. Alice sued Joe Gibson, Grover Gibson, Ralph Gibson, and Ernest Gibson for damages in

${ }^{230}$ Pratt, Teacher's Trek, 42.

231 Pratt, Homesteader's Portfolio, 124.

232 Pratt, "Jerseys, 57. Here she uses a pseudonym for her animals. In Homesteader's Portfolio she refers to her cows as Bossy and Psalmmy. It is not known what she really did name them. 
the district court in the amount of one hundred dollars. ${ }^{233}$ All defendants denied the allegations, claiming they in no way damaged the calf. The case went to trial and on 8 April 1916 the jury awarded Alice "the sum of (75.00) Seventy five (sic) dollars and costs" which were forty-five dollars and fifteen cents. $^{234}$ The case did not stop here. Gibson appealed the verdict to the Circuit Court on the grounds that "said complaint does not state facts sufficient to constitute a cause of action" against him. Again the jury filed in favor of Alice but this time for the amount of seventy-five dollars and costs of eighty-four dollars and seventy cents ${ }^{235}$ Still not content to settle, Gibson took this case to the State Supreme Court claiming that Alice's attorney had referred to him as "'A crook" and a "'rough neck'". Ultimately, Judge Duffy upheld the lower courts' decision but instead of seventy-five dollars, Alice received only thirty-seven dollars plus damages. ${ }^{236}$

Alice did not include this incident in either of her books. Instead, what appears is a description of how Bossy was stolen and taken to a slaughter house. Upon discovering the missing cow, Alice rode "in a blind fury" upon her horse Fly in an attempt to find the cow. When she found Bossy "well supplied with food and drink, recumbent and placid" in a pen awaiting slaughter, she

${ }^{233}$ Joe Gibson's property, and that of his sister Rose, were adjacent to Alice's on the south and east sides.. Joe's parents, John and Molly, were "squatters" who arrived in 1886. See Wolverton, A Hundred and Sixty Acres in the Sage.

${ }^{234}$ Pratt v. Gibson, Crook County Court Justice District 22, 1916, Salem, Oregon: Oregon State Archives, case number 9334, drawer number 3326.

${ }_{235}$ Pratt v. Gibson, Circuit Court for the State of Oregon, 1916, Crook County, Salem, Oregon: Oregon State Archives, case number 9334, drawer number 3326.

${ }^{236}$ Pratt v. Gibson, Supreme Court for the State of Oregon, 1916, Salem, Oregon: Oregon State Archives, case number 9334, drawer number 3326. 
summoned the local justice of the peace who refused to hear her case that night. The next day, the jury was loath to award her the cow without a witness. Additionally, the cow was unbranded, a serious offense in cattle country. Just when Alice thought she would not get Bossy, a neighbor drove up with Psalmmy in the back of his truck. After consuming his fill of milk, the calf looked Alice and emitted a loud 'b-a-a-a-w!'” in recognition. Alice rested her case. That both incidents, so close in time, occurred does not seem realistic. The former took place 25 March and the latter in May. Why she changed the story is not known. Perhaps she was simply exercising literary license. Perhaps she thought it would be more appealing to the 1921 reading public than a lawsuit over a castrated calf. Interestingly, the afterword of Homesteader's Portfolio, contains a reference to this incident. She wrote that after her return to Broadview, following a two year hiatus in the East, her calf was mutilated and that Bossy was "ruthlessly killed for straying into a neighbor's pasture over his down fence."237

\section{FARMER}

Farm work was arduous and oftentimes frustrating. Rabbits, a constant problem in central Oregon, devoured Alice's crop. One year they destroyed one-sixth and another year one-third. She tried sleeping outside, thinking that Bingo would chase the rabbits off, only to awaken to find Bingo curled beside her and the rabbits banqueting on her garden. She finally resorted to 
purchasing a twenty-two rifle but her lack of marksmanship skills resulted in painfully slow deaths of two unfortunate rabbits. A lover of nature, especially animals, she "was filled with horror and amazement at the thing that I had done. I shall remember those two rabbits as long as life is mine." ${ }^{238}$ She vowed never to shoot another creature and from then on oddly, resorted to poison.

Plowing her fields seemed to be a constant problem. Even after two failed attempts to hire someone to plow them, she contracted once more in the summer of 1915 with yet another person. Again this one failed to fulfill his promise. Thinking the work was "beyond" her, but "left in a lurch," she could not put off planting without facing ruin. Without a crop, she would have to buy feed for her chickens. With her horse, Fly, a borrowed horse, and a borrowed walking plow, and "much tribulation," she turned three acres. Only thirty-seven remained! Fortunately, her neighbor loaned her a riding plow. Adhering to a strict schedule, with "aching arms" that "almost refused to move and knees cracked with excessive exercise," she managed to finish the plowing and seeding. After completing this exhausting work, in typical style, she reflected back upon the "spiritual fruits" of the chore: the "rare leisure and opportunity to observe the sky, the shifting sun, the maturing season... to pity the poor

${ }^{237}$ Pratt, Homesteader's Portfolio, 179.

${ }^{238}$ Pratt, Three Frontiers, 117 . Here again is an inconsistency in her writings. During her first week at Broadview, when she heard the horse outside, she went out with her gun. Here, at least one year later, she said she bought a gun. In an interview with Mary Demaris Wilson, she told me "I don't think she ever owned a gun. She might have had a gun. You'd think she'd learn how to handle a gun. My mother did." Mrs. Wilson thought it odd that Alice did not protect her chickens and cows from predators by shooting them. 
evicted creatures of the soil - the dazed and paralyzed little mice and moles..."239

In addition to planting wheat and a vegetable garden, she had her chickens to tend. They had to be protected from hawks and snakes. Eggs needed to be gathered daily and then sold. Mary Demaris Wilson recalled Alice packing her eggs in a pushcart and walking about selling them. ${ }^{240}$ Although she had intended to raise chickens solely for the eggs, she did have to remove the "superfluous little cocks." Her neighbor "John Porter" came over one evening to help her kill them. She spent all day Saturday and Sunday plucking the carcasses. The next day, Monday before Thanksgiving, she went to town (probably Prineville) with "Ben Franklin" and "John Porter" where she sold all of her chickens. Although she does not mention it, butchering the chickens must have been quite a difficult task for her, considering her love for animals.

At times, when she lived away from Broadview, she took her flock of chickens with her. Don Brummer recalled that when she taught school at Maury, she lived in a little cabin across from the school, on the "old Glen Homestead." Evidently there was no suitable protection for her chickens so she kept them in the house. "I personally know from handling the shovel she roosted those chickens in the bathroom. I don't know how much lysol Mother and Dad used [to wash down the walls]. I could have slept in the barn a lot

${ }^{239}$ Pratt, Homesteader's Portfolio, 158-62.
Wilson interview. 
better!"241 This may be the same residence she described in Teacher's

Trek (p. 48-51). She wrote that the ranch house she was offered supposedly had adequate outbuilding for her animals. The chicken house which was to have been "made tight" was "delayed by matters far greater in the eyes of a stockman." The weather was extremely cold. She asked for, and received permission of, her landlord to house the chickens in the "lean-to of the ranch house." The next morning when she checked on her roosters, she found their wattles and feet frozen. She put them "'two by two' like Father Noah" into a crate and carried them into the kitchen so they could thaw out. As the roosters were unable to eat, probably due to frostbite, she kept them in the house for several days hand feeding them and rubbing Vaseline on their wattles.

The cows needed daily milking. Alice wrote in "Jerseys" that she handled one hundred cows, but Mary Wilson remembered it to be "about twelve. That's enough for one woman." 242 While they usually grazed on her property, she did move them to spring and fall feeding areas in the Maury Mountains. Usually this was a pleasant experience for her. She took time to marvel at the beautiful flora. She imagined what the first white man to see the area would have experienced. However, not all her memories were pleasant. She had calves born along the roadside, and walking a short stretch along the highway was a "nerve-racking experience." Some residents did not take kindly to her

${ }^{241}$ Don Brummer, interview with author, 22 July 1995, at the home of Don and Maxine Brummer, Prineville, Oregon. 
cows, just down from arid land, munching their lawn and gardens. "Goodnatured women have come with brooms and laughingly helped me through. Bad-natured men have descended from their lairs to the curb and venomously 'blessed me out.'"'243

\section{LAND OF ONE'S OWN}

The summer of 1916 truly was eventful. Not only had she planted and harvested her first crop totally by herself, she had accomplished what so many had failed to do: fulfilled the requisite residence and improvements. Her "proof was incontestable." By this time Alice was anxious to return East to spend some time with family and friends. In addition she acquired a teaching position. She made arrangements to leave her cows, horses, and chickens with neighboring farmers. While it may seem odd to leave one's home, crops, and animals for an extended or indefinite time, this was not uncommon practice among homesteaders.

The one damper to her joys was the death of her beloved Bingo, her companion for over ten years. His health had been declining, and only five days before she was to leave, he had a stroke resulting in partial paralysis. Although she carried him in and out for two days, he was in so much pain, she knew the only solution was to administer the morphine she had been saving for an emergency. Mary Wilson and her mother were invited "by special

\footnotetext{
${ }^{242}$ Wilson interview.

${ }^{243}$ Pratt, "Jerseys," 58.
} 
invitation" that day for lunch. She remembered seeing Bingo in his bed covered with a blanket. Wanting to play with the dog, she went over to the basket, only to be told by Alice to leave the dog alone because he was sick. Mary later learned that the dog was dead. Alice must not have been ready to bury her devoted companion. ${ }^{244}$

Satisfied with the arrangements for her homestead, and with "tears raining down" her face, Alice departed Broadview for two years. ${ }^{245}$

HIATUS

Alice's parents still were in Marion, McDowell County, North Carolina. She stayed with them for a year and during that time she taught in various mountain schools. Unaccustomed to these communities, she quickly learned about the mountain clan political power structure. Upon the installation of a new school superintendent who had no proclivity for education and school management, a minor "emergency" existed. "In such an emergency, it was the custom to seek some practical and tested teacher to look after the schoolroom methods and school management, while the superintendent handled those less definitely defined obligations for which he had been elected"246 Alice became the new school supervisor.

McDowell County is cotton growing country. Two schools, built and equipped by manufacturing companies and supervised by the county, existed

\footnotetext{
${ }^{244}$ Wilson interview.

${ }^{245}$ Pratt, Homesteader's Portfolio, 170-77.
} 
in outskirts of Marion. During her supervisory rounds, Alice observed quite a disparity in the quality between the schools near Marion and those "beyond the wagon road, well up the slopes of the Blue Ridge." 247 On a return visit to one of the mill district schools, she discovered, to her appalling amazement, a classroom, once filled with students, now almost empty. In defiance of North Carolina child labor laws, the children were missing school to work in the mill. "Having lived for several years in the far West, the supervisor was innocent of the fact that the child labor issue was a potato almost as hot as was the issue of slavery before the Civil War."248 True to Alice's sense of social justice and concern for children, she reported the issue to the school and the mill superintendents. However, as an outsider, she had little support. Alice was called into the school superintendent's office and severely reprimanded. The mill supervisor, also in attendance, "delivered a Hitler-like harangue and ultimatum." The state supervisor, "a politician of politicians," observed the schools and praised them. The end result: Alice completed the year but in July received a letter stating the county had decided "to employ a professional superintendent, and for reasons, of economy, dispense with a supervisor."249

In 1918, following the two year hiatus, Alice returned to Broadview and her beloved animals. Unfortunately, the Broadview to which she returned was not the one she left. Originally satisfied that her animals and property would be

\footnotetext{
${ }^{246}$ Pratt, Teacher's Trek, 15.

${ }^{247}$ Pratt, Teachers' Trek, 15.

${ }^{248}$ Pratt, Teacher's Trek, 17.
} 
well cared for, she returned to find her "neighbors' cattle fattened upon my growing crops and exploited my excellent pasture, ruining it for years to come." Her fences "were flat upon the ground and stock roamed at will throughout the place."250 Because farming and raising chickens and dairy cattle was not a lucrative profession, like other homesteaders, Alice was forced to find employment.

\section{FARMING DOES NOT PAY THE BILLS}

Homesteading itself did not provide sufficient income and, as before, she relied upon teaching. Shortly after her return, she applied for a teaching position in Baker, Oregon. A letter from A. C. Strange, superintendent of Baker public schools stated, "In reply to your letter of August $16^{\text {th }}$, will say that we have no vacancy in our corps of teachers at the present time."251

Alice did take several teaching positions throughout her eighteen years in Prineville and one door to door sales job selling ''The Cyclorama,' an outwardly intriguing condensation of all knowledge, with graphic illustrations." 252 Unfortunately this venture proved to be disastrous. She was required to purchase the book at the reduced price of twelve dollars and to take a "free" training course, though paying her own expenses while in

${ }^{249}$ Pratt, Teacher's Trek, 18. It is interesting to note her choice of words: "Hitler-like." Although she wrote the manuscript (probably) in 1960, this particular incident took place during the 1916-17 school year.

${ }^{250}$ Pratt, Homesteader's Portfolio, 179.

${ }^{251}$ A. C. Strange, Baker, Oregon, correspondence to Alice Day Pratt, 19 August 1919, Crook County Historical Society, Prineville, Oregon.

${ }^{252}$ Pratt, Teacher's Trek, 25. 
Portland, in which she was to learn appropriate salesmanship. The "appropriate" technique was to say that the Cyclorama was better than any other books on the market. As she had done in other situations, Alice protested what she believed to be untruthfulness on the part of the Cyclorama company. She went to Gill and Company to acquire text books in order to prove to her training teacher that other books were just as good as Cyclorama. She also abhorred the method of "encouraging" potential customers to buy the book. After a private interview with the firm during which she presented her position for presenting the book in her own way, she and Pax, her new one half spaniel dog, ventured out. For almost twenty-five days, she canvassed from Portland through the Willamette Valley, to Tillamook and Bay City on the coast, and back to Portland, all by foot. Her next assignment was east, over Mount Hood to her home in Post. In all, Alice and Pax walked fifty five days from Portland west to the coast and then homeward trying to sell the books. Her manuscript contains vivid descriptions of the private flower gardens, the natural vegetation of the Coast Range and Mount Hood, and the produce brought into Portland markets by truck gardeners. When she arrived in Prineville, she gladly accepted a job teaching school in the Conant Basin. ${ }^{253}$

${ }^{253}$ Pratt, Teacher's Trek, 30-38. Her manuscript is not clear about the date of this job although it probably was in the early to mid 1920s. It was during her second year teaching at Murphy Camp. She wrote that she came "in touch with the first wave of the fast-advancing Great Depression" (p. 27) and that "it was Prohibition time" (p.36). She does not say exactly where Murphy Camp is and it does not appear in Oregon Geographic Names. Lewis L. McArthur informed me that Murphy Camp, a logging camp named after a prominent lumberman, was located on Murphy Camp Creek, an unnamed stream running into the upper reaches of the East Fork Trask River, Tillamook County. 
For the next two years, probably in the mid 1920s, she lived in Conant Basin and taught at Conant Basin School, "twenty-five miles from town, ten miles from county store and post office, barred at times by a raging river on the one hand and impassable drifts on the other."254

Here she leased a house. On Saturdays she "baked, and brewed, and churned, and washed for the week to come" and on Sundays she made the twenty mile round trip to Broadview, "an almost all-day trip on a short winter's day. ${ }^{255}$ When she had eggs and cream to take to the Post store and stage, she would go by horse team and wagon. Usually, however, she rode Rab as Pax, the dog, busied himself chasing jack rabbits and sage rats. Even though she rode horseback, it was not a leisurely ride. "This regular trip meant negotiating thirty-seven gates, which, being barbed wire gates, demanded dismounting and remounting that number of times. The Basin teacher did not take her exercise to music but she took them!" Frequently she would have dinner with one of the local families where she enjoyed the companionship and the exchange of local news and "any world news arresting enough to have penetrated the sage brush country." 256

${ }^{254}$ Pratt, Teacher's Trek, 40. A sentence she included on this page is quite curious. While teaching at Conant Bason, she was quite pleased that "so soon after "World War I, the maps were up to date. Then she wrote, "Teaching within a stone's throw of Princeton University the following year, she [Alice] used pre-war maps throughout the year, despite constantly renewed requests." I have found no evidence so far that she went East for any length of time other than her hiatus between 1916-1918. This may again be another example of discrepancy in dates.

${ }^{255}$ Pratt, Teacher's Trek, 41. It's not totally clear from her writings if this is a second position in Conant Basin because in Homesteader's Portfolio she talks about making the twenty mile round trip on Sundays to Broadview.

${ }^{256}$ Pratt, Teacher's Trek, 42. 
Alice also taught school in the Oregon coastal community of Wheeler in 1927. In a letter to Mrs. John (Knox), she wrote, "I have my favorite age of children, -- the youngest - and find them very sweet and capable." At this time she was quite comfortable leaving her animals, with the exception of Scotty, the dog, and Little Kit, the cat, behind stating, "I am easy about everything at Post. No one has ever been so good to me about my critters as Mr. Groff is being, and it gives me some chance to make headway."257 Although it is unclear to whom she is writing, she may have spent part of the 1926 Christmas break in Portland. She wrote that she enjoyed the "glimpse into fruit and vegetable farming in The [Willamette?] Valley and that the coastal storms are "very different from YOUR drizzle." 258

In addition to teaching and the responsibilities of maintaining her homestead, Alice was writing. Two of the five articles published in Atlantic Monthly, "Feathered Affection" and "White Leghorns" appeared in June 1915 and July 1916, respectively. Two poems, "Song of the Homesteaders" and "Heritage" appeared in Sunset, August 1913 and March 1915, respectively. Subsequent to her 1918 return to Broadview, she wrote Homesteader's Portfolio. After submitting it to the publisher, she received a letter of encouragement.

We have been very charmed in our reading of it and believe you have here the material out of which to make an interesting

${ }^{257}$ Alice Day Pratt, Wheeler, Oregon, correspondence to Mrs. John, 27 February 1927, Crook County Historical Society, Prineville, Oregon.

${ }^{258}$ Alice Day Pratt, Wheeler, Oregon, correspondence to Girls (all three), 2 January, 1927, Crook County Historical Society, Prineville, Oregon. 
publication... In general our thought is this: That the book is a little diffuse and scattered in its appeal, that your story, the story of 'homesteading,' might be taken out from the matter which is only indirectly related to it and that this might well comprise the book... What we have in mind is that if the book could be made to take somewhat the form of Hamlin Garland's SON OF THE MIDDLE BORDER it would be of distinct advantage..$^{259}$

She did rework the book and in 1922 it was published. The promotional letter of The Macmillan Company's Library Department included the following

Breathlessly, right on the tip edge of your chair, you'll read Miss Pratt's account of the incubation of her first chicks. Will there be any survivors from the alternate chilling and roasting?

From the first chapter which gives an excellent picture of the journey West to the last - dealing with accomplishment eleven years later, the narrative is intensely interesting. Regardless of the frank recital of the many hardships and difficulties encountered, you'll feel like starting on a like venture.

But you cannot down a woman who cuts her crop with carving knife! The reader cannot but thrill to the straightforward, spirited narrative. As you reluctantly close the last page, you feel with the author that 'wilderness and the solitary place have been glad, and Nature has not betrayed the heart that loved her.,260

\section{LONELINESS?}

Alice's books do not suggest she lacked for companionship, yet in a letter dated 8 December 1950, she wrote to a friend in Prineville, "It isn't good to be all together alone -- and i (sic) speak from experience." 261 Her constant

${ }^{259}$ H. S. Latham, The Macmillan Company, New York, NY, correspondence to Alice Day Pratt, 9 October 1920, Crook County Historical Society, Prineville, Oregon. In "Jerseys" (p. 55), Alice took issue with Garland's writing where it refers to calves and farming. She wrote, "Garland was no born farmer. He lacked the tastes and appreciations (sic) that are the alleviations (sic) of the hardships of farming."

${ }^{260}$ The Macmillan Company Library Department, New York, NY, correspondence to Alice Day Pratt, December 1922, Crook County Historical Society, Prineville, Oregon.

${ }^{261}$ Alice Day Pratt, New York, NY, correspondence to Lily, 8 December 1950. Crook County Historical Society, Prineville, Oregon. The person she is writing to probably is Lily 
companions were her animals, her dogs Bingo and Pax, the cats, Kitty Kat and El Dorado, her horses, her cows and her chickens. The dogs traveled everywhere with her. When she left Broadview for various teaching jobs to support herself, they went too. Ranching and her animals provided relief from the monotony of teaching. She wrote

I had for house companions Pax, the dearest of dogs, several attractive cats and kittens. My flock of White Leghorns were in good production. Their cheerily vocal presence about house and barn, their winged rush to greet me when I came I home from school, as well as the piles of snow white eggs that accumulated for market, gave me great pleasure... There are traits of personality in all species that are seldom recognized and appreciated by the human in his preoccupation with his own kind. ${ }^{262}$

Residents of Prineville who knew her, all mention her dog(s) how she seemed never to be without one. Those who had her for a teacher tell a story about Bingo being allowed to drink out of the same water bucket used by the students, a practice which they believed to be disgusting. ${ }^{263}$ According to her nephew Walden, " family tradition has it that Alice thought that if anyone should have been worried about contamination, it should be the dog, not the students!"264

Like most people far from family, she looked forward to receiving mail. "The infrequent mail was the great pleasure of my lone life, when, once more

Knox. Alice was good friends with the "Knox girls," Lilly and Vicie (LeVica). Vicie's homestead was due west of Broadview.

${ }^{262}$ Pratt, Teacher's Trek, 41.

${ }^{263}$ Interview with Beverly Wolverton, Flora Gilmore, Maxine and Don Brummer, and Frances Bushnell, 22 July 1995, at the home of Don and Maxine Brummer, Prineville, Oregon. Alice seemed to think the children tremendously exaggerated this incident and indicated there was no foundation for the alleged act, Portfolio, 95. 
at home and chores all done, I lit the evening lamp and renewed touch with old friends and with the outside world."265

She developed close friendships with Lily Knox, Vicie Knox, and Grace Knox, wife of John Knox whose homestead was in the Conant Basin. Another good friend was her neighbor Mary Demaris, Mary Demaris Wilson's mother. Mary recalled that Alice sewed a christening dress for her. She said that when Alice's mother and sister came to visit, they spent time with Mary and her mother. $^{266}$

Despite these friendships, Alice didn't seem to "fit in" with the community. Her books Homesteader's Portfolio and Three Frontiers contain descriptions of conflicts with neighbors, most notably the "Old Oregonian" and the "Wild Man from Borneo." Writing to Mrs. John, in 1932, she expressed her concern about her horses. Someone left the gates open and they got loose. She recalled an earlier incident, "It recalls to mind the season when I first got my 640 enclosed, I had to leave just before the fence was complete. The fence maker wrote me that it was done, and collected his pay. I was told that he made a good gate and fastened it open before he left, in deference to his neighbors."(italics mine $)^{267}$ In Teacher's Trek, she revealed her dislike of John Beoletto who she refers to as a "perennial problem." 268 Over twenty years later, she recalled

${ }^{264}$ Walden Pratt, correspondence to author, 28 April 1998

${ }^{265}$ Pratt, Teacher's Trek, 42.

${ }^{266}$ Wilson interview.

${ }^{267}$ Alice Day Pratt, Niagara Falls, NY, correspondence to Mrs. John, 20 May 1932, Crook County Historical Society, Prineville, Oregon.

${ }^{268}$ Pratt, Teacher's Trek, 39. 
Beoletto, "Didn't we have our 'incidents' with the old man?"269 Some of the locals ridiculed her, particularly the school children. She was a tall, thin woman and some called her "Scarecrow." 270

Besides being a woman homesteader whose views on animals differed quite drastically from prevailing norms, Alice was well educated, outspoken, and an outsider from the East, qualities which did not endear her to some neighbors. Cora Houston stated that Alice didn't get along well with her neighbors 'because she was 'different,' being from the East and doing things in a more formal way,"271 Mary Demaris Wilson's theory is that locals decided Alice thought she was better than they. She thinks this treatment really hurt Alice and, as a result, she did not socialize much. ${ }^{272}$ Neither Flora Gillmor, Don Brummer, or Mary Wilson remember Alice attending many community activities. Brummer stated, "She didn't get out and about a lot." ${ }^{\text {"73 }}$ Alice must have attended some social activities because Clarine Silver did find tattered remnants of a cranberry-colored silk dress and a kid leather glove. ${ }^{274} \mathrm{~A}$ photo in the Crook County Historical Society museum depicts Alice with several other community members at what Wilson believed to be a Thanksgiving dinner at the grange. One can only make guesses as to how many activities she attended and her reasons for not becoming more involved.

\footnotetext{
${ }^{269}$ Alice Day Pratt, New York, NY, correspondence to Grace, 28 April 1953. Crook county Historical Society, Prineville, Oregon.

${ }^{270}$ Brummer interview.

${ }^{271}$ Houston correspondence to author.

${ }^{272}$ Alice made Wilson's baptismal dress, probably a side of her few people knew. Wilson interview.

${ }^{273}$ Gillmore and Brummer interview, 22 July 1995. Wilson interview.
} 


\section{GOODBYE TO BROADVIEW}

During the Great Depression, twenty-five percent of American farmers lost their farms. Alice was one of them. Sadly in 1929, despite teaching jobs and her dairy and egg business, Alice found herself financially unable to continue farming. In 1925 Mattie Elliot filed a lien against her in the amount of " $\$ 800.00$ with the interest thereon at the rate of 10 per cent per annum from the $4^{\text {th }}$ day of August, $1924 \ldots$ together with the sum of $\$ 60.00$ as a reasonable sum to be allowed by the Court as attorney fees in this suit." Between October 1922 and October 1924, Alice made payments totaling two hundred sixteen dollars but due to lack of funds she fell behind. ${ }^{275}$ In 1929 she was forced take out a loan on her Jerseys. "To keep my Jerseys, I have taught during parts of most years, earning the disrespect of my business-minded friends, the disgust of banks and loan companies that have from time to time seen me through the dubious experiment, and, for myself, gray hairs, calloused hands, and - some intangibles."276 The following fall the price of butter dropped to "'ten cents a pound and eggs to twenty cents." She was unable to pay off the loan and in the spring of 1930 a loan company took possession of her beloved cows. ${ }^{277}$ In a letter to her mother, Alice wrote, "Laddie and the heifers went for beef, which is not so bad from a business standpoint as it might seem, since a great deal

\footnotetext{
274 Silver, "Old Maid."

${ }^{275}$ Central Oregonian, Prineville, 10 February 1925. I have been unable to find out the details of this lien or who Mattie Elliot is.

${ }^{276}$ Pratt, "Jerseys," 52.
} 
of good dairy stock is going that way. It's all cruel and horrible to me at the best. I simply have to take it as one of the horrors of the world 'the way it is."'278 Mary Demaris Wilson recalled walking with Alice the day she drove her cattle into town. ${ }^{279}$ Alice's love of her animals and her farm must have made this trip extremely difficult.

She gave away her chickens to neighbors and she left her beloved horses with neighbors, John and Grace Knox. Alice maintained a vigilance of her horses via mail. In a letter dated 2 March 1933 she expressed pleasure that the Knoxes would keep an eye on them so that they "don't suffer at any season." In another letter to Grace dated 9 July 1933, she asked about the horses and wondered if they were "all running together." Still another letter, dated 13 September 1933, she expressed concern about the horses not finding enough to eat in the snowy weather. She asked Grace to please give the horses some hay and promised she would send some money for a ton of hay and, if necessary, additional money. Her horses were an integral part of a lifestyle she dearly missed. Her anguish was poignantly expressed in "Hippos:"

I pray that no evil fate may intervene, but that, in memory of our age-long but unworthy friendship with this high-minded creature, Fly and her little company may live out their lives upon this solitary butte, haunting the south side in the winter season and the north side in summer, tasting the wine of spring in the first green blades and the strength of maturity in the ripened seed, hiding beneath

${ }^{277}$ Pratt, Frontiers, 132 and Brooks Ragen, "Alice Day Pratt in Oregon," copy of unpublished manuscript, original is in possession of Brooks Ragen, 31.

${ }^{278}$ Ragen, 31.

${ }^{279}$ Wilson interview. 
juniper canopies from driving storms, and seeking the first rays of morning on the pinnacle of the hill, gleaming like Pegasus on the top of Helicon. ${ }^{280}$

Although fiercely independent, in the face of financial ruin, one might wonder if Alice ever appealed to her family for financial help. Her nephew Walden believes "Alice would have been too proud to ask [for aid] unless she were literally starving."281 Brooks Ragen, who corresponded for several months with Alice's brother Julius, cited the following response

You, and others, may reasonably have wondered why Alice, in her struggle to make a success out of her ranch, never received substantial aid from her family. The fact was that no one in her family was in a position to give much help. My father was in his 70's when Alice began her venture, and his business had languished to such an extent that I from my first job after finishing college, had to supplement his income. After I was married in 1919 , my parents spent several months of each year with me and my wife, and I soon had a growing family of my own. Alice was aware of all this and knew, when she embarked on her adventure, that she would be on her own. I did help her a little from time to time, with loans or endorsement of notes, but there was not much that $I$, or others of the family could do. What finally destroyed her brave attempt to make a success of dairy and chicken farming was of course the onset of the depression of the 1930'[s]"282

Dejected, but not without hope, Alice left Broadview. Though she hoped to return one day she never did. Her feelings were expressed in the closing words of Three Frontiers. "At this point - at the close of nineteen-thirty - not

${ }^{280}$ Pratt, "Hippos," 743.

${ }^{281}$ Walden Pratt, correspondence to author 31 October 1996.

282 Ragen, 32. Bank records of her checking account dated 21 September 1929 show she had $\$ 2.63$ followed by another entry of $\$ .03$. Moneys were added but by 24 December 1929 her account was down to $\$ .17$. The last deposit, in the amount of one hundred dollars was made on 24 December 1929. On 12 April 1930 her balance is $\$ .17$ and on 29 April 1930 
only penniless but in debt, I bade goodbye to the slopes of Broadview, which I had so dearly loved for eighteen years, and accepted a niche in which I could be useful in the affairs of my family in the East."283

there was no money in the account. The Prineville National Bank, Crook County Historical Society, Prineville, Oregon.

${ }^{283}$ Pratt, Three Frontiers, 132. 


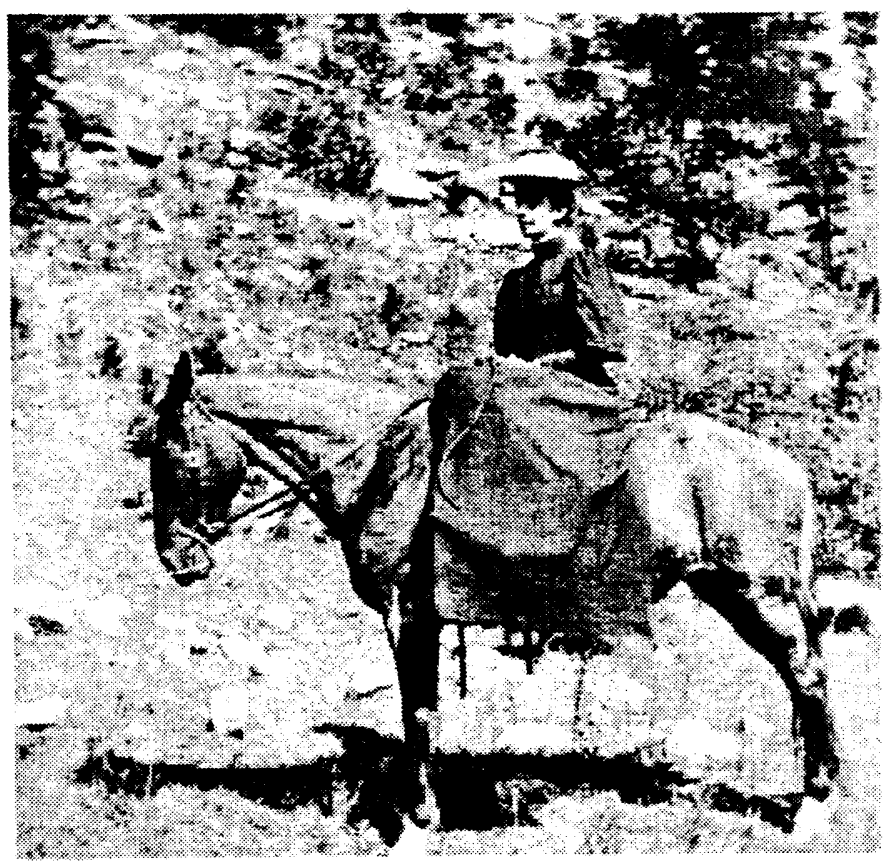

Alice on her horse, Fly

Courtesy of Crook County Historical Society 
Fublalles $09722^{2}$ mo15833

\title{
The United States of America,
}

TO ALL TO WHOM THESE PRESENTS SHALL COME, GKEETING:

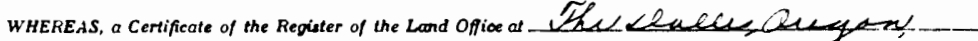
has been deposited in the General Land Office, whereby it appears that, purnuant to the Act of Congred of May 20,1862 "To Secure Homesteads to Actual Settkrs on the Public Domacin," and the acts supplemental thereto, the claim of Hueselay (xatt

has been established and duly consummated, in cortormity tolaw, for the

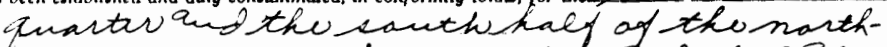
mest anatew of section thew hod the at

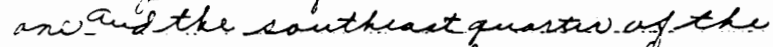
mantheret quatew af hection fow in Tomn-

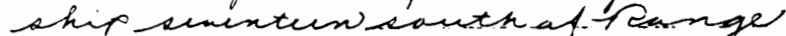

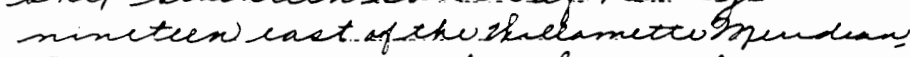

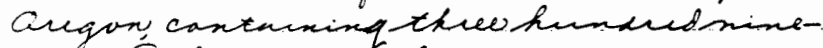

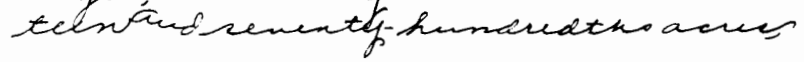

according to the Oficial Plat of the Survey of the aaid Land, retumed to the General Land Office by the SurveyorGeneral:

NOW K.NOW YE. That there is, thesefore, granted by the CNITED STATES unto the said claimant__ the tract of Land above described; TO HAVE AND TO HOLD the said tract of Land, with the appurtenances thereol. unto the said clainant___and to the heirs and assigns of the said claimant___ frever; subject to any vested and accrued wuter rights for mining, ngricultural, manufocturing, or other purposes, and rights to ditches and reservoirs used in connection with such water rights, as may be recognized and acknowledged by the local customs, laws, and decisions of courts; and there is reserved from the lands hereby granted, a right of way thereon for ditches or canals constructed by the authority of the United States.

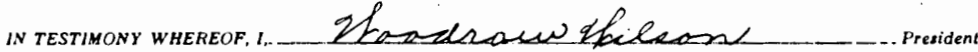
of the linited States of American, have caused these Letters to be made Patent, and the Seal of the General Land Office to be hereunto al/ixed.

Given under my hand, at the City of Washington, the doy of Acsenat. in the year of our Lond one thousand nine hundred and Als ateens.... and of the independence of the \{EmERaL LANO United States the one hundred and futed: fiset

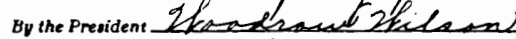

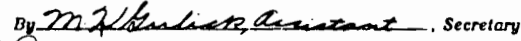

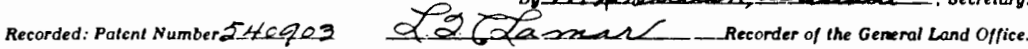

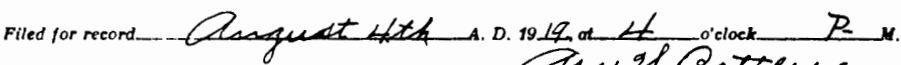

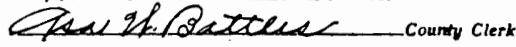

By

Deputy.

\author{
Alice's patent \\ Courtesy of Crook County Courthouse
}




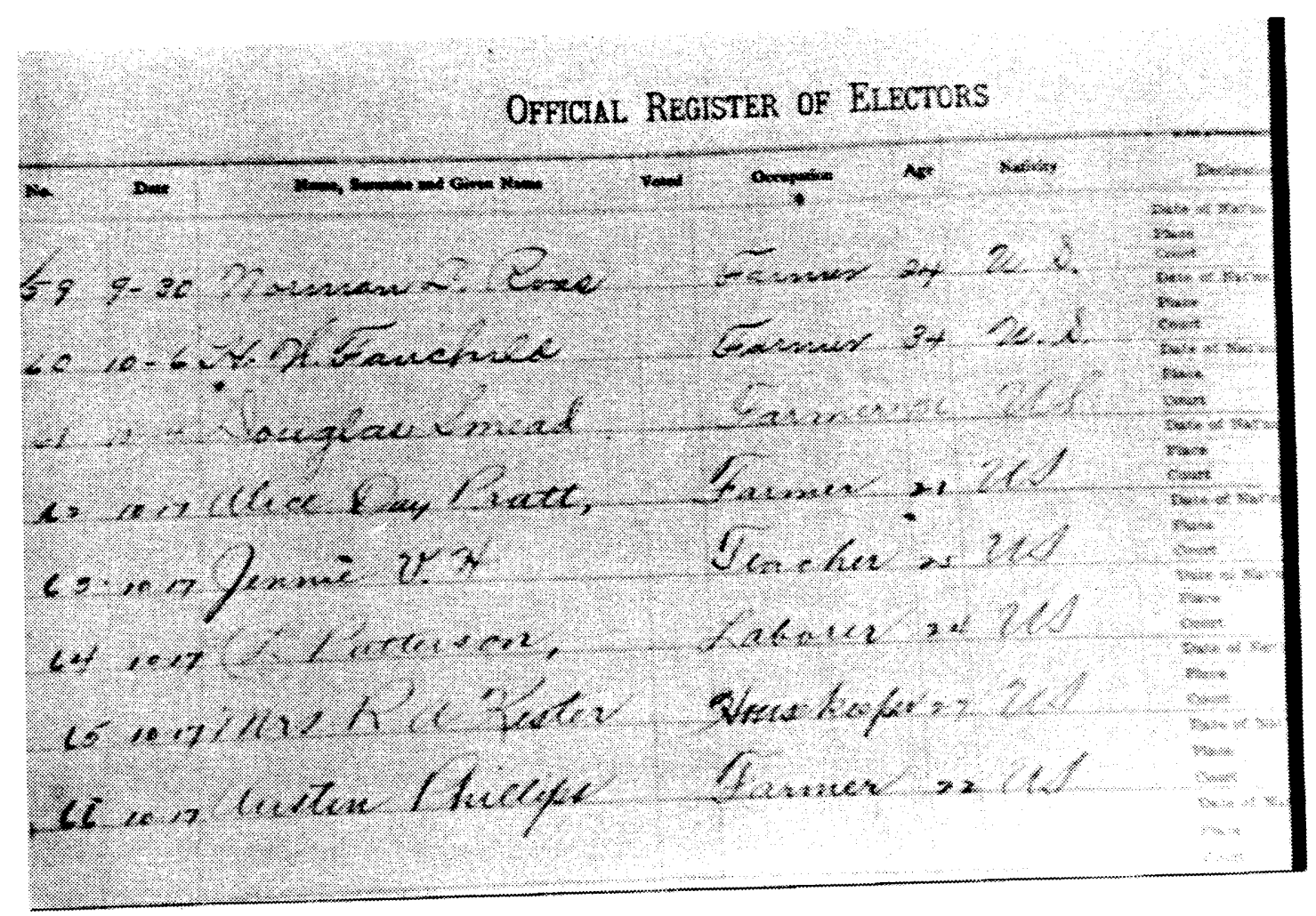

1912 Voter's Registration

Courtesy of Crook County Courthouse

Nowhere in her writings or in her letters does Alice mention voting but this page from the 1912 Register of Electors shows she did register to vote.

Knowing her interest in political affairs and social justice, one would expect her to vote. Note that her age is listed as twenty-one, not thirty-nine. 
Chapter 6

\section{LIFE AFTER BROADVIEW}

Truth does not depart from human nature. If what is regarded as truth departs from human nature, it may not be regarded as truth

Confucius

Age brings a philosophy of its own and it seems all right that activity should become a memory. Especially if one had taken a big share of activity there is more or less a sense of satisfaction. ${ }^{284}$

Penniless, Alice returned East, this time to upstate New York where her family was living. Julius was teaching history at The University of Buffalo, a private school which later became State University of New York at Buffalo (SUNYAB). Marjorie was teaching elementary school in Niagara Falls. William and Sophie had been living with Julius and his wife in Buffalo until William's death in 1928, after which Sophie moved in with Marjorie.

Alice lived in Niagara Falls and Old Forge, teaching school, until about 1936 when she, Marjorie, and their mother moved to New York City. While in upstate New York, she spent a considerable amount of time with her brother and his family. Walden recalled visiting her "once a month or so." Both of her nephews "were quite devoted" to their aunts, "and they to us." Her letters to her nephew illustrate her love for both William and Walden as well as their children. She seemed to delight in being with the children and frequently mentioned looking forward to their visits. In a letter written in 1950, she

${ }^{284}$ Alice Day Pratt, New York, NY, correspondence to Lily, 1 December 1955, Crook County Historical Society, Prineville, Oregon. 
offered to go to William's house to babysit their child, her great nephew, for a weekend. ${ }^{285}$

She enjoyed camping in the Adirondacks and at times her nephews would accompany her. She converted a bread delivery truck into living quarters setting it up on blocks in a clearing near the edge of the woods. In a letter to William Alice wrote of the comforts of this home

Moving in your house is funny but very convenient in some ways a little like the covered wagon... It is the most convenient sort of camping I have tried. A trailer with springs - so that it would travel comfortable - would be perfectly ideal for summer, I think. One could linger just where one chose and go on whenever one wanted to change neighbors. ${ }^{286}$

Of one camping trip, Walden stated,

I remember spending a very happy month with them [his aunts and grandmother] at Old Forge in the Adirondacks one summer in the late 30 s... We would spend most of the day playing card games or reading or walking the $1 \frac{1 / 2}{2}$ miles to town, or sometimes taking a picnic lunch on a hike in the woods, and every evening they would take turns reading aloud from books that appealed to all of us. ${ }^{287}$

He fondly recalled Alice's concern about his small size and lack of athleticism.

She carefully kept a daily record of his food consumption and if he did well, she rewarded him with "a chunk of a big Hershey bar." ${ }^{288}$ Another summer, William joined her for a few weeks on a lake in Ontario where Alice spent the summer camping.

${ }^{285}$ Alice Day Pratt, New York, NY, correspondence to Children, 16 December 1950 , photocopy, original is in the possession of William Pratt, State College, PA.

${ }^{286}$ Alice Day Pratt, Old Forge, NY, correspondence to Billy Winston, 28 June 1936, photocopy, original is in possession of William Pratt.

${ }^{287}$ Walden Pratt, correspondence to author, 31 October 1996. 
As it was the time of the Great Depression, she did encounter difficulty finding employment. In a 1933 letter, she wrote, "I find, of course more and more interests and occupations here - nothing remunerative yet ..."289 Although she probably is referring to teaching, she did have some writings published. Her articles, "Jerseys" and "Hippos," appeared in 1931 editions of The Atlantic Monthly. Another, "I Take to the Woods," was published in the same magazine in 1932. The later article is a descriptive celebration of the natural landscape of three mountainous areas: Black Mountain and Blue Ridge in the Appalachians, the Black Hills of South Dakota, and Neahkahnie Mountain in the Coast Range of Oregon. Her second published book, Animals of a Sagebrush Ranch, (1931), is a children's book about a little girl named Peggy who went by train to a new home, Broadview, in "a new, sunshiny country, where Uncle Sam had homesteads to give to his children." Alice fictionalized events during her eighteen years at Broadview including Bingo's death, the birth of Pax on Armistice Day, the arrival of horses Fly and Rab, and sleeping under a log in the rainy Coast Range with Pax. The stories in this book illustrate the devoted relationship Peggy (Alice) had with her animals and their unselfish loyalty to her. An overarching theme was the moral lesson about the value of all animal life.

Alice wrote two novels but they were not published. The Ochoco Project, is a semi-ficticious account of the large irrigation project in the Ochoco

${ }^{288}$ Walden Pratt, correspondence to author, 31 October 1996. 
Mountains near Prineville. ${ }^{290}$ Another unpublished manuscript was

Sagebrush Fires, a novel in two parts, about Barbara Wescott, a young girl, who, with her parents, become homesteaders in Prineville. Again, this novel is very descriptive of Alice and her experiences. Barbara is a vegetarian and not anxious to marry, preferring to complete her education and maintain her independence. The cattlemen of the area are prejudiced against the sheep ranching, educated Westcotts. Like Animals of a Sagebrush Ranch and Animal Babies, published in 1949, this novel contained a strong moral message. Alice submitted Sagebrush Fires to The Atlantic Monthly, and even after she made revisions, the editors did not accept it. Encouraging her to make further revisions and noting several areas which he believed to have significant problems, Edward Weeks wrote,

Dr. Wescott's moralizing can well be spared. A sermon of this kind is better indicated by actions than by being preached direct from the author to the reader... In Section 2 of your story, a sentimental note begins to make itself manifest every now and then. Generally speaking your narrative is much too firm to admit such soft spots...Finally, Chapter XII seems to me altogether too lame a conclusion. I don't ask for a Hollywood finish, but I do think that you might bring the lovers together with some episode of greater spirit, -- one which will give a fillip to the whole narrative. ${ }^{291}$

${ }^{289}$ Alice Day Pratt, Niagara Falls, NY, correspondence to Friend, 25 September 1833 , Crook County Historical Society, Prineville, Oregon.

${ }^{290}$ Ragen, 39.

291 Edward Weeks, Boston, Massachusetts, correspondence to Alice Day Pratt, 31 December 1931, photocopy of manuscript and editor's letter, original is in possession of Walden Pratt, Arvada, Colorado. I do not know if this manuscript, the copy of which I possess, is the one Mr. Weeks is referring to or if it is a later revised edition. The reason is that Weeks' letter is dated 1931 and Alice's address on my copy is $535 \mathrm{~W} 112^{\text {th }}$ St., NY 25, NY, an address which I do not find in correspondence with family and friends prior to 1949. Additionally, her nephew Walden said that she moved to New York City in 1936. 
She may or may not have continued to revise this manuscript.

Alice did miss Broadview. Letters to friends often contained references to her animals and her desire to return. In 1933 she wrote, "How I should love to spend a little time getting them [the horses] to know me again. It always gives me heartache to think of the life there. I loved it so but there were so many bad happenings. I still hope to come back, perhaps next summer, for a time anyway." families and doings." ${ }^{293}$ A year later, she again wrote, "I can just imagine how busy you all are with haying and garden and stock. It all appeals to me more strongly than any other life. I never get over missing it."294

In 1937, the year she turned sixty-five, Alice and Marjorie moved to New York City where she lived until her death in January 1963. She does not give a reason for this move. Her nephew thinks it may have "had something to do with her retirement." ${ }^{295}$ During this time she continued to write; however, only Three Frontiers and Animal Babies were published. Other manuscripts include The Marginal Life, an autobiographical narrative of her life, The Book of Chronicles of Wight (ess), a semi-fictious account of life near Friar's Butte,

${ }^{292}$ Alice Day Pratt, Niagara Falls, correspondence to Friend, 25 September 1993, Crook County Historical Society, Prineville, Oregon. It is not known what employment she had prior to teaching in the New Deal preschool in 1934.

${ }^{293}$ Alice Day Pratt, Niagara Falls, correspondence to Mrs. John, 21 July 1935, Crook County Historical Society, Prineville, Oregon.

${ }_{294}$ Alice Day Pratt, Old Forge, NY, correspondence to Friend, 9 August 1936, Crook County Historical Society, Prineville, Oregon.

${ }_{295}$ Walden Pratt, correspondence to author, 31 October, 1996. 
and Depression on the Rimrock, a short story of life in Central Oregon during the Depression. ${ }^{296}$

Throughout her life, Alice maintained an active interest in current affairs. Her writings about her homesteading era reveal little about any political activities other than her "run ins" with school boards. If there were political and/or social action groups in Prineville, she may not have had time to participate in them. Her signature does appear on the 1912 election roster, the same year women gained the right to vote in Oregon. Alice's liberal ideology is quite evident in letters to family following her move to New York City where she listened to radio programs and attended meetings and discussion groups. In a letter dated January 1939, she wrote

Do you ever listen to the Town Meeting on the Air? I enjoy it. It ventilates a good many immediate questions and gives both sides, of course... Last Sunday night I heard Mr. Walsh, who was or became - person non grata at Harvard because of his proletarian interests. He was one of the finest and most convincing speakers I have heard. Martin Dies quite the opposite. I hope they will get rid of him and still employ a committee that will take and (sic) interest in Nazis as well as Communists. ${ }^{297}$

She was a friend and an ardent admirer of liberal clergyman, author, pacifist, and civil liberties activist, John Haynes Holmes. ${ }^{298}$ She attended

${ }^{296}$ Ragen, 39.

297 Alice Day Pratt, New York, NY, correspondence to Billy, 27 January 1939, photocopy, original is in possession of William Pratt, State College, PA.

298 John Haynes Holmes, a Unitarian clergyman, spoke out against America's involvement in World War I. He worked with John Dewey and Charles Clayton Morrison for the passage of the Kellog-Briand Pact (Pact of Paris) which outlawed war. He was one of the organizers of the American Civil Liberties Union as well as the National Association for the Advancement of Colored People. He was a member of the Scottsboro Defense Committee which organized following the conviction of nine young Black men (falsely) accused of raping two white girls. Although he had at times allied himself with Socialists during the 1930s, on 2 
frequent lectures by him and may have been a member of his congregation at the Church of the Messiah (later Community Church of New York). ${ }^{299}$ After Alice's death, Dr. Holmes wrote a letter to Marjorie which included the following:

The news of the death of your sister saddened me deeply, though her great age and feebleness gave due warning. I shall count her friendship in fact and in memory as one of the most precious possessions of my life. Her last message lifts the heart and shall be counted, as long as I live, a part of my treasure-chest. ${ }^{300}$

She joined the Social Action committee, "which is a link between the church and the various social movements undertaken by the Government and by workers and underprivileged people." The group held Sunday afternoon discussion sessions "where every sort of person and every view is welcome. Here they had "well informed" speakers, "everything from Fascist to Communist." Following the discussion, she would attend the Forum lecture "where we have some of the most famous people from all over the world to give us first-hand information." A one hundred year old institution, the Forum

January 1940, he admitted he had been "'deceived, deluded, and disgraced - sold out by those I trusted most," in a sermon entitled "Why We Liberals Went Wrong on the Russian Revolution" See Marty Martin, Modern American Religion: The Irony of It All, 1893-1919, vol. I (Chicago: The University of Chicago Press, 1986), 276-278; Marty Martin, Modern American Religion: The Noise of Conflict, 1919-1941, vol. II (Chicago: The University of Chicago Press, 1991), 226, 232, 285, 287, 302, 360,; Charles H. Lippy and Peter W. Williams, eds., Encyclopedia of the American Religious Experience: Studies of Traditions and Movements, vol.I

(New York: Charles Scribner's Sons, 1988), 589-90.

${ }^{299}$ Walden Pratt confirmed that she was a member of a branch of the Community Church "in the neighborhood of $536 \mathrm{~W} 112 \mathrm{St}$.," in which he believes there is a pew or seat dedicated to her memory. Walden Pratt, correspondence to author 4 August 1997.

${ }^{300}$ John Haynes Holmes, New York, NY, correspondence to Marjorie Pratt, 17 January 1963, photocopy, original is in the possession of Walden Pratt, Arvada Colorado. The message Holmes referred to may have been one of several brief notes Alice wrote to her 
had no difficulty engaging speakers ranging from Mahatma Gandhi to Father Coughlin to Lin Yutang of China. ${ }^{301}$ She seemed to like Lin Yutang's ideology, stating, "I think no one had given me the sense of a world mind to the degree that Lin Yutang has done." ${ }^{302}$ Regarding her liberal proclivities, Alice wrote in a letter to her nephew, "I have warned some of my friends that I may yet be up before the Dies Committee." ${ }^{303}$

Although a pacifist, she definitely wanted to see Hitler defeated and seemed to became frustrated with Allied endeavors during World War II. To William she wrote,

Do you get to wishing to take a hand when you see Hitler forging ahead - the "raging heathen" such as the Bible tells about? "Arise, oh Lord, and let thine enemies be scattered!' I am anxious to see that offensive that we are supposed to be about to engage in. It does make one wonder why we have waited so long - meaning England. We know we aren't ready." ${ }^{304}$

family and friends approximately one year before her death. These notes were to be given to the individuals after her death. Walden Pratt, correspondence to author, 27 February 1998.

${ }^{301}$ Alice Day Pratt, New York, NY, correspondence to Billy, 7 November 1939, photocopy, original is in the possession of William Pratt, State College, PA.

302 Alice Day Pratt, Old Forge, NY, correspondence to Billy, 3 August 1941, photocopy, original is in the possession of William Pratt, State College, PA. Lin Yutang (1895-1976) was a Chinese intellectual. He earned an MA from Harvard and a Ph.D. from Leipzig. He was one of a group of intellectuals during the 1930s who were involved in a movement of discovery of their own country after a period of trying to imitate the West. See Lin Yutang, My Country and My People (NY: Halcyon House, 1938, original 1835 by The John Day Company, Inc.) and Hu Shih and Lin YuTang, China's Own Critics: A Selection of Essays (NY: Paragon Book Reprint Corp., 1969) with commentaries by Wang Ching-Wei.

${ }^{303}$ Alice Day Pratt, New York, NY, correspondence to Billy, 7 November 1939, photocopy, original is in the possession of William Pratt. The Dies Committee was the precursor to the later House Un-American Activities Committee. Walden stated that during the 1950s he was interested in joining the ACLU. When he told his aunt about it, she was quite interested, which "certainly would have been in keeping with her open-mindedness then..." Walden Pratt, correspondence to author, 4 August 1997.

${ }^{304}$ Alice Day Pratt, New York, NY, correspondence to Billy, 26 May 1942, photocopy, original is in the possession of William Pratt, State College, PA. 
Six weeks later, she again stated her frustrations, "I think there would be more inspiration in the present situation for all of us if we knew that we are contributing an ounce of power to the Allied endeavor. For all that we can see we are acting just like England and France before it all began."305 During the war she joined the War Manpower army and was "engaged in the construction of shoe arches, " a non-demanding job that "pays expenses."

Alice certainly continued to have an interesting life. She and Marjorie "run around together a good deal." They attended cultural events in New York such as the museums, went to movies, visited friends, and took care of their elderly mother. As always, her dogs and cats were constant companions. While on her homestead, someone poisoned Pax. Her next dog, Max, lived with her until his death in October 1942. He was followed by Tony, but, after his death, she decided not to have any more pets. "Marjorie brought me some gold fish a few days ago, in pity, I guess, for my bereaved state, Since my last dog and cat passed on I have not had a pet. I don't want to have them to leave and I can't expect to outlive them now. I do miss them."307

Not only was Alice now without a pet, but her New York living quarters were an "extreme contrast" to "the wide open spaces of her youth, middle age, and even later years in the Adirondacks." She and Marjorie each had a room "a few doors apart" from each other in a "rather run-down 'apartment house' in

${ }^{305}$ Alice Day Pratt, Old Forge, NY, correspondence to Billy, 18 July 1942, photocopy, original is in the possession of William Pratt, State College, PA.

${ }^{306}$ Alice Day Pratt, New York, NY, correspondence to Billy, 10 June 1945, photocopy, original is in the possession of William Pratt. 
which they "shared a small kitchen with several other tenants." According to her nephew Walden, Alice's room was no larger than eight feet by twelve feet of which one corner "was given over to a small toilet room." Her furniture "consisted of a twin-size 'day bed,' a small chest of drawers, a couple of chairs, and a desk by the window." The most striking contrast was the view. Where she once had a broad view of range land, mountains, and the sky, she now had only "a small window opening on an air shaft" where she and Marjorie "could see daylight but not the sky, unless they bent over to look straight up." ${ }^{308}$

Physical activity had always been a part of Alice's life, from horseback riding in the Black Hills, to the arduous work of creating a farm in sage brush country, to camping after her retirement. Unfortunately, by 1950 , incapacitated by arthritis in her hips and knees, her world closed in. "I am house-bound now, not being able to walk on the street (arthritis in hips and knees) but can go out now and then in czr (sic) or taxi. In the flat I can get to the kitchen and bathroom and take care of myself. Books, letters and radio are my staff of life."309 Her eyesight began failing also. In 1953 she was delighted by a surprise visit from her brother, nephews, great nephew and new great niece. Playing with "little Billy," she was saddened by the fact that she was unable to go outside with him. "I wanted to just as always but my knees! The little boy

${ }^{307}$ Alice Day Pratt, New York, NY, correspondence to Lily, 20 May 1950, Crook County Historical Society, Prineville, Oregon.

${ }^{308}$ Walden Pratt, correspondence to author, 28 April 1998.

${ }^{309}$ Alice Day Pratt, New York, NY, correspondence to Lily, 20 May 1952, Crook County Historical Society, Prineville, Oregon. 
was puzzled. I can get around my room in a sort-of-all-fours manner and do most personal things for myself. This machine [typewriter?] means a lot to me, also radio and reading. I cannot read very much however." ${ }^{310}$ By the beginning of 1961, at age eighty-eight, she was confined to the couch and, although she still corresponded with friends, she could hardly see the letters on the typewriter and was unable to read. "I do all my living on my couch. Am really getting used to it. It is a peaceful life. No chance for collisions - or not much. If my eyes had held out how much good reading I could have done."311 Marjorie continued to care for her sister, reading to her and discussing current affairs. In addition, during the last ten year of her life, Alice had been in involved in a reading circle which included a Mr. Beckett. He came regularly to read to her and discuss current affairs. ${ }^{312}$

. Although it must have been difficult for such an independent person, who makes no mention of illness, to become physically dependent on others, her letters indicate she did not lament her failing health. Her nephew Walden, stated that he never heard "her voice a word of complaint... about any other misfortune over which she had no control."313 Despite her physical limitations, her active mind remained lucid until she suffered a stroke from which she died three days later, at the age of ninety, on 11 January 1963.

${ }^{310}$ Alice Day Pratt, New York, NY, correspondence to Lil, 11 September 1953, Crook County Historical Society, Prineville, Oregon.

${ }^{311}$ Alice Day Pratt, New York, NY, correspondence to Grace, 2 January, 1961, Crook County Historical Society, Prineville, Oregon.

${ }^{312}$ John Haynes Holmes, New York, NY, correspondence to Marjorie, 17 January 1961, photocopy, original is in the possession of Walden Pratt, and Walden Pratt, correspondence to author, 31 October 1996. 


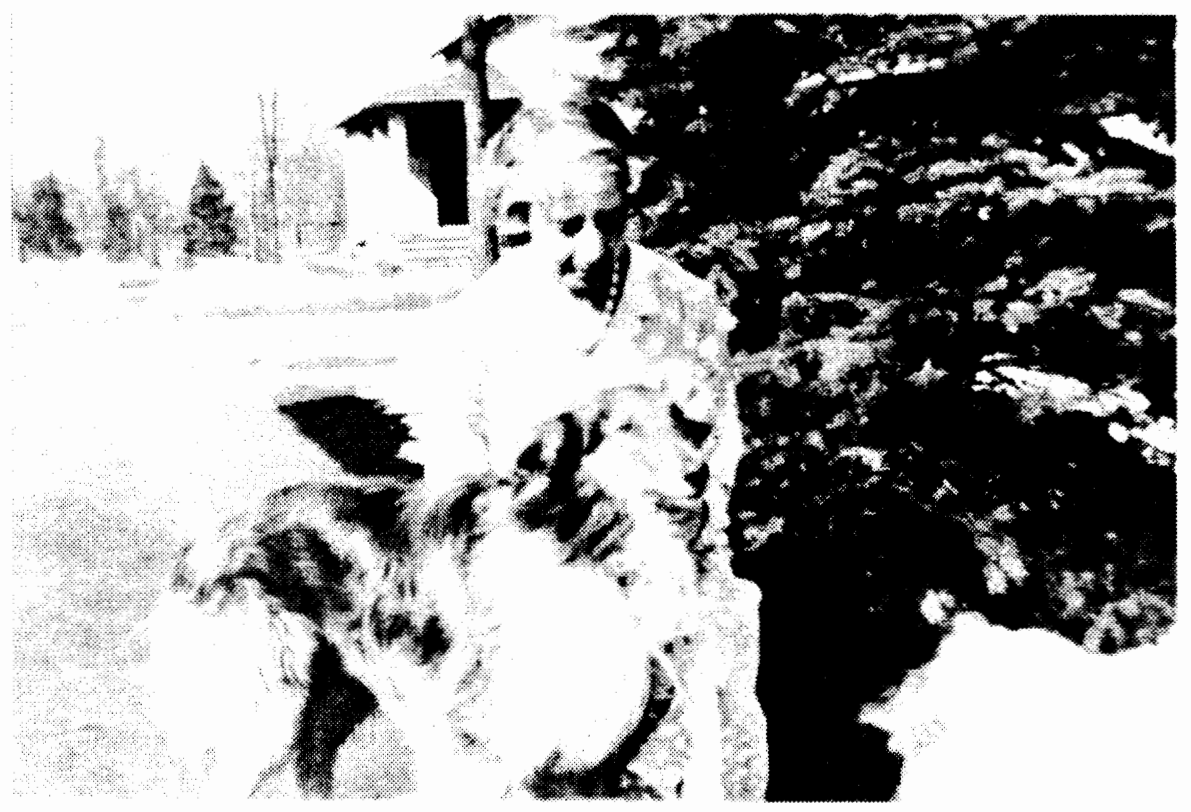

Alice and Max. Williamsville, New York, early to mid 1930s. Photo courtesy of Walden Pratt 


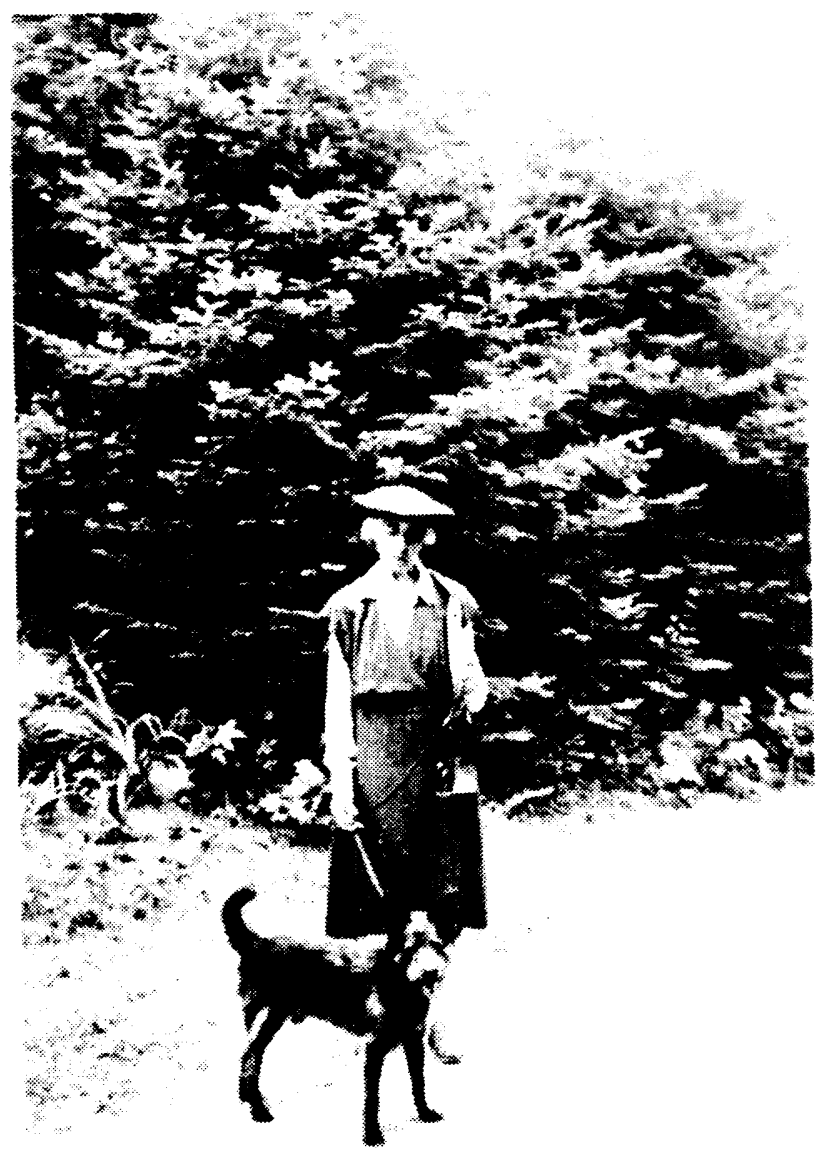

Alice and Tony near her trailer cabin at Old Forge, New York, late 1930s. Photo courtesy of Walden Pratt 


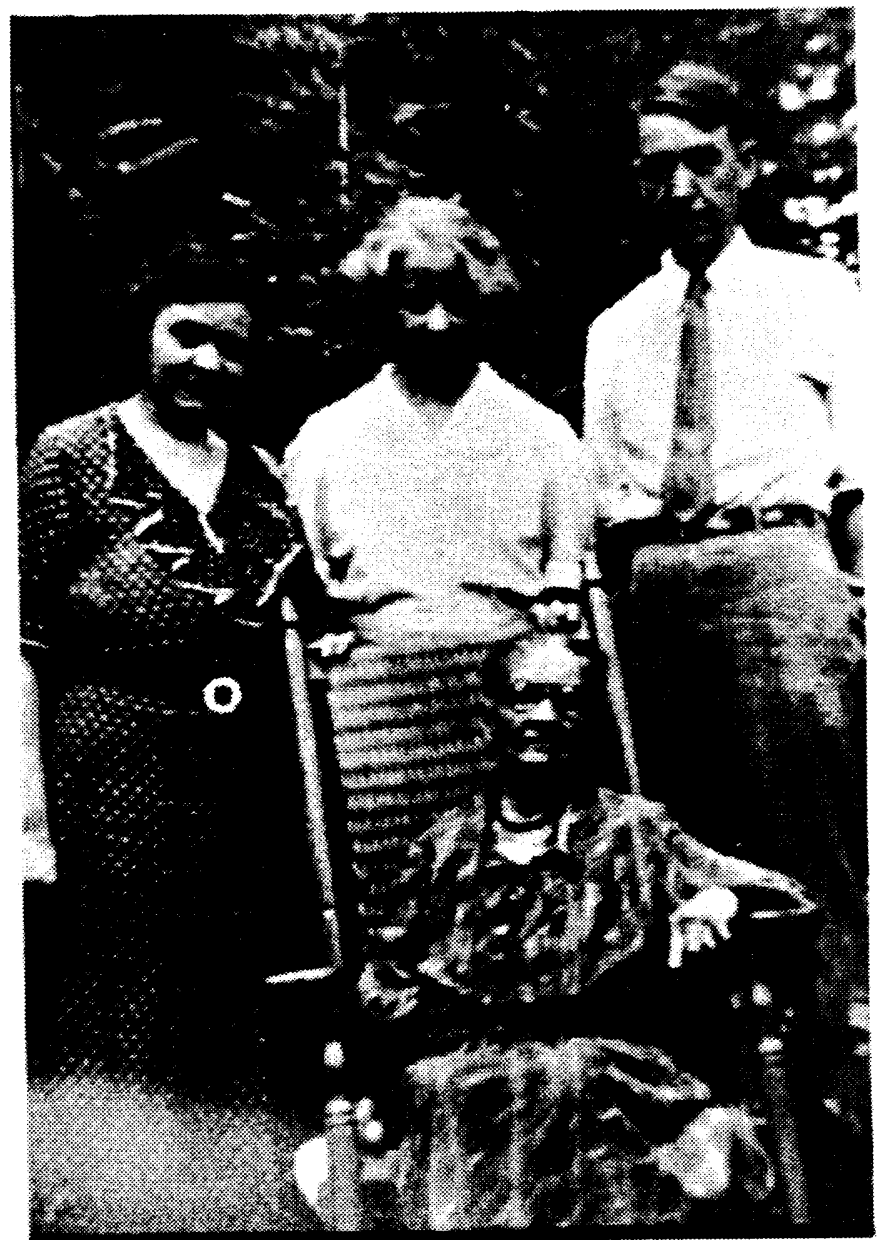

Marjorie, Alice, Julius and Sophie (seated). Old Forge, New York, 1937 or 1938 Courtesy of Crook County Historical Society 
Chapter 7

\section{Conclusion}

Alice Day Pratt had the same dream as many other Americans: to own a piece of land upon which one could earn a living and be independent. Societal attitudes towards women's roles and responsibilities were changing during her lifetime. Fortunately for Alice and numerous other women, it became more acceptable to be an educated single women supporting oneself. Like all homesteaders, and particularly women who had no spouse or family member to help with the arduous tasks of farming and ranching, she worked extremely hard and endured much. She cut two acres of hay with a knife. In addition to milking cows and feeding chickens, she stacked twenty-five tons of hay. "When the last load was on the last stack and I realized that I had made a crop from the hauling of seed to the last folding away of the last straw, I sat down beneath a haystack..." While seated she composed a poem entitled "The Making of Hay. ${ }^{1314}$ Before she had a horse she was her own beast of burden, able to carry forty pounds upon her back. She walked thirty miles to Prineville. She lost chickens to hawks and coyotes. She lost crops to jackrabbits. She endured long after other homesteader gave in. Ultimately, drought and the Depression were too much for her. Even though she left penniless in 1930, Alice still clung to the dream of returning to Broadview. Writing to friends in Prineville, from New York, where she lived with her mother (until her death)

\footnotetext{
${ }^{314}$ Pratt, Homesteader's Portfolio, 173
} 
and sister until her own death in 1963 at age ninety, she often mentioned her desire to return to Oregon.

Alice Day Pratt is an exception to the popular mythology of the West. There were other women in the region besides prostitutes and reluctant wives. Contrary to popular belief, the West is not a place of acceptance and freedom from class discrimination. As everywhere else, people who are unlike those of their community often encounter difficulty being accepted. Alice was different from many of the Prineville area residents. Her level of education and Eastern upbringing set her apart. She was a political liberal who campaigned for civil rights. She was a vegetarian. She could not tolerate killing animals. Alice experienced the animosity of cattle ranchers and local citizens who did not like homesteaders invading their region, especially single women. Unfortunately, some in the community could not or would not look beyond her peculiarities.

The West is not always a place for a new beginning. The fertile lands of the Willamette Valley, well watered by sufficient rainfall, were claimed more than a quarter of a century earlier. Alice, and thousands of others who came to Central Oregon attempted a new beginning as dry land farmers, yet, due to circumstances of nature and national economy, often beyond their control, they were unable to succeed.

One should not single out Alice as an heroic individual nor have pity on her because she "failed." She was one of many individuals who struggled to create an independent life. She symbolizes the hardships and joys of countless homesteaders. She also is representative of numerous single 
women, few of whom left written records of their experiences. These

women gained independence and self-confidence as they worked to fulfill a

dream. Looking back at her interesting life, Alice wrote,

Now, in 1953, I would add this word that experience has made clear to me: Success may be the smallest and least important of the fruits of endeavor; it is the endeavor itself, the opportunity to use one's whole self completely -- initiative, creativity, and physical strength -- that is its own reward; and it may well be that one looks back upon the times of greatest strain and anxiety as the high points in his pilgrimage. ${ }^{315}$ 


\section{BIBLIOGRAPHY}

\section{PRIMARY SOURCES}

Advantages of Oregon: A Resource Book. Portland: privately printed, n.d.

Bern, Enid, ed. "They Had a Wonderful Time: The Homesteading Letters of Anna and Ethel Erickson." North Dakota History 45 (1978): 4-31.

Campbell, H.W. Campbell's 1905 Soil Culture Manual. Lincoln, Nebraska: H.W. Campbell, 1905.

Corey, Elizabeth. Bachelor Bess: The Homesteading Letters of Elizabeth Corey, 1909-1919. Edited by Philip L. Gerber. With foreward by Paul Corey and afterward by Wayne Franklin. Iowa City: University of lowa Press, 1990.

Coe, Urling C. Frontier Doctor: Observations on Central Oregon and the Changing West. With an introduction by Robert Bunting. New York: Macmillan,1940, reprint Corvallis: Oregon State University Press, 1996.

Keetley, Dawn and John Pettegrew, eds. Public Women, Public Words: $A$ Documentary History of American Feminism. Vol. 1, Beginnings to 1900. Madison, WI.: Madison House, 1997.

Keisling, Phil, comp. and ed. Oregon Blue Book, 1997-1998. Salem, 1997.

Kohl, Edith Eudora. Land of the Burnt Thigh. With an introduction by Glenda Riley. St. Paul: Minnesota Historical Society Press, 1986.

O'Callaghan, Jerry A. The Disposition of the Public Domain in Oregon. 86th Cong., 2d sess., 1960. Washington , DC: Government Printing Office, 1960

Pratt, Alice Day. A Homesteader's Portfolio. With an introduction by Molly Gloss. New York: Macmillan,1922, reprint Corvallis: Oregon State University Press, 1993.

. Animal Babies. Boston: Beacon Press, 1941, revised 1959.

. Animals of a Sagebrush Ranch. New York: Rand McNally and Company, 1931. 
575-6.

"Feathered Affection." The Atlantic Monthly 115 (June, 1915):

423.

"Heritage." Sunset, the Pacific Monthly 34 (March, 1915):

. "Hippos." The Atlantic Monthly 147 (June, 1931): 737-43.

309-15.

"I Take to the Woods." The Atlantic Monthly 150 (Sept., 1932):

. "Jerseys." The Atlantic Monthly 147 (Jan., 1931): 52-59.

. "Song of the Homesteaders." Sunset, the Pacific Monthly 31

(August, 1913): 327.

. Three Frontiers. New York: Vantage Press, 1955.

"White Leghorns." The Atlantic Monthly 118 (July, 1916): 141-42.

Pratt v. Gibson. Supreme Court of the State of Oregon, 1916.

Pratt v. Gibson. Circuit Court of the State of Oregon, 1916.

Pratt v. Gibson. District Court No. 22 of Crook County, 1916.

Shih, Hu and Lin Yutang. China's Own Critics: A Selection of Essays. With Commentaries by Wang Ching-Wei. New York: Paragon Book Reprint Corp., 1969.

Snell, Joseph W., ed. "Roughing it on her Kansas Claim: The Diary of Abbie Bright, 1870-1871." The Kansas Historical Quarterly 37 (Autumn, 1971): 233-268 and 37 (Winter, 1971): 394-428.

U.S. Department of Commerce. Census of Population: General Characteristics. Washington DC: U.S. Government Printing Office, June 1992.

U.S. Department of Commerce. Census of Population: General Characteristics of Oregon. Washington DC: U.S. Government Printing Office, June 1992.

Wolverton, Beverly A. A Hundred and Sixty Acres in the Sage: A Homestead History of the Immediate Post Area. Post, OR: by the author, 1984. 
Yutang, Lin. My Country and My People. New York: Halcyon House, 1938.

\section{UNPUBLISHED SOURCES}

Pratt, Alice Day. Letters to friends in Prineville, Oregon spanning the years 20 February 1926 to December 1962. Crook County Historical Society, Prineville, Oregon.

Pratt, Alice Day. Letters to family members written between 28 June 1936 to 5 March 1956. Photocopies of originals in the possession of William Pratt, State College, Pennsylvania.

Letters to Alice Day Pratt from her mother, her father, her sister, her brother, her sister-in-law written, and The Macmillan Company between 8 December 1912 to 30 January 1926. Crook County Historical Society, Prineville, Oregon.

Pratt, Alice Day. Teacher's Trek. Transcript of original in the possession of Walden Pratt, Arvada, Colorado.

Ragen, Brooks. Alice Day Pratt in Oregon. Transcript of original in the possession of Brooks, Ragen, Seattle, Washington.

\section{INTERVIEWS}

Brummer, Don and Maxine. Interview by author, 22 July 1995 at their home, Prineville, Oregon.

Bushnel, Francis. Interview by author, 22 July 1995 at the home of Don and Maxine Brummer, Prineville, Oregon.

Gillmor, Flora. Interview by author, 22 July 1995 at the home of Don and Maxine Brummer, Prineville, Oregon.

Wilson Mary Demaris . Interview by author, 21 July 1995 at Crook County Historical Society, Prineville, Oregon.

Wolverton, Beverly. Interview by author 22 July 1995 at the home of Don and Maxine Brummer, Prineville, Oregon. 


\section{NEWSPAPERS}

Bend Bulletin, 7 Sept. 1910, 25 Jan. 1911, 24 April 1912, 3 July 1913.

Crook County Journal (Prineville, Oregon), 16 Dec., 1915, 9 March 1916, 7 March 1917.

Central Oregonian (Prineville, Oregon), 10 Feb., 1925.

Silver, Clarine. "Alice Day Pratt, Early Homesteader at Post, wrote of harshness, challenge of life on the high desert," High Country, 10 February 1973.

Silver, Clarine. "The Old Maid of Friar Butte," Register-Guard Emerald Empire, (Eugene, Oregon), 23 April 1972.

\section{SECONDARY SOURCES}

\section{BOOKS}

Allen, Barbara. Homesteading the High Desert. Salt Lake City: University of Utah Press, 1987.

Brogan, Phil F. East of the Cascades. Edited by L.K. Phillips. Portland, OR.: Binfords and Mort, 1964.

Bowman, Isaiah. The Pioneer Fringe. Freeport, NY: Books for Libraries Press, 1931; reprint 1971.

Chambers-Schiller, Lee Virginia. Liberty, A Better Husband. New Haven: Yale University Press, 1984.

Cott, Nancy F. The Bonds of Womanhood: "Woman's Sphere in New England, 1780-1835." New Haven: Yale University Press, 1977.

Crook County Historical Society. The History of Crook County, Oregon.

Prineville, OR.: Crook County Historical Society, 1981.

Foner, Eric. Free Soil, Free Labor, Free Men: The Ideology of the Republican Party Before the Civil War. New York: Oxford University Press, 1970. 
Gates, Paul W. History of Public Land Law Development. Washington, DC: $\quad$ Public Land Law Commission, 1968.

Hampsten, Elizabeth. Read This Only to Yourself: The Private Writings of Midwestern Women. Bloomington: Indiana Press, 1982.

Hatton, Raymond. Pioneer Homesteaders of the Fort Rock Valley. Portland: Binford and Mort, 1982.

Jackman, E.R. and R.A. Long. The Oregon Desert. Caldwell, ID.: The Claxton Printers, Ltd., 1973.

Jensen, Joan. With These Hands: Women Working the Land. Old Westbury, NY: The Feminist Press, 1981.

Johansen, Dorothy. "The Role of Land Laws in the Settlement of Oregon," in Genealogical Material in Oregon Donation Land Claims Vol. I. Portland: Genealogical Forum, 1957.

Kaufman, Polly Welts. Women Teachers on the Frontier. New Haven: Yale University Press, 1984.

. "A Wider Field of Usefulness: Pioneer Women Teachers in the West 1848-54." In Women in the West, ed. Glenda Riley, 16-25. Manhattan, Kansas: Sunflower University Press, 1982.

Kerber, Linda K. and Jane Sherron DeHart, ed. Women's America:

Refocusing the Past. $3^{\text {rd }}$ ed. New York: Oxford University Press, 1991.

Lippy Charles H. and Peter W. Williams, eds. Encyclopedia of the American Religious Experience: Studies of Traditions and Movements, Vol.I. New York: Charles Scribner's Sons, 1988. 589-90.

Malone, Michael. James J. Hill: Empire Builder of the Northwest. Norman: University of Oklahoma Press, 1996.

McArthur, Lewis L. Oregon Geographic Names. $6^{\text {th }}$ ed. Portland: Oregon Historical Society Press, 1992.

Marty, Martin E. Modern American Religion: The Irony of It All 1893-1919. Chicago: The University of Chicago Press, 1986. 276-279.

. Modern American Religion: The Noise of Conflict 1919-1941.

Chicago: The University of Chicago Press, 1991 
Marx, Leo. The Machine in the Garden: Technology and the Pastoral Ideal in America. New York: Oxford University Press, 1964.

Merk, Frederick. Manifest Destiny and Mission in American History. With a foreward by John Mack Faragher. Cambridge: Harvard University Press, 1995.

Meyers, Sandra L. Westering Women and the Frontier Experience 18001915. Albuquerque: University of New Mexico Press, 1982.

Richards, Kent D. Issac I. Stevens: Young Man in a Hurry. Provo, Utah: Bringham Young University Press, 1979.

Riley, Glenda. Frontierswomen: The lowa Experience. Ames: lowa State University Press, 1981.

Schwantes, Carlos. Railroad Signatures Across the Pacific Northwest. Seattle: University of Washington Press, 1993. 132-147.

Sklar, Kathryn Kish. Catharine Beecher: A Study in Domesticity. New Haven: Yale University Press, 1973.

Smith, Henry Nash. Virgin Land: The American West as Symbol and Myth. Cambridge: Harvard University Press, 1978.

State of Oregon. An Illustrated History of Central Oregon Embracing Wasco, Sherman, Gilliam, Wheeler, Crook, Lake, and Klamath Counties. Part VI: History of Crook County. Spokane, WA.: Western Historical Publishing Co., 1905.

Wollaston, Percy. A Montana Family Album. With a foreward by Jonathan Rabin. New York: The Lyons Press, 1997.

Wyman, Walker D. Frontier Woman: The Life of a Woman Homesteader on the Dakota Frontier. River Falls: University of Wisconsin-River Falls Press, 1972.

JOURNALS

Bauman, Paula M. "Single Women Homesteaders in Wyoming, 1880-1930," Annuals of Wyoming 58 (Spring 1986): 39-49. 
Hargreaves, Mary. "Homesteading and Homemaking on the Plains: A Review," Agricultural History 47 (1993): 165-163.

"Women in the Agricultural Settlement of the Northern Plains," Agricultural History 1 (Jan 1976): 179-189.

Meredith, Virginia C. “Women Farmers," Breeder's Gazette 67 (1915): 85354.

Nelson, Paula M. "'Do Everything' - Women in Small Prairie Towns, 1870 1920," Journal of the West 4 (October 1997): 52-60.

Riley, Glenda. "Farm Woman's Role in the Agricultural Development of South Dakota," South Dakota History 13 (1982): 83-98.

. "Images of the Frontierswoman: lowa as a Case Study," Western Historical Quarterly 8 (April 1977): 189-202.

"Women in the West," Journal of American Culture 3 (Summer 1980): 311-329.

Smith, Sherry L. "Single Women Homesteaders: The Perplexing Case of Elinore Pruitt Stewart," The Western Historical Quarterly 22 (May 1991): 163-183.

Sochen, June. "Frontier Women: A Model for All Women?" South Dakota History 7 (1976): 37-60.

Webb, Anne B. "Forgotten Persephones," Minnesota History 50 (Winter 1986): $138-148$.

"Minnesota Women Homesteaders: 1863-1889," Journal of Social History 23 (Fall 1989): 115-136.

Wert, Lynette. "The Lady Stakes a Claim," Persimmon Hill 6 (1976): 18-23.

Willingham, William $\mathrm{H}$. "Family and Community on the Eastern Oregon Frontier," Oregon Historical Quarterly, 95 (Summer 1994): 176-204. 